\title{
Annual Report on U.S. Manufacturing Industry Statistics: 2021
}

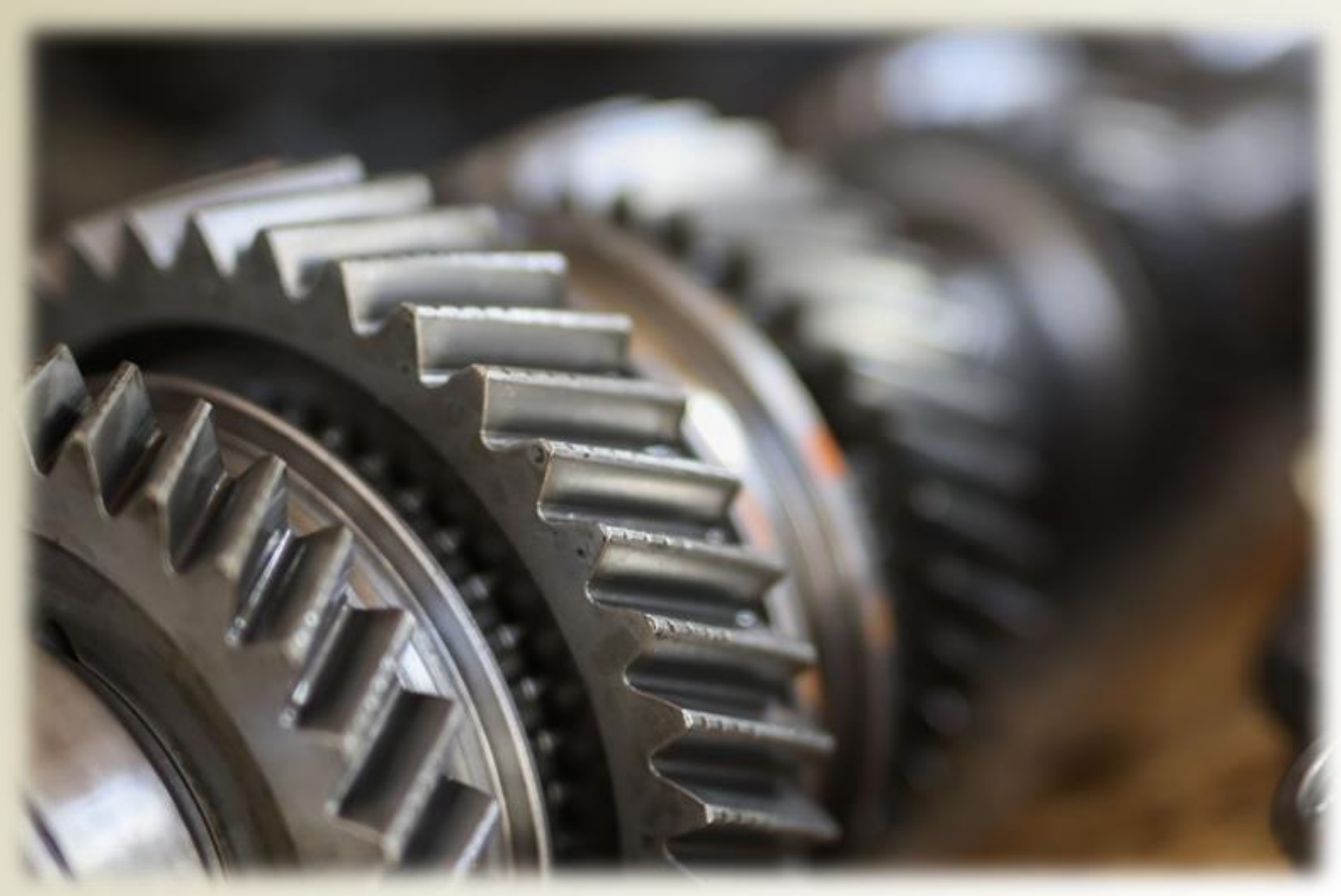

An examination of how U.S. manufacturing compares to other countries, the trends in the domestic industry, and the industry trends compared to those in other countries.

Douglas S. Thomas

This publication is available free of charge from: https://doi.org/10.6028/NIST.AMS.100-42

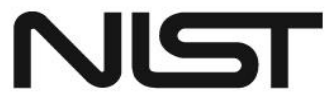

National Institute of Standards and Technology U.S. Department of Commerce 


\title{
Annual Report on Manufacturing Industry Statistics: 2021
}

\author{
Douglas S. Thomas \\ Applied Economics Office \\ Engineering Laboratory
}

This publication is available free of charge from:

https://doi.org/10.6028/NIST.AMS.100-42

October 2021

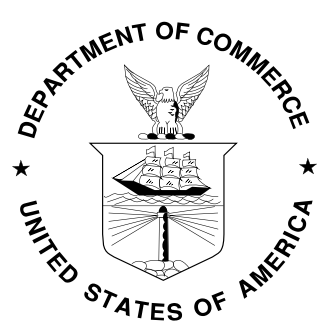

U.S. Department of Commerce Gina M. Raimondo, Secretary

National Institute of Standards and Technology

James K. Olthoff, Performing the Non-Exclusive Functions and Duties of the Under Secretary of Commerce for Standards and Technology \& Director, National Institute of Standards and Technology 
Certain commercial entities, equipment, or materials may be identified in this document in order to describe an experimental procedure or concept adequately. Such identification is not intended to imply recommendation or endorsement by the National Institute of Standards and Technology, nor is it intended to imply that the entities, materials, or equipment are necessarily the best available for the purpose.

National Institute of Standards and Technology Advanced Manufacturing Series 100-42

Natl. Inst. Stand. Technol. Adv. Man. Ser. 100-42, 59 pages (October 2021)

This publication is available free of charge from: https://doi.org/10.6028/NIST.AMS.100-42 


\section{Preface}

This study was conducted by the Applied Economics Office (AEO) in the Engineering Laboratory (EL) at the National Institute of Standards and Technology (NIST). The study provides aggregate manufacturing industry data and industry subsector data to develop a quantitative depiction of the U.S. manufacturing industry.

\section{Disclaimer}

Certain trade names and company products are mentioned in the text in order to adequately specify the technical procedures and equipment used. In no case does such identification imply recommendation or endorsement by the National Institute of Standards and Technology, nor does it imply that the products are necessarily the best available for the purpose. 


\section{Table of Contents}

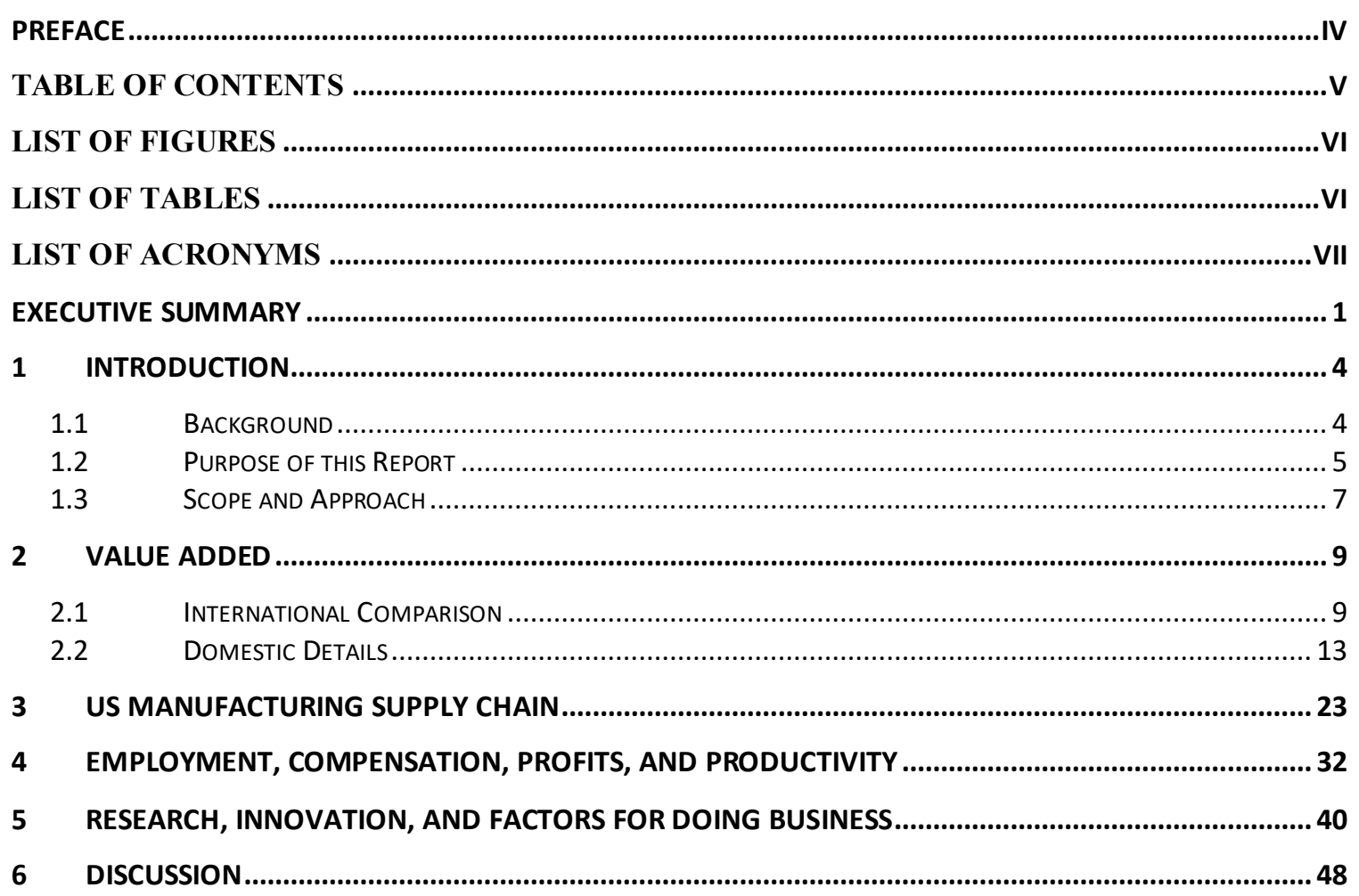




\section{List of Figures}

Figure 1.1: Illustration of Objectives - Drive Inputs and Negative Externalities Down while Increasing Production Output and Product Function

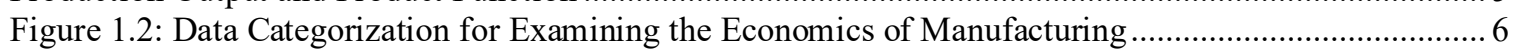

Figure 1.3: Illustration of the Feasibility of Data Collection and Availability ...........................................8

Figure 2.1: National 25-Year Compound Annual Growth, by Country (1994 to 2019): Higher is Better... 10

Figure 2.2: National 5-Year Compound Annual Growth, by Country (2014 to 2019): Higher is Better..... 10

Figure 2.3: Manufacturing Value Added, Top 10 Manufacturing Countries (1970 to 2019)..................... 11

Figure 2.4: Manufacturing Value Added Per Capita, Top 10 Largest Manufacturing Countries (1970 to

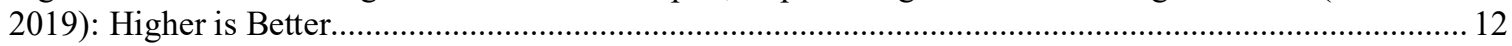

Figure 2.5: Manufacturing Per Capita Ranking, 1970-2019: Lower is Better.......................................... 12

Figure 2.6: Global Manufacturing Value Added by Industry, Top Five Producers and Rest of World (ROW)

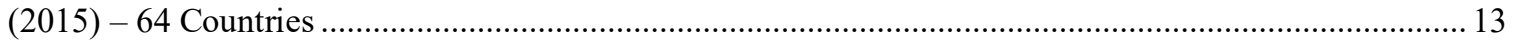

Figure 2.7: Cumulative Percent Change in Value Added (2012 Chained Dollars) .................................. 14

Figure 2.8: Value Added for Durable Goods by Type (billions of chained dollars), 2005-2020 ............... 15

Figure 2.9: Value Added for Nondurable Goods by Type (billions of chained dollars), 2005-2020: Higher is

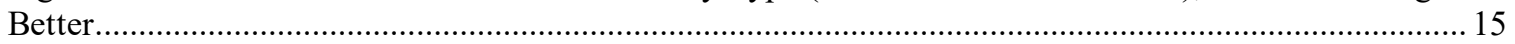

Figure 2.10: Manufacturing Value Added by Subsector (billions of chained dollars) .............................. 16

Figure 2.11: Value Added for Durable Goods by Type (constant dollars), 2005-2020 ............................. 17

Figure 2.12: Value Added for Nondurable Goods by Type (constant dollars, billions), 2005-2020 .......... 17

Figure 2.13: Manufacturing Value Added by Subsector, BEA (constant dollars, billions), 2005-2020 ...... 18

Figure 2.14: Current-Cost Net Stock: Private Equipment, Manufacturing (2005-2020).......................... 19

Figure 2.15: Current-Cost Net Stock: Private Structures, Manufacturing (2005-2020)............................ 20

Figure 2.16: Current-Cost Net Stock: Intellectual Property Products, Manufacturing (2005-2020)............ 21

Figure 2.17: Current-Cost Net Stock in Manufacturing, by Type (2005-2020) .....................................22

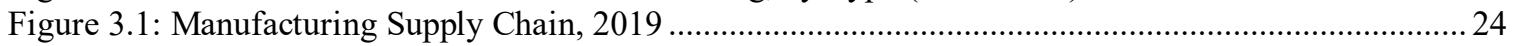

Figure 3.2 Expenditures by Subsector, Annual Survey of Manufactures............................................. 31

Figure 4.1: Cumulative Change in Percent in Manufacturing Employment (Seasonally Adjusted) and

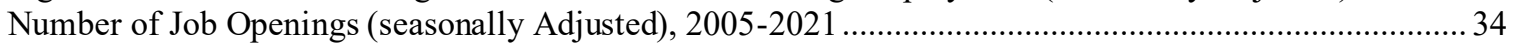

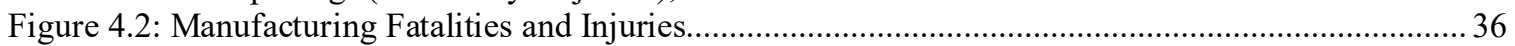

Figure 4.3: Average Weekly Hours for All Employees (Seasonally Adjusted) ........................................36

Figure 4.4: Average Hourly Wages for Manufacturing and Private Industry (Seasonally Adjusted) ...........37

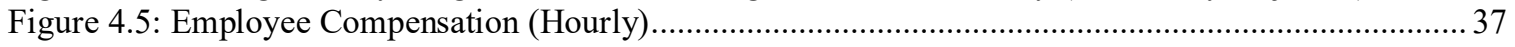

Figure 4.6: Profits for Corporations and Income for Proprietorships ................................................ 38

Figure 4.7: Manufacturing Labor Productivity Index (2012 Base Year = 100) .........................................38

Figure 4.8: Manufacturing Multifactor Productivity Index (2012 Base Year = 100)................................39

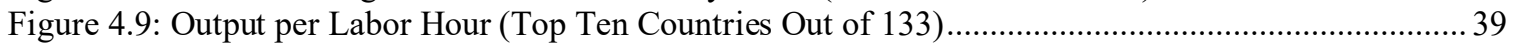

Figure 5.1: Patent Applications (Residents) per Million People, Top Ten (1990-2019)............................40

Figure 5.2: Research and Development Expenditures as a Percent of GDP ......................................... 41

Figure 5.3: Manufacturing Enterprise Research and Development Expenditures ................................... 41

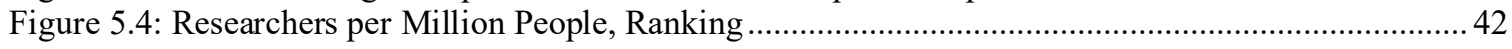

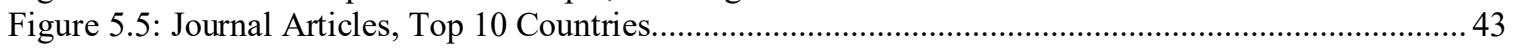

Figure 5.6: Goods Exports (BOP) of the Top Ten Exporters ...............................................................43

Figure 5.7: IMD World Competitiveness Rankings for the US: Lower is Better (i.e., a Rank of 1 is Better

than a Rank of 64) - 64 countries ranked

Figure 5.8: World Economic Forum 2019 Global Competitiveness Index: U.S. Pillar Rankings: Lower is

Better.

Figure 5.9: Factors Impacting U.S. Business (Annual Survey of Entrepreneurs), 2016.

\section{List of Tables}

Table 3.1: Supply Chain Entities and Contributions, Annual Survey of Manufactures, 2019 ...................23

Table 3.2: Direct and Indirect Manufacturing Value Added ................................................................ 25

Table 3.3: Imported Intermediate Manufacturing (\$millions). 
Table 3.4: Percent of U.S. Manufacturing Industry Supply Chain, by Country of Origin (2014) ...............22

Table 3.5: Depreciable Assets and the Rate of Change, 2017 (\$million 2017).........................................2 27

Table 3.6: Top $20 \%$ of Domestic Supply Chain Entities, Value Added..................................................29

Table 3.7: Total Domestic Compensation for Manufacturing and its Supply Chain, by Occupation ........... 30

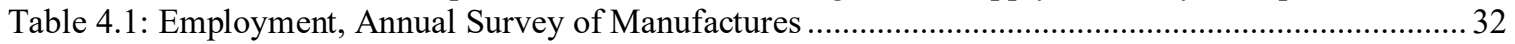

Table 4.2: Employment by Industry for 2018 and 2019 (Thousands): Current Population Survey ….......... 33

Table 4.3: Manufacturing Employment (Thousands): Current Employment Statistics.............................. 33

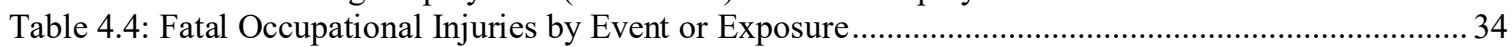

Table 4.5: Total Recordable Cases of Nonfatal Injuries and Illnesses Involving Days Away from Work... 35

Table 5.1: World Economic Forum Competitiveness Index Indicators - Selection of those Relevant to

Standards, Technology, and Information Dissemination Solutions, Rankings Out of 141 Countries (Lower

is Better).

Table 5.2: Rankings from the Competitive Industrial Performance Index 2019, 152 Total Countries

\title{
List of Acronyms
}

\author{
ASE: Annual Survey of Entrepreneurs \\ ASM: Annual Survey of Manufactures \\ BEA: Bureau of Economic Analysis \\ GDP: Gross Domestic Product \\ IBRD: International Bank for Reconstruction and Development \\ IDA: International Development Association \\ ISIC: International Standard Industrial Classification \\ MAPI: Manufacturers Alliance for Productivity and Innovation \\ NAICS: North American Industry Classification System \\ NIST: National Institute of Standards and Technology \\ PPP: Purchasing Power Parity \\ SIC: Standard Industrial Classification \\ UNSD: United Nations Statistics Division
}




\section{Executive Summary}

This report provides a statistical review of the U.S. manufacturing industry. There are three aspects of U.S. manufacturing that are considered: (1) how the U.S. industry compares to other countries, (2) the trends in the domestic industry, and (3) the industry trends compared to those in other countries. The U.S. remains a major manufacturing nation; however, other countries are rising rapidly. Manufacturing in the U.S. was significantly impacted by the pandemic of the Coronavirus Disease 2019 (COVID-19).

Although U.S. manufacturing performs well in many respects, there are opportunities for advancing competitiveness. This will require strategic placement of resources to ensure that U.S. investments have the highest return possible.

Competitiveness - Manufacturing Industry Size: In 2020, U.S. manufacturing accounted for $\$ 2269.2$ billion in value added or $10.8 \%$ of GDP, according to BEA data. Direct and indirect (i.e., purchases from other industries) manufacturing accounts for $24.1 \%$ of GDP. China was the largest manufacturing nation, producing $29.4 \%$ of global manufacturing value added while the U.S. was the second largest, producing $16.6 \%$, according to the United Nations Statistics Division data. Among the ten largest manufacturing countries, the U.S. is the $4^{\text {th }}$ largest manufacturing value added per capita (see Figure 2.4) and out of all countries the most recent U.S. rank is $14^{\text {th }}$, as illustrated in Figure 2.5. The U.S. ranks $1^{\text {st }}$ in 7 manufacturing industries out of 16 total, while China was the largest for the other industries, as seen in Figure 2.6.

Competitiveness - Manufacturing Growth: Compound real (i.e., controlling for inflation) annual growth in the U.S. between 1994 and 2019 (i.e., 25-year growth) was $2.4 \%$, which places the U.S. below the $50^{\text {th }}$ percentile. The compound annual growth for the U.S. between 2014 and 2019 (i.e., 5-year growth) was $1.9 \%$. This puts the U.S. just above the $25^{\text {th }}$ percentile above Canada and Germany among others.

Competitiveness - Productivity: Labor productivity for manufacturing decreased slightly from 2019 to 2020, as illustrated in Figure 4.7. The five-year compound annual growth is $-0.4 \%$. For U.S. manufacturing, multifactor productivity decreased $2.0 \%$ from 2019 to 2020 and has a 5-year compound annual growth rate of $-0.8 \%$, as illustrated in Figure 4.8. Productivity in the U.S. is relatively high compared to other countries. As illustrated in Figure 4.9, the U.S. is ranked seventh in output per hour among 133 countries using data from the Conference Board. In recent years, productivity growth has been negative or has come to a plateau in many countries and the U.S. seems to be following this pattern of slow growth. There are competing explanations for why productivity has slowed, such as an aging population, inequality, or other factors. A number of the explanations equate to low levels of capital investment. It is also important to note that productivity is difficult to measure and even more difficult to compare across countries. Moreover, the evidence does not seem to support any particular explanation over another as to why productivity appears to have stalled. 
Competitiveness - Economic Environment: There is no agreed upon measure for research, innovation, and other factors for doing business, but there are a number of common measures that are used. The ranking of the U.S. in these measures has mixed results, ranking high in some and lower in others. For instance, the U.S. ranks $4^{\text {th }}$ in patent applications per million people but ranks $19^{\text {th }}$ in researchers per capita and $22^{\text {nd }}$ in journal article publications per capita. The IMD World Competitiveness Index, which measures competitiveness for conducting business, ranked the U.S. $10^{\text {th }}$ in competitiveness for conducting business and the World Economic Forum, which assesses the competitiveness in determining productivity, ranked the U.S. $2^{\text {nd }}$. Note that neither of these are specific to manufacturing, though. A third index specific to manufacturing, the Deloitte Global Manufacturing Index, ranks China $1^{\text {st }}$ and the U.S. $2^{\text {nd }}$. The Competitive Industrial Performance Index, which measures capacity to produce and export manufactured goods; technological deepening and upgrading; and world impact, ranked the U.S. as $3^{\text {rd }}$.

Domestic Specifics - Types of Goods Produced: The largest manufacturing subsector in the U.S. is chemical manufacturing, followed by computer and electronic products and food, beverage, and tobacco products, as seen in Figure 2.13. Discrete technology products accounted for $36 \%$ of U.S. manufacturing.

Domestic Specifics - Economic Disruptions: Manufacturing in the U.S. declined significantly in 2008 and only recently returned to its pre-recession peak level in 2017. Manufacturing value added declined more than total U.S. GDP, creating a persistent gap. The result is that first quarter GDP in 2021 is $29.2 \%$ above its 2005 level while manufacturing is at $21.5 \%$ above its 2005 level. As of January 2020, employment was still $10.3 \%$ below its 2005 level. During 2020, as a result of the pandemic manufacturing employment declined to $19.9 \%$ below 2005 levels, which is near the same levels as the late 2000's recession. Between 2019 and 2020, manufacturing employment declined $5.0 \%$, according to the Current Employment Statistics. Following the $4^{\text {th }}$ quarter of 2019 , total GDP declined $10.1 \%$ and manufacturing value added declined $12.2 \%$. Despite lower employment levels, there are a substantial number of job openings in manufacturing. If these openings were filled, it would raise employment above prepandemic levels and would equate to a $7 \%$ increase in manufacturing employment.

Domestic Specifics - Manufacturing Supply Chain Costs: High-cost supply chain industries/activities, which might pose as opportunities for advancing competitiveness, include various forms of energy production and/or transmission, various forms of transportation, the management of companies and enterprises among other items listed in Table 3.6.

Domestic Specifics - Manufacturing Safety, Compensation, and Profits: As illustrated in Figure 4.5, employee compensation in manufacturing, which includes benefits, has had a five-year compound annual growth of $-1.2 \%$. In terms of safety in manufacturing, fatalities, injuries, and the injury rate have had an overall downward trend since 2002, as seen in Figure 4.2. However, the incident rate for nonfatal injuries in manufacturing remains higher than that for all private industry. 
For those that invest in manufacturing, nonfarm proprietors' income for manufacturing has had a five-year compound annual growth rate of $-4.3 \%$, as illustrated in Figure 4.6. Corporate profits have had a five-year compound annual growth of $-5.8 \%$. 


\section{Introduction}

\subsection{Background}

Public entities have a significant role in the U.S. innovation process. ${ }^{1}$ The federal government has had a substantial impact in developing, supporting, and nurturing numerous innovations and industries, including the Internet, telecommunications, aerospace, semiconductors, computers, pharmaceuticals, and nuclear power among others, many of which may not have come to fruition without public support. ${ }^{2}$ Although the Defense Advanced Research Projects Agency (DARPA), Small Business Innovation Research Program (SBIR), and Advanced Technology Program (ATP) have received attention in the scholarly community, there is generally limited awareness of the government's role in U.S. innovation. The vastness and diversity of U.S. federal research and development programs along with their changing nature make them difficult to categorize and evaluate, ${ }^{3}$ but their impact is often significant. For instance, the origins of Google are rooted in a public grant through the National Science Foundation. ${ }^{4}{ }^{5}$ One objective of public innovation is to enhance economic security and improve our quality of life ${ }^{6}$, which is achieved in part by advancing efficiency in which resources are consumed or impacted by production. This includes decreasing inputs, which amount to costs, and negative externalities (e.g., environmental impacts) while increasing output, (i.e., the products produced), and the function of the product (e.g., the usefulness of the product), as seen in Figure 1.1. In pursuit of this goal, the National Institute of Standards and Technology (NIST) has expended resources on a number of projects, such as support for the development of the International Standard for the Exchange of Product Model Data (STEP), ${ }^{7}$ which reduces the need for duplicative efforts such as re-entering design data. Another effort to advance efficiency is the development of the Core Manufacturing Simulation Data (CMSD) specification, which enables data exchange for manufacturing simulations. ${ }^{8}$

\footnotetext{
${ }^{1}$ Block, Fred L and Matthew R. Keller. State of Innovation: The U.S. Government's Role in Technology Development. New York, NY; Taylor \& Francis; 2016.

${ }^{2}$ Wessner CW and Wolff AW. Rising to the Challenge: U.S. Innovation Policy for the Global Economy. National Research Council (US) Committee on Comparative National Innovation Policies: Best Practice for the 21st Century. Washington (DC): National Academies Press (US). 2012.

http://www.ncbi.nlm.nih.gov/books/NBK100307/

${ }^{3}$ Block, Fred L and Matthew R. Keller. State of Innovation: The U.S. Government's Role in Technology

Development. New York, NY; Taylor \& Francis; 2016. 27.

${ }^{4}$ National Science Foundation. (2004). "On the Origins of Google."

https://www.nsf.gov/discoveries/disc_summ.jsp?cntn_id=100660

${ }^{5}$ Block, Fred L and Matthew R. Keller. State of Innovation: The U.S. Government's Role in Technology

Development. New York, NY; Taylor \& Francis; 2016: 23.

${ }^{6}$ National Institute of Standards and Technology. (2018). "NIST General Information."

http://www.nist.gov/public_affairs/general_information.cfm

${ }^{7}$ Robert D. Niehaus, Inc. (2014). Reassessing the Economic Impacts of the International Standard for the Exchange of Product Model Data (STEP) on the U.S. Transportation Equipment Manufacturing Industry. November 26, 2014. Contract SB1341-12-CN-0084.

${ }^{8}$ Lee, Yung-Tsun Tina, Frank H. Riddick, and Björn Johan Ingemar Hohansson (2011). "Core

Manufacturing Simulation Data - A Manufacturing Simulation Integration Standard: Overview and Case Studies." International Journal of Computer Integrated Manufacturing. vol 24 issue 8: 689-709.
} 


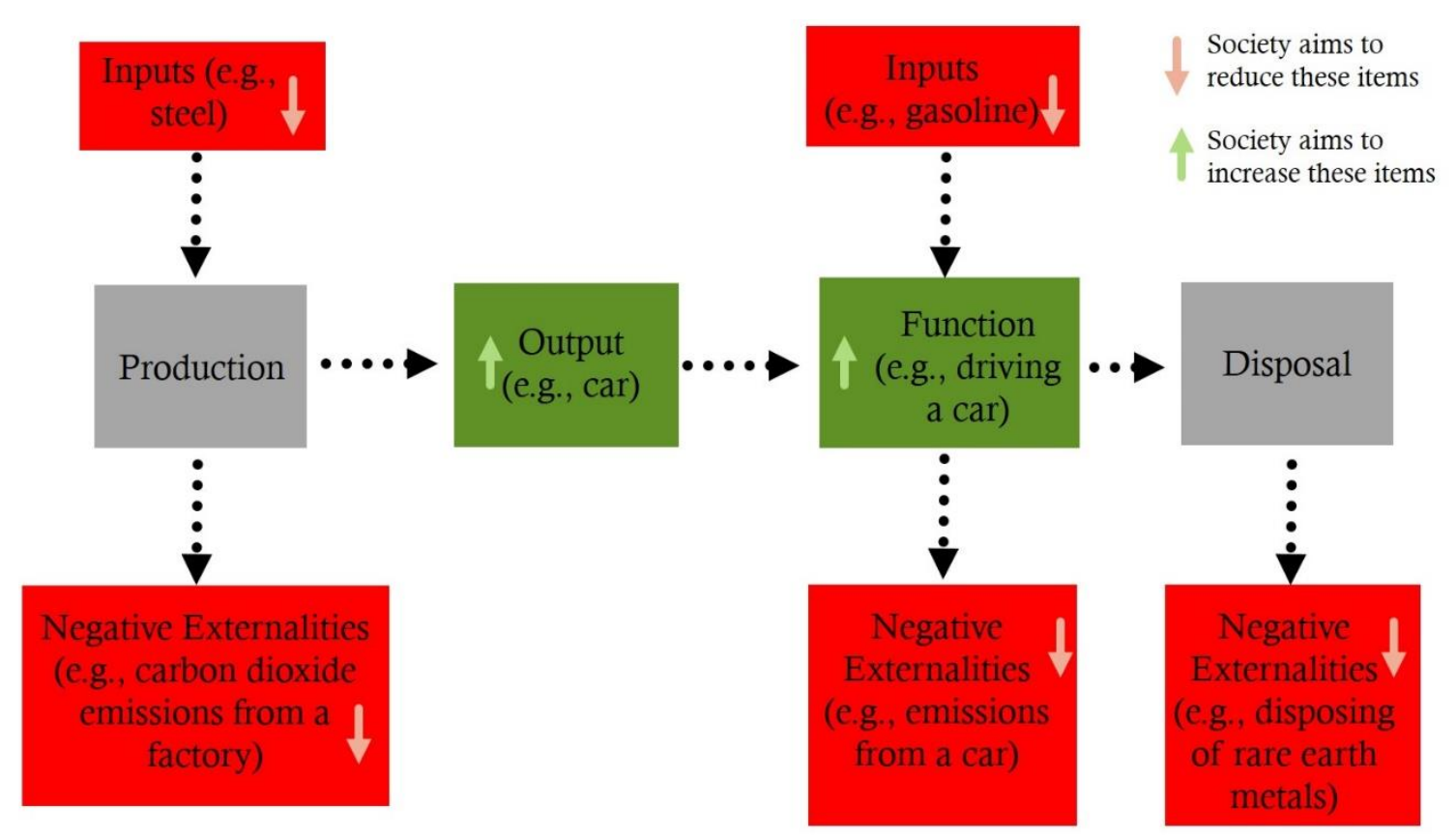

Figure 1.1: Illustration of Objectives - Drive Inputs and Negative Externalities Down while Increasing Production Output and Product Function

\subsection{Purpose of this Report}

The purpose of this report is to characterize U.S. innovation and industrial competitiveness in manufacturing, as it relates to the objectives illustrated in Figure 1.1. It includes tracking domestic manufacturing activity and its supply chain in order to develop a quantitative depiction of U.S. manufacturing in the context of the domestic economy and global industry. There are five aspects that encapsulate the information discussed in this report:

- Growth and Size: The size of the U.S. manufacturing industry and its growth rate as compared to other countries reveals the relative competitiveness of the industry.

○ Metrics: Value added, value added per capita, assets, and compound annual growth

- Productivity: It is necessary to use resources efficiently to have a competitive manufacturing industry. Productivity is a major driver of the growth and size of the industry.

○ Metrics: Labor productivity index, multifactor productivity index, output per hour

- Economic Environment: A number of factors, including research, policies, and societal trends, can affect the productivity and size of the industry. 
- Metrics: Research and development expenditures as a percent of GDP, journal articles per capita, researchers per capita, competitiveness indices

- Stakeholder Impact: Owners, employees, and other stakeholders invest their resources into manufacturing with the purpose of receiving some benefit. The costs and return that they receive can drive industry productivity and growth. However, data is limited on this topic area.

○ Metrics: Number of employees, compensation, safety incidents, profits

- Areas for Advancement: It is important to identify areas of investment that have the potential to have a high return, which can facilitate productivity and growth in manufacturing.

○ Metrics: High cost supply chain components

Currently, this annual report discusses items related to inputs for production and outputs from production. It does not discuss negative externalities, the inputs that are used in the function of a product (e.g., gasoline for an automobile), or the function of the product; however, these items might be included in future reports.

Manufacturing metrics can be categorized by stakeholder, scale, and metric type (see Figure 1.2). Stakeholders include the individuals that have an interest in manufacturing. All the metrics in this report relate directly or indirectly to all or a selection of stakeholders. The benefits for some stakeholders are costs for other stakeholders. For instance, the price of a product is a cost to the consumer but represents compensation and profit for the producers. The scale indicates whether the metric is nominal (e.g., the total U.S. manufacturing revenue) or is adjusted to a notionally common scale (e.g., revenue per capita). The metric type distinguishes whether the metric measures manufacturing

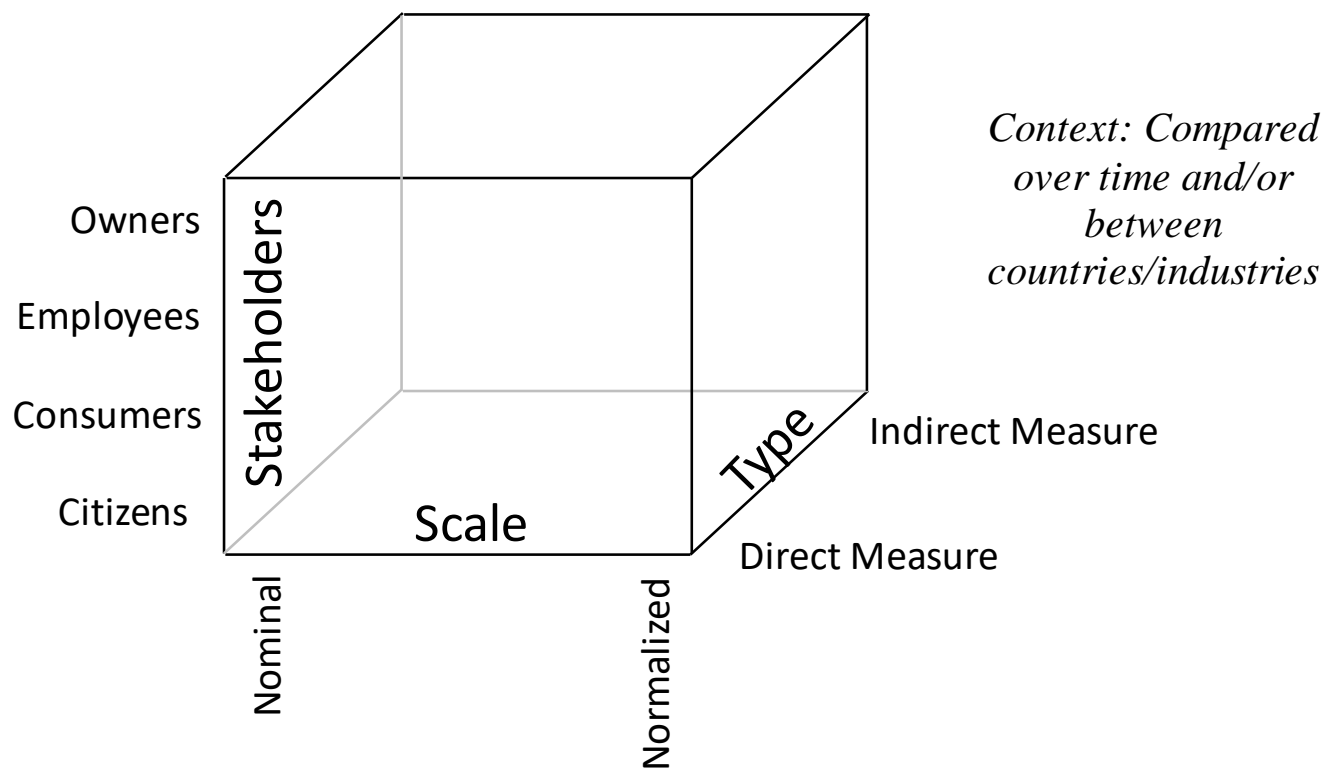

Figure 1.2: Data Categorization for Examining the Economics of Manufacturing 
activities directly (e.g., total employment) or measures those things that affect manufacturing (e.g., research and development). These metrics are then compared over time and/or between industries to provide context to U.S. manufacturing activities.

\subsection{Scope and Approach}

There are numerous aspects one could examine in manufacturing. This report discusses a subset of stakeholders and focuses on U.S. manufacturing. Among the many datasets available, it utilizes those that are prominent and are consistent with economic standards. These criteria are further discussed below.

Stakeholders: This report focuses on the employees and the owners/investors, as the data available facilitates examining these entities. Future work may move toward examining other stakeholders in manufacturing, such as the consumers and general public.

Geographic Scope: Many change agents are concerned with a certain group of people or organizations. Since NIST is concerned with "U.S. innovation and competitiveness," this report focuses on activities within national borders. In a world of globalization, this effort is challenging, as some of the parts and materials being used in U.S.-based manufacturing activities are imported. The imported values are a relatively small percentage of total activity, but they are important in regard to a firm's production. NIST, however, promotes U.S. innovation and industrial competitiveness; therefore, consideration of these imported goods and services are outside of the scope of this report.

Standard Data Categorization: Domestic data in the U.S. tends to be organized using NAICS codes, which are the standard used by federal statistical agencies classifying business establishments in the United States. NAICS was jointly developed by the U.S. Economic Classification Policy Committee, Statistics Canada, and Mexico's Instituto Nacional de Estadística y Geografía, and was adopted in 1997. NAICS has several major categories each with subcategories. Historic data and some organizations continue to use the predecessor of NAICS, which is the Standard Industrial Classification system (SIC). NAICS codes are categorized at varying levels of detail. The broadest level of detail is the two-digit NAICS code, which has 20 categories. More detailed data is reported as the number of digits increase; thus, three-digit NAICS provide more detail than the two-digit and the four-digit provides more detail than the three-digit. The maximum is six digits. Sometimes a two, three, four, or five-digit code is followed by zeros, which do not represent categories. They are null or place holders. For example, the code 336000 represents NAICS 336. International data tends to be in the International Standard Industrial Classification (ISIC) version 3.1, a revised United Nations system for classifying economic data. Manufacturing is broken into 23 major categories (ISIC 15 through 37 ), with additional subcategorization. This data categorization works similar to NAICS in that additional digits represent additional detail.

Data Sources: Thomas (2012) explores a number of data sources for examining U.S. manufacturing activity. ${ }^{9}$ This report selects from sources that are the most prominent and

${ }^{9}$ Thomas, Douglas S. (2012). The Current State and Recent Trends of the U.S. Manufacturing Industry. NIST Special Publication 1142. http://nvlpubs.nist.gov/nistpubs/SpecialPublications/NIST.SP.1142.pdf 
reveal the most information about the U.S. manufacturing industry. These data include the United Nations Statistics Division's National Accounts Main Aggregates Database and the U.S. Census Bureau's Annual Survey of Manufactures, among others. Because the data sources are scattered across several resources, there are differences in what yearly data is available for a particular category or topic. In each case, the most-up-todate and available information is provided for the relevant category.

Data Limitations: Like all collections of information, the data on manufacturing has limitations. In general, there are 3 aspects to economic data of this type: 1) breadth of the data, 2) depth of the data, and 3) the timeliness of the data. The breadth of the data refers to the span of items covered, such as the number of countries and years. The depth of the data refers to the number of detailed breakouts, such as value added, expenditures, and industries. In general, breadth and depth are such that when the number of items in each are multiplied together it equals the number of observations in the dataset for a particular time period. For instance, if you have value added data on 5 industries for 20 countries for a single year, then you would have 100 observations (i.e., 5 × $20=100$ ). The timeliness of the data refers to how recently the data was released. For instance, is the data 1 year old or 5 years old at release. In general, data can perform well in 2 of these 3 criteria, but it is less common to perform well on all 3 due to feasibility of data collection (see Figure 1.3). Moreover, in this report there is data that is very recent (timeliness) and spans numerous subsectors (depth), but it only represents the United States. On the other hand, there is data that spans multiple countries (breadth) and subsectors of manufacturing (depth); however, this data is from several years ago. Fortunately, industry level trends change slowly; thus, the data may not be from the most recent years, but it is still representative.

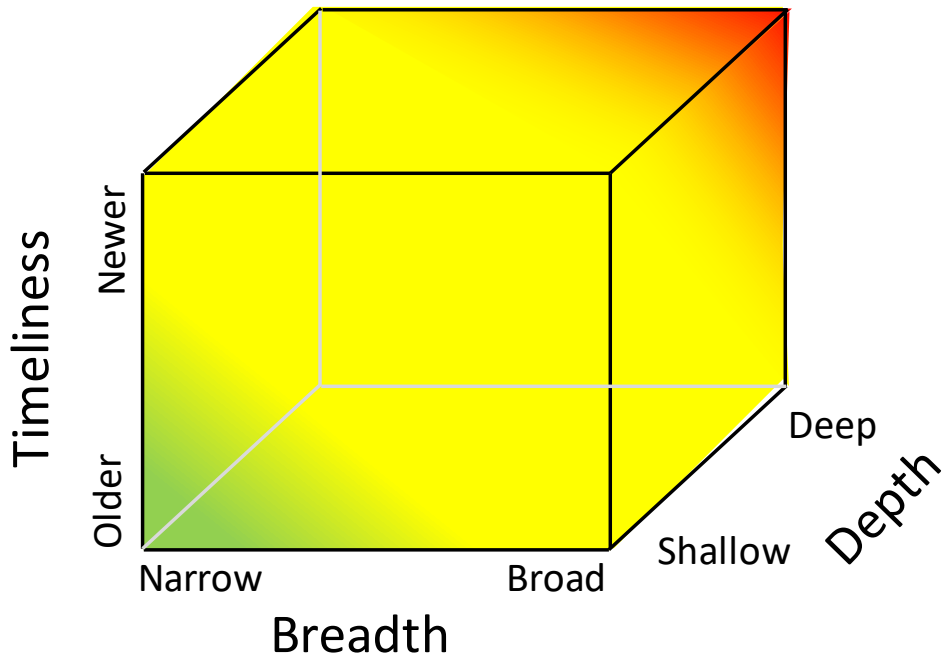

More Feasible

Figure 1.3: Illustration of the Feasibility of Data Collection and Availability 


\section{Value Added}

Value added is the primary metric used to measure economic activity. It is defined as the increase in the value of output at a given stage of production; that is, it is the value of output minus the cost of inputs from other establishments. ${ }^{10}$ The primary elements that remain after subtracting inputs is taxes, compensation to employees, and gross operating surplus; thus, the sum of these also equal value added. Gross operating surplus is used to calculate profit, which is gross operating surplus less the depreciation of capital such as buildings and machinery. The sum of all value added for a country is that nation's Gross Domestic Product (GDP).

\subsection{International Comparison}

There are a number of sources of international estimates of value added for manufacturing. The United Nations Statistics Division National Accounts Main Aggregates Database has a wide-ranging dataset that covers a large number of countries over a significant period of time. In 2019, there was $\$ 13.9$ trillion of value added (i.e., GDP) in global manufacturing in constant 2015 dollars, which is $17.2 \%$ of the value added by all industries ( $\$ 80.6$ trillion), according to the United Nations Statistics Division. Since 1970, manufacturing ranged between $13.7 \%$ and $17.3 \%$ of global GDP. The top 10 manufacturing countries accounted for $\$ 10.0$ trillion or $72.0 \%$ of global manufacturing value added: China (29.4\%), United States (16.6\%), Japan (7.1\%), Germany (5.1\%), South Korea (3.1\%), India (2.0\%), Italy (2.0\%), United Kingdom $(2.0 \%)$, France $(1.9 \%)$, and Mexico $(1.5 \%) .{ }^{11}$

As seen in Figure 2.1, U.S. compound real (i.e., controlling for inflation) annual growth between 1994 and 2019 was $2.4 \%$, which places the U.S. below the $50^{\text {th }}$ percentile. This growth exceeded that of Germany, France, Canada, Japan, and Australia; however, it is slower than that for the world $(3.9 \%)$ and that of many emerging economies. It is important to note that emerging economies can employ idle or underutilized resources and adopt technologies that are already proven in other nations to achieve high growth rates. Developed countries are already utilizing resources and are employing advanced technologies; thus, comparing U.S. growth to the high growth rates in China or India has limited meaning. As seen in Figure 2.2, the compound annual growth for the U.S. between 2014 and 2019 was $1.9 \%$. This puts the U.S. just above the $25^{\text {th }}$ percentile above Canada and Germany among others but below the world growth of $3.3 \%$.

As seen in Figure 2.3, among the largest manufacturing nations, U.S. manufacturing value added, as measured in constant 2015 dollars, is the second largest. In current

\footnotetext{
${ }^{10}$ Dornbusch, Rudiger, Stanley Fischer, and Richard Startz. (2000). Macroeconomics. 8th ed. London, UK: McGraw-Hill.

${ }^{11}$ United Nations Statistics Division. (2020). "National Accounts Main Aggregates Database." http://unstats.un.org/unsd/snaama/Introduction.asp
} 


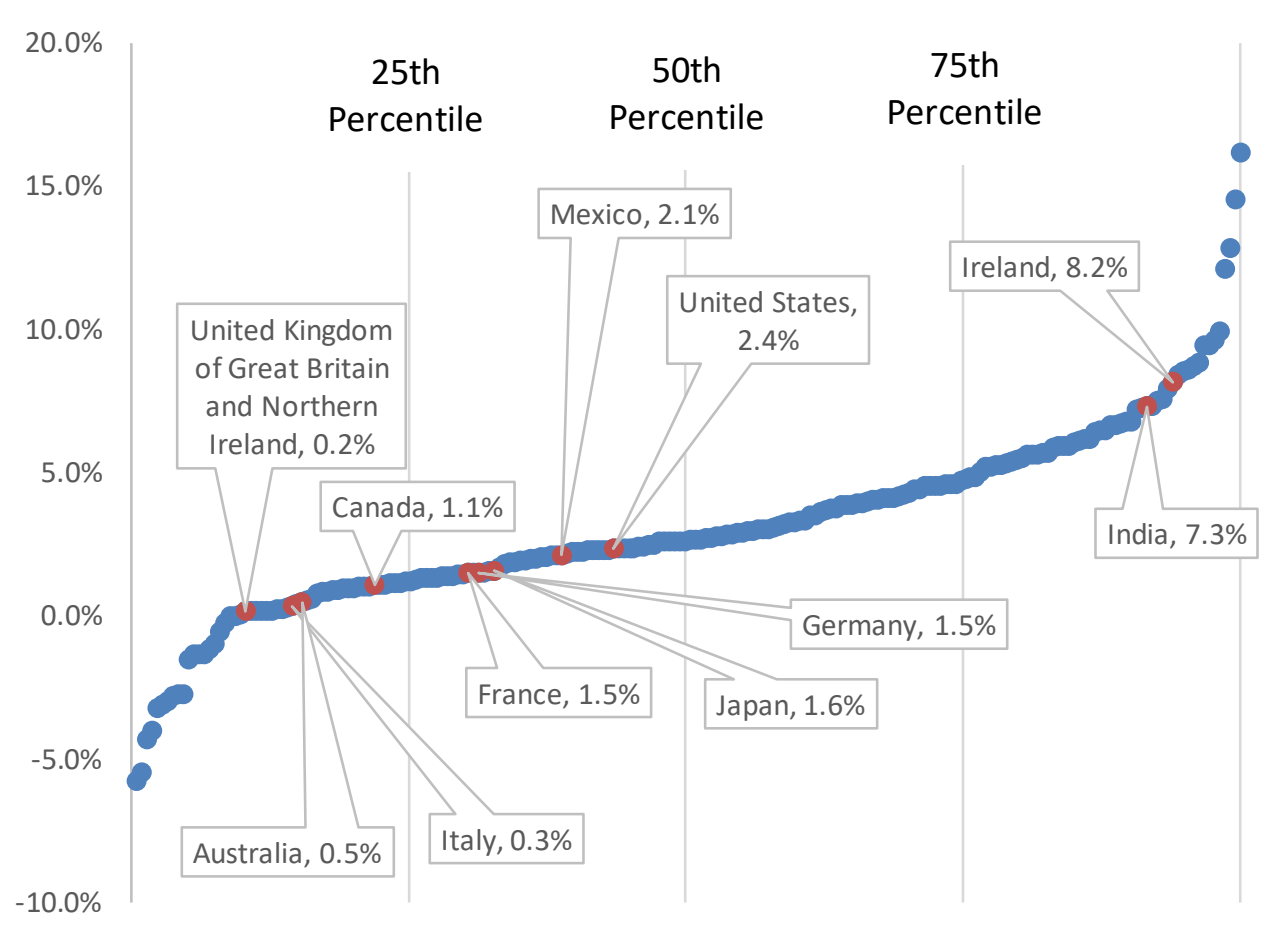

Figure 2.1: National 25-Year Compound Annual Growth, by Country (1994 to 2019): Higher is Better

Data Source: United Nations Statistics Division. (2021). "National Accounts Main Aggregates Database." http://unstats.un.org/unsd/snaama/Introduction.asp

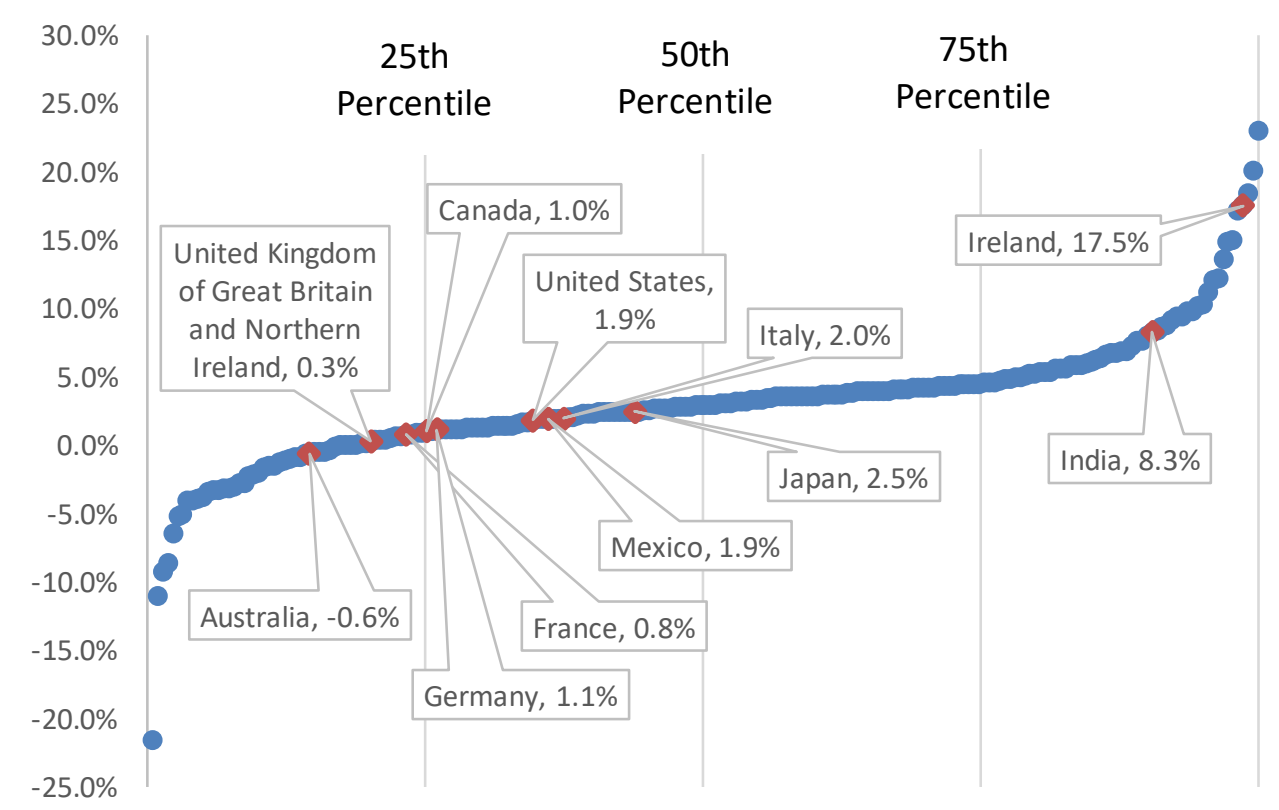

Figure 2.2: National 5-Year Compound Annual Growth, by Country (2014 to 2019): Higher is Better Data Source: United Nations Statistics Division. (2021). "National Accounts Main Aggregates Database." http://unstats.un.org/unsd/snaama/Introduction.asp 


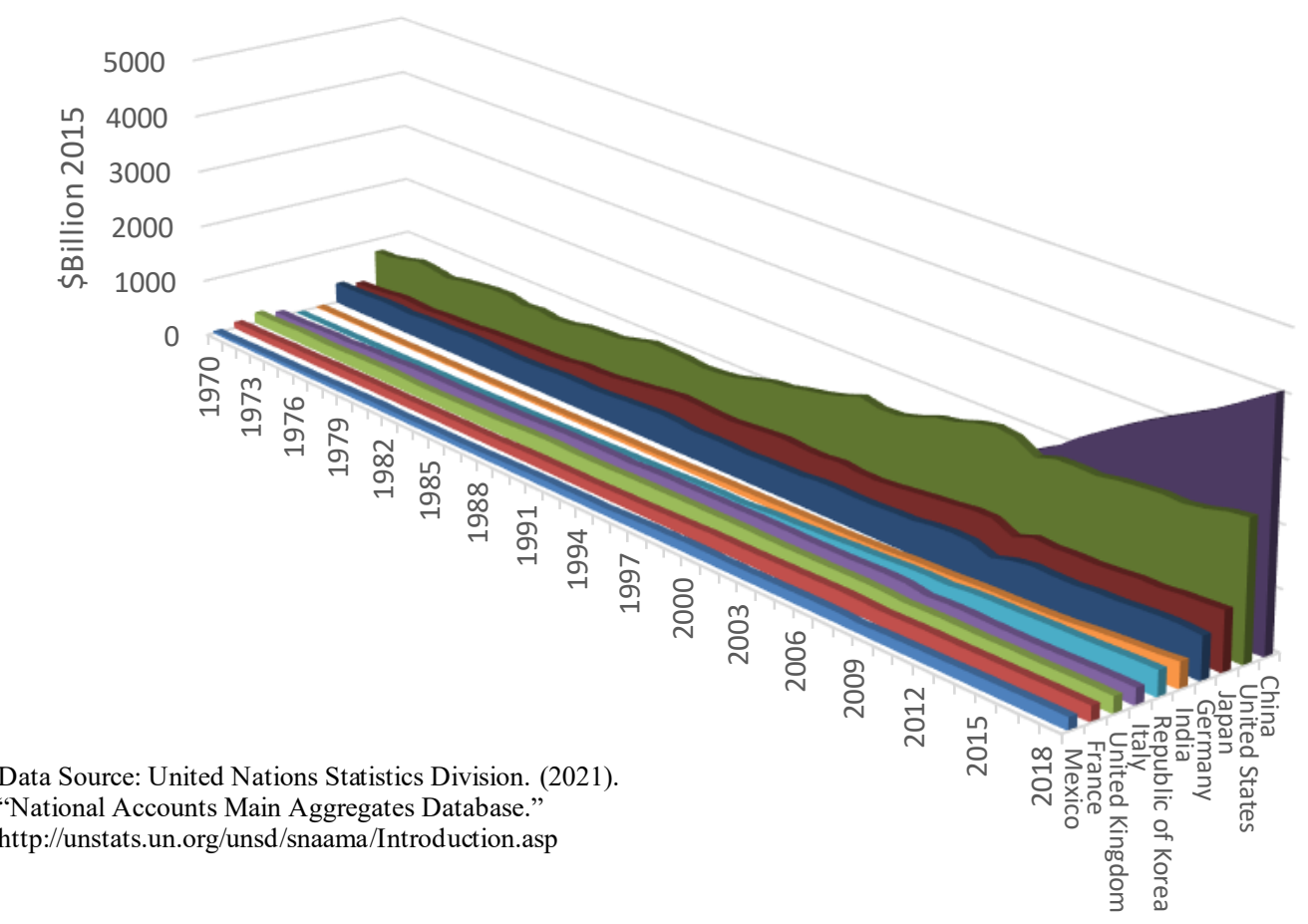

Figure 2.3: Manufacturing Value Added, Top 10 Manufacturing Countries (1970 to 2019)

dollars, the U.S. produced $\$ 2.3$ trillion in manufacturing valued added while China produced $\$ 4.0$ trillion. Among the ten largest manufacturing countries, the U.S. has the $4^{\text {th }}$ largest manufacturing value added per capita, as seen in Figure 2.4. Out of all countries the U.S. ranks $14^{\text {th }}$, as seen in Figure 2.5. Since 1970, the U.S. ranking has ranged between $11^{\text {th }}$ and $17^{\text {th }}$. It is important to note that there are varying means for adjusting data that can change the rankings. The UNSD data uses market exchange rates while others might use purchasing power parity (PPP) exchange rates. PPP is the rate that a currency in one country would have to be converted to purchase the same goods and services in another country. The drawback of PPP is that it is difficult to measure and methodological questions have been raised about some surveys that collect data for these calculations. ${ }^{12}$ Market based rates tend to be relevant for internationally traded goods; ${ }^{13}$ therefore, this report utilizes these rates.

In terms of subsectors of manufacturing, the U.S. ranks $1^{\text {st }}$ in 7 industries out of 16 total, as seen in Figure 2.6 while China was the largest for the other industries. Since this data covers multiple industries for multiple years (i.e., it has breadth and depth), it is a few years old (i.e., 2015). Nonetheless, it likely provides an accurate representation, as national activity generally moves slowly.

${ }^{12}$ Callen, Tim. March. (2007). PPP Versus the Market: Which Weight Matters? Finance and Development. Vol 44 number 1. http://www.imf.org/external/pubs/ft/fandd/2007/03/basics.htm

${ }^{13}$ Ibid. 


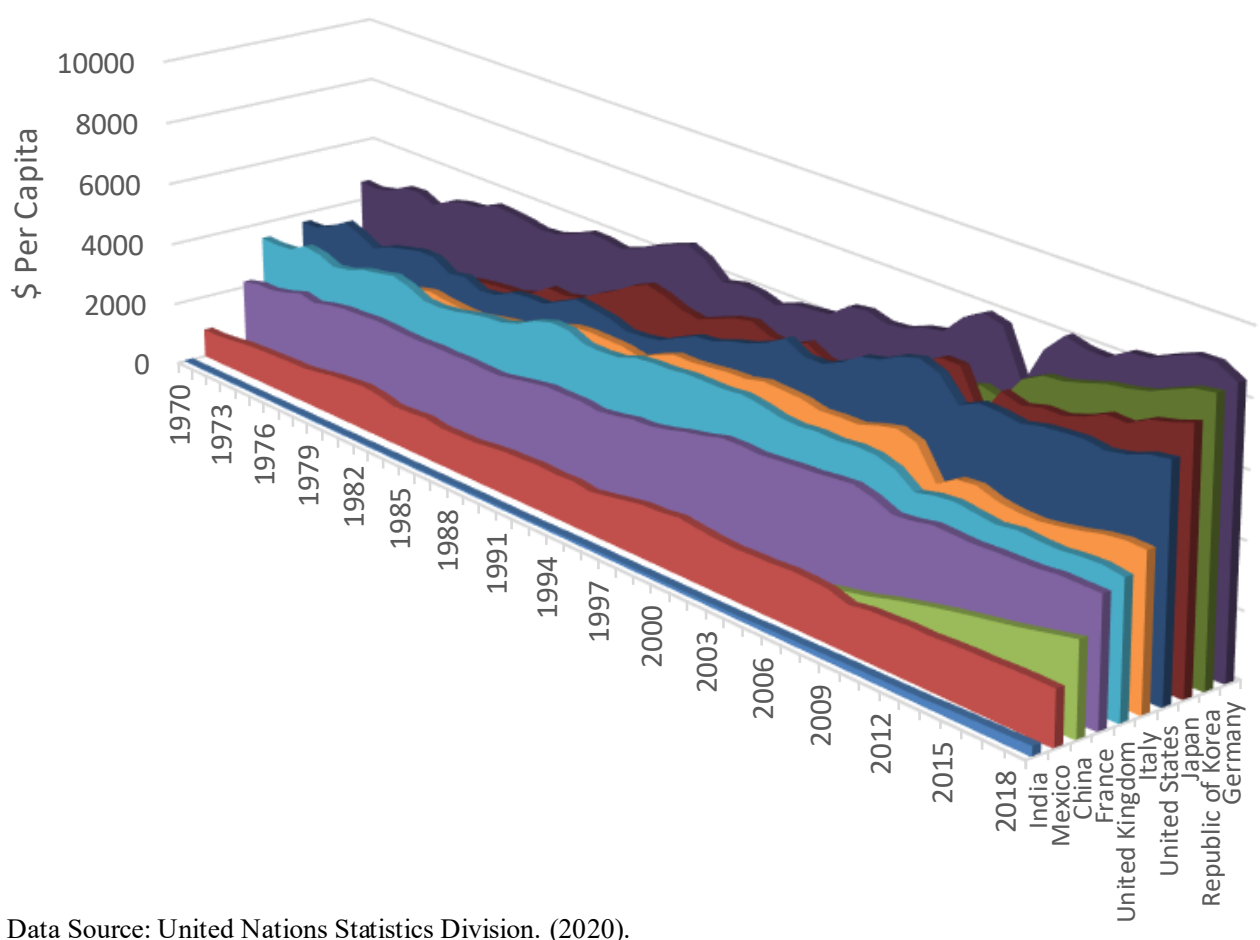

Data Source: United Nations Statistics Division. (2020)

"National Accounts Main Aggregates Database."

http://unstats.un.org/unsd/snaama/Introduction.asp

Figure 2.4: Manufacturing Value Added Per Capita, Top 10 Largest Manufacturing Countries (1970 to 2019): Higher is Better

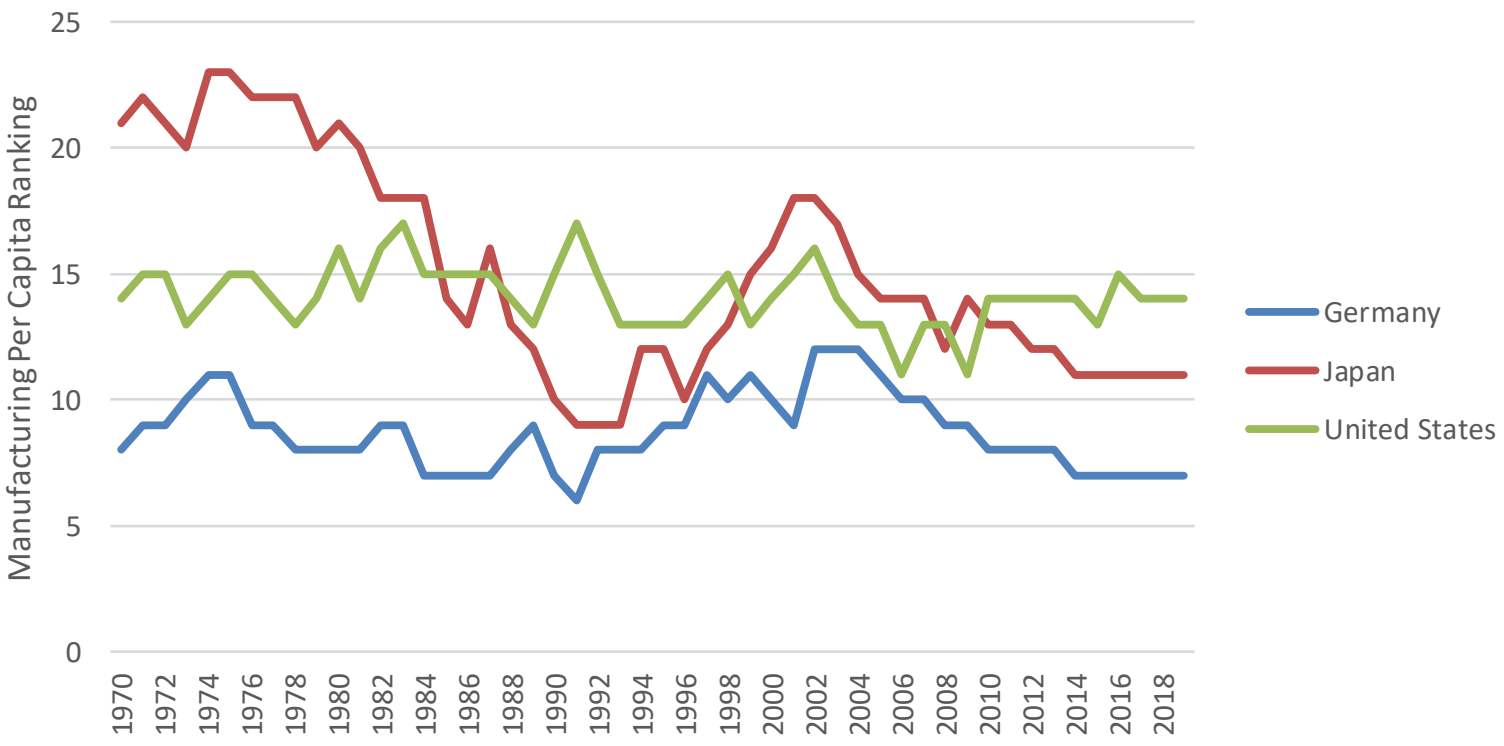

Figure 2.5: Manufacturing Per Capita Ranking, 1970-2019: Lower is Better

Data Source: United Nations Statistics Division. (2020). "National Accounts Main Aggregates Database." http://unstats.un.org/unsd/snaama/Introduction.asp 


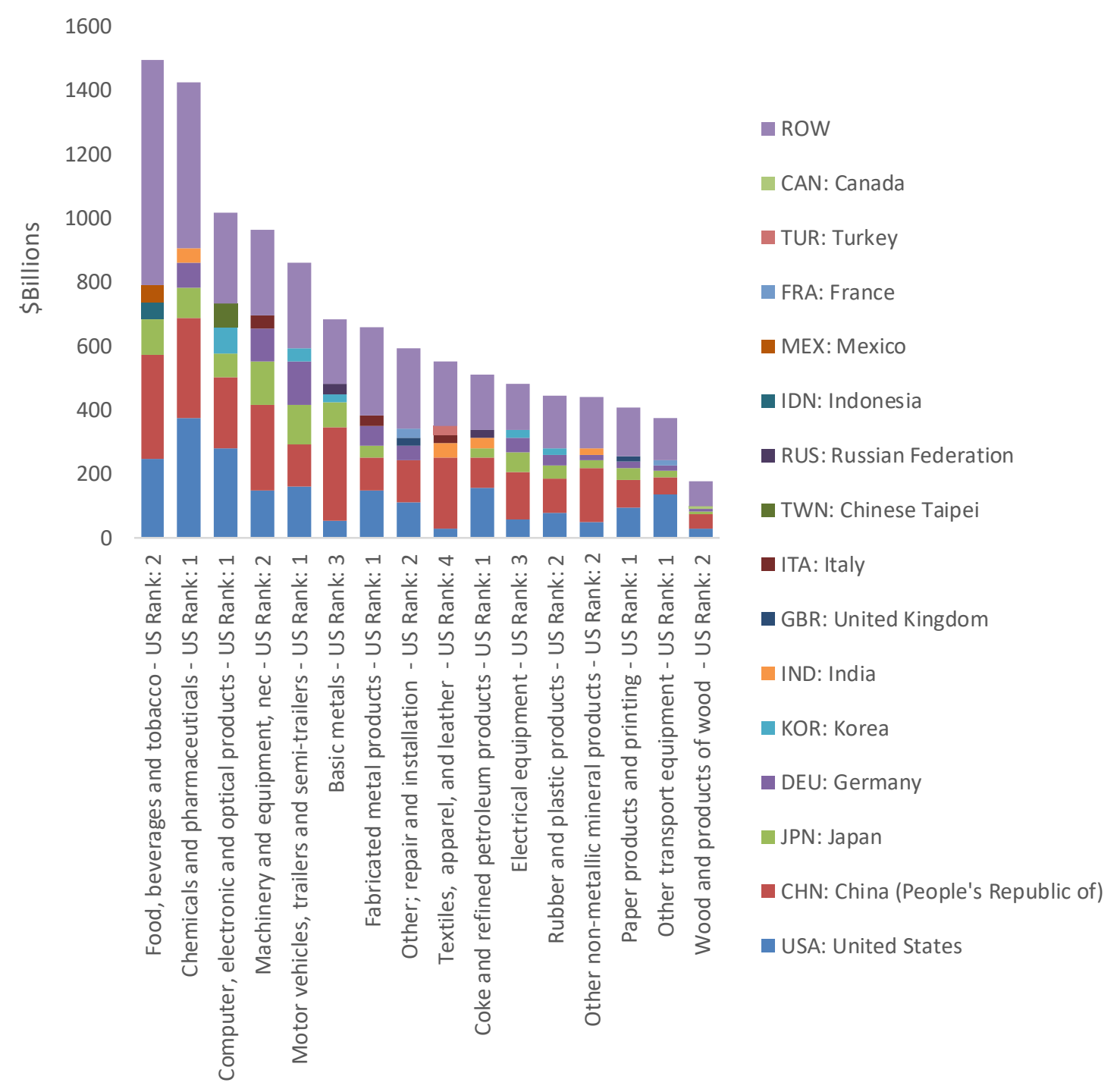

Figure 2.6: Global Manufacturing Value Added by Industry, Top Five Producers and Rest of World (ROW) (2015) - 64 Countries

Source: OECD. (2020) STAN Input-Output Tables. https://stats.oecd.org/

\subsection{Domestic Details}

Bureau of Economic Analysis - Chained Dollars: There are two primary methods for adjusting value added for inflation. The first is using chained dollars, which uses a changing selection of goods to adjust for inflation. The second uses an unchanging selection of goods to adjust for inflation. ${ }^{14}$ Both are discussed in this report, as there has been some dispute about the accuracy of chained dollars for some goods.

${ }^{14}$ Dornbusch, Rudiger, Stanley Fischer, and Richard Startz. (2000). Macroeconomics. 8th ed. London, UK: McGraw-Hill. 32. 
As illustrated in Figure 2.7, from the peak in the $4^{\text {th }}$ quarter of 2007 to the $1^{\text {st }}$ quarter of 2009 manufacturing declined $15.2 \%$ and only recently returned to its pre-recession peak level in 2017. Manufacturing value added declined more than total U.S. GDP, creating a persistent gap. The result is that first quarter GDP in 2021 is $29.2 \%$ above its 2005 level while manufacturing is at $21.5 \%$ above its 2005 level. However, from the $4^{\text {th }}$ quarter of 2019 to the $2^{\text {nd }}$ quarter of 2020 , total GDP declined $10.1 \%$ and manufacturing value added declined $12.2 \%{ }^{15}$

Manufacturing value added in the U.S. in 2019 was \$2153.6 billion in chained 2012 dollars or $11.7 \%$ of GDP. ${ }^{16}$ Using chained dollars from the BEA shows that manufacturing decreased by $2.8 \%$. Figure 2.8 and Figure 2.9 provide more detailed data on durable and nondurable goods within the manufacturing industry. As seen in Figure 2.8 , value added for seven of eleven durable goods industries is higher in 2020 than it was in 2005, including computer and electronic products and motor vehicles. The growth in durable goods is largely driven by computer and electronic products, which should be viewed with some caution, as there has been some dispute regarding the price adjustments for this sector, which affects the measured growth. Recall that the U.S. is also the largest producer of computer and electronic products. As seen in Figure 2.9, in 2020 only two non-durable sector is above its 2005 value. The largest manufacturing subsector in the U.S. is computer and electronic products followed by chemical manufacturing, and food, beverage, and tobacco products, as seen in Figure 2.10. Note that this is based on chained dollars. Adjustments using other methods or the nominal value can have different results.

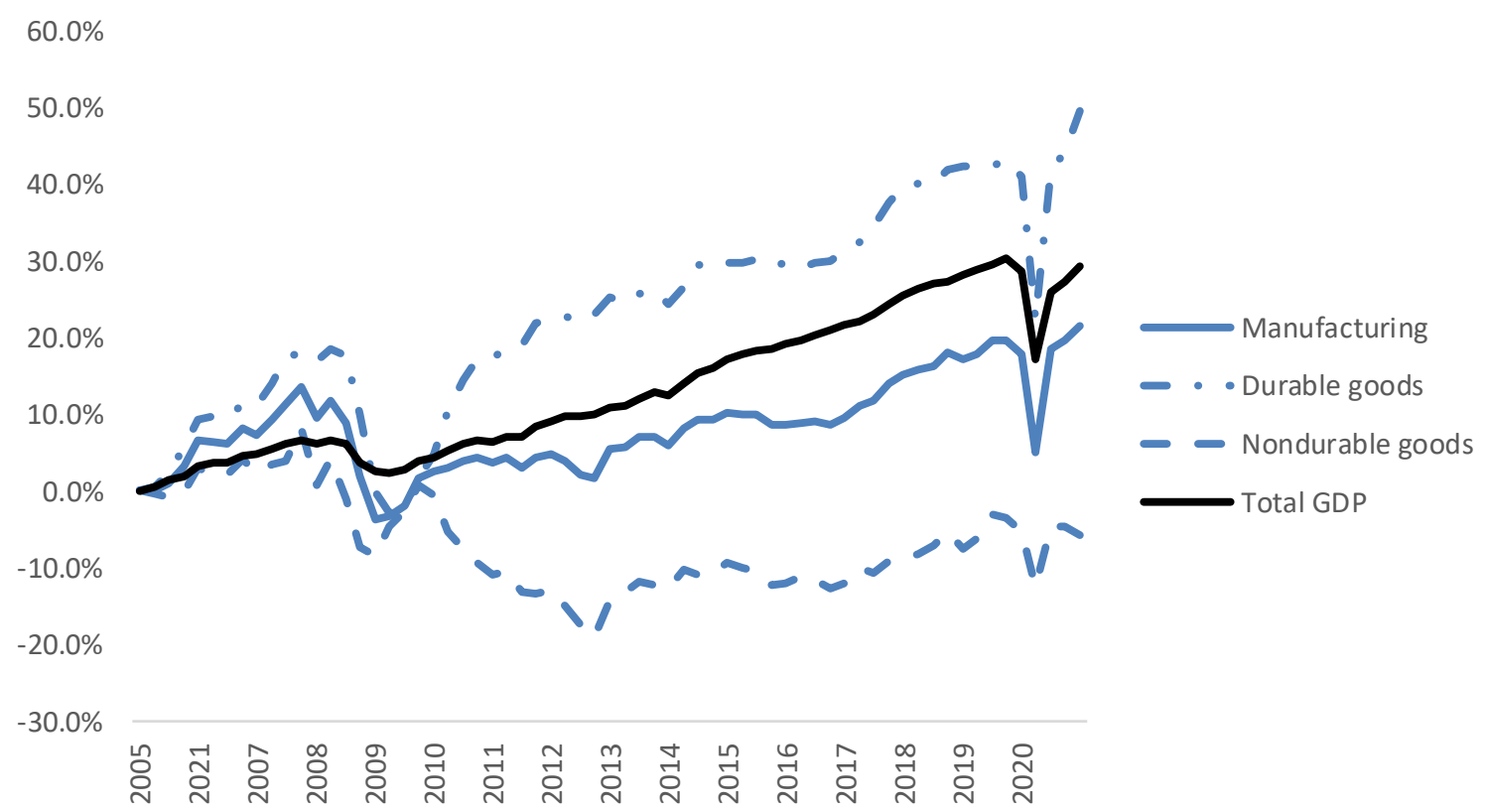

Figure 2.7: Cumulative Percent Change in Value Added (2012 Chained Dollars)

Bureau of Economic Analysis. 2021. "Industry Economic Accounts Data." http://www.bea.gov/iTable/index_industry_gdpIndy.cfm

${ }^{15}$ Bureau of Economic Analysis. (2021) "Industry Economic Accounts Data." http://www.bea.gov/iTable/index_industry_gdpIndy.cfm

${ }^{16}$ Bureau of Economic Analysis. (2021) "Industry Economic Accounts Data." http://www.bea.gov/iTable/index_industry_gdpIndy.cfm 


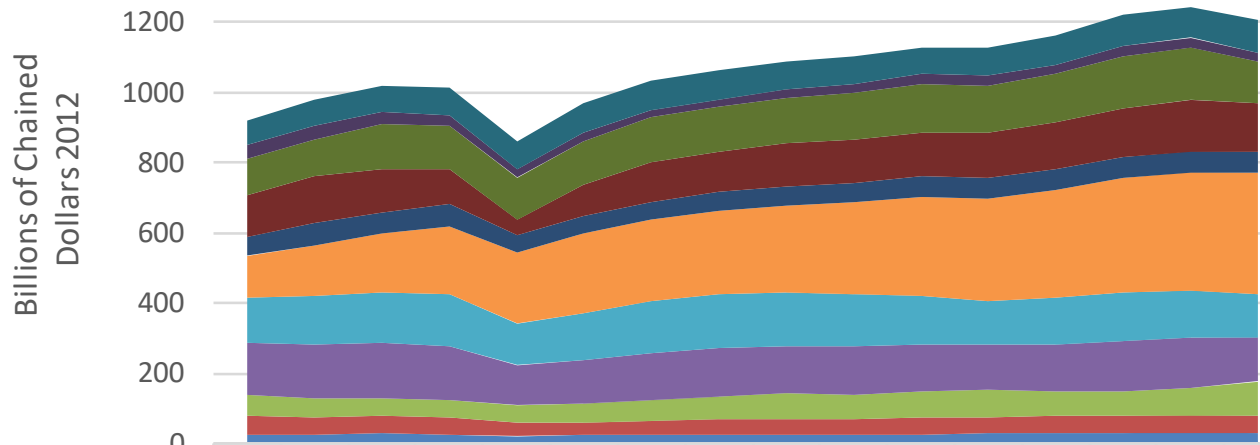

\begin{tabular}{|l|l|l|l|l|l|l|l|l|l|l|l|l|l|l|l|}
\hline 2005 & 2006 & 2007 & 2008 & 2009 & 2010 & 2011 & 2012 & 2013 & 2014 & 2015 & 2016 & 2017 & 2018 & 2019 & 2020 \\
\hline
\end{tabular}

- Miscellaneous manufacturing

- Furniture and related products

- Other transportation equipment

- Motor vehicles, bodies and trailers, and parts

- Electrical equipment, appliances, and components

- Computer and electronic products

- Machinery

- Fabricated metal products

- Primary metals

- Nonmetallic mineral products

- Wood products

Figure 2.8: Value Added for Durable Goods by Type (billions of chained dollars), 2005-2020

Data Source: Bureau of Economic Analysis. (2021) "Industry Economic Accounts Data."

http://www.bea.gov/iTable/index_industry_gdpIndy.cfm

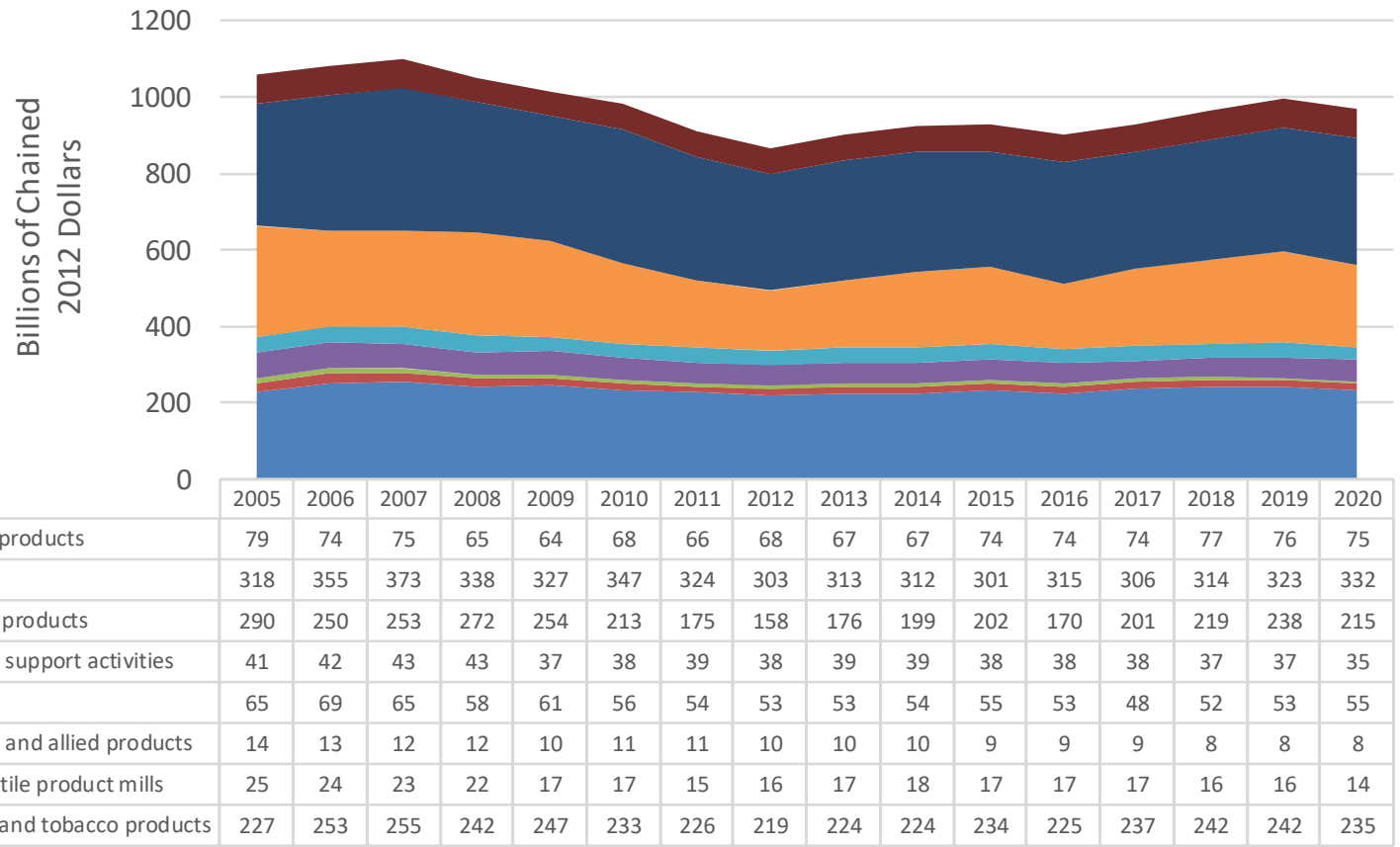

Figure 2.9: Value Added for Nondurable Goods by Type (billions of chained dollars), 2005-2020:

Higher is Better

Data Source: Bureau of Economic Analysis. (2021) "Industry Economic Accounts Data."

http://www.bea.gov/iTable/index_industry_gdpIndy.cfm 


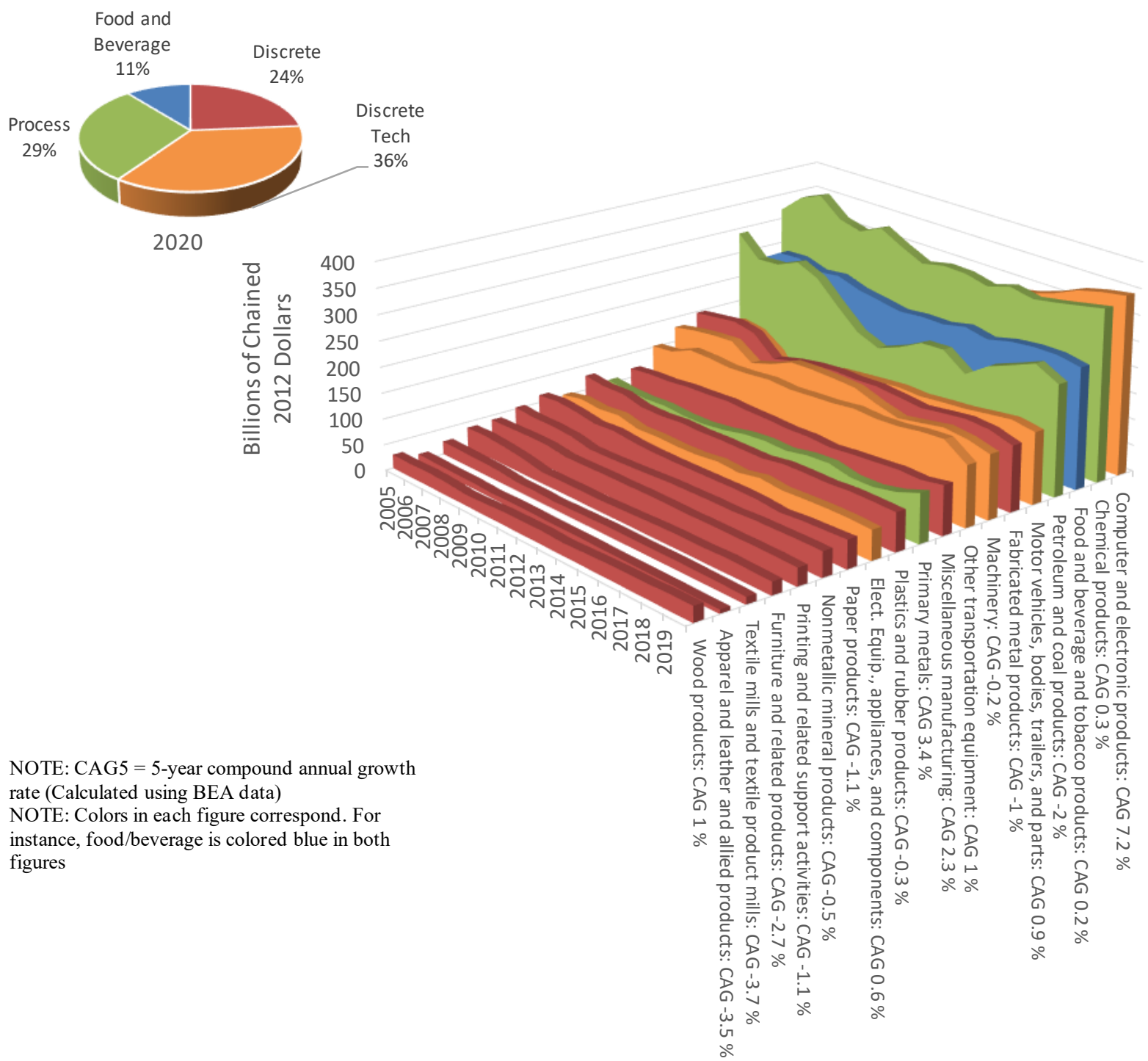

Figure 2.10: Manufacturing Value Added by Subsector (billions of chained dollars)

Data Source: Bureau of Economic Analysis. (2021) "Industry Economic Accounts Data."

http://www.bea.gov/iTable/index_industry_gdpIndy.cfm

Bureau of Economic Analysis - Constant Dollars: In 2020, U.S. manufacturing accounted for \$ 2269.2 billion in value added or $10.8 \%$ of GDP, as measured in constant 2020 dollars.

Some concerns have been raised regarding the use of chained dollars to adjust for inflation; ${ }^{17}$ therefore, it is prudent to examine manufacturing value added using the producer price index. Figure 2.11 and Figure 2.12 presents value added for durable and nondurable goods adjusted using the producer price index from the Bureau of Labor Statistics. The general trends are similar to those calculated using chained dollars; however, there are some differences. For instance, between 2005 and 2020 chemical products grew $8.0 \%$, measured in constant dollars, while it grew only $4.3 \%$ when measured using chained dollars. As seen in

\footnotetext{
${ }^{17}$ Bureau of Economic Analysis. (1997). BEA's Chain Indexes, Time Series, and Measures of Long-Term Economic Growth. https://www.bea.gov/scb/account_articles/national/0597od/maintext.htm
} 
700.0

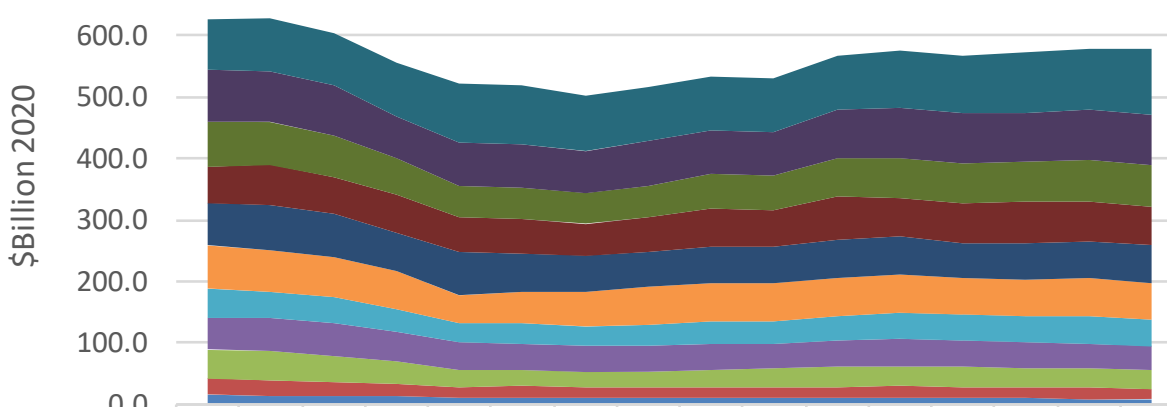

0.0

\begin{tabular}{|l|l|l|l|l|l|l|l|l|l|l|l|l|l|l|l|}
\hline 2005 & 2006 & 2007 & 2008 & 2009 & 2010 & 2011 & 2012 & 2013 & 2014 & 2015 & 2016 & 2017 & 2018 & 2019 & 2020 \\
\hline
\end{tabular}

- Miscellaneous manufacturing \begin{tabular}{|l|l|l|l|l|l|l|l|l|l|l|l|l|l|l|l|}
82.9 & 86.6 & 86.8 & 88.3 & 93.9 & 94.5 & 89.2 & 88.8 & 87.1 & 88.4 & 87.1 & 92.7 & 95.1 & 98.2 & 98.3 & 107.5 \\
\hline
\end{tabular}

- Furniture and related products \begin{tabular}{|l|l|l|l|l|l|l|l|l|l|l|l|l|l|l|l|}
\hline 85.7 & 82.3 & 80.9 & 66.8 & 72.0 & 71.6 & 68.6 & 71.9 & 72.0 & 69.2 & 81.6 & 84.1 & 80.1 & 81.2 & 82.9 & 82.7 \\
\hline
\end{tabular}

- Other transportation equipment \begin{tabular}{|l|l|l|l|l|l|l|l|l|l|l|l|l|l|l|l|}
71.4 & 68.7 & 66.9 & 58.2 & 49.7 & 49.5 & 49.3 & 52.6 & 56.4 & 57.6 & 61.8 & 63.2 & 65.6 & 65.2 & 66.3 & 67.0 \\
\hline
\end{tabular}

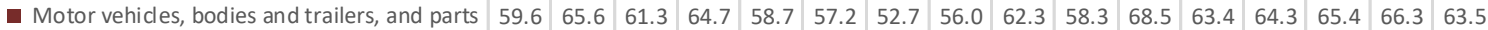

- Electrical equipment, appliances, and components

- Computer and electronic products \begin{tabular}{|l|l|l|l|l|l|l|l|l|l|l|l|l|l|l|l|}
69.3 & 74.0 & 68.9 & 59.9 & 68.9 & 63.4 & 58.5 & 57.5 & 59.8 & 59.4 & 62.6 & 61.8 & 56.9 & 59.7 & 60.3 & 60.6 \\
\hline
\end{tabular}

- Machinery

- Fabricated metal products \begin{tabular}{|l|l|l|l|l|l|l|l|l|l|l|l|l|l|l|l|}
70.3 & 68.2 & 66.1 & 63.3 & 46.5 & 50.6 & 56.1 & 61.6 & 61.2 & 62.2 & 63.7 & 63.3 & 60.0 & 59.7 & 60.6 & 59.5 \\
\hline
\end{tabular} \begin{tabular}{|l|l|l|l|l|l|l|l|l|l|l|l|l|l|l|l|}
47.5 & 43.4 & 40.4 & 35.4 & 30.5 & 32.1 & 32.4 & 34.0 & 37.5 & 36.6 & 38.8 & 41.8 & 42.6 & 43.0 & 45.0 & 43.8 \\
\hline
\end{tabular}

Primary metals

- Nonmetallic mineral products

- Wood products

Figure 2.11: Value Added for Durable Goods by Type (constant dollars), 2005-2020

Adjusted using the Producer Price Index from the Bureau of Labor Statistics Data Source: Bureau of Economic Analysis. (2021) "Industry Economic Accounts Data."

http://www.bea.gov/iTable/index_industry_gdpIndy.cfm

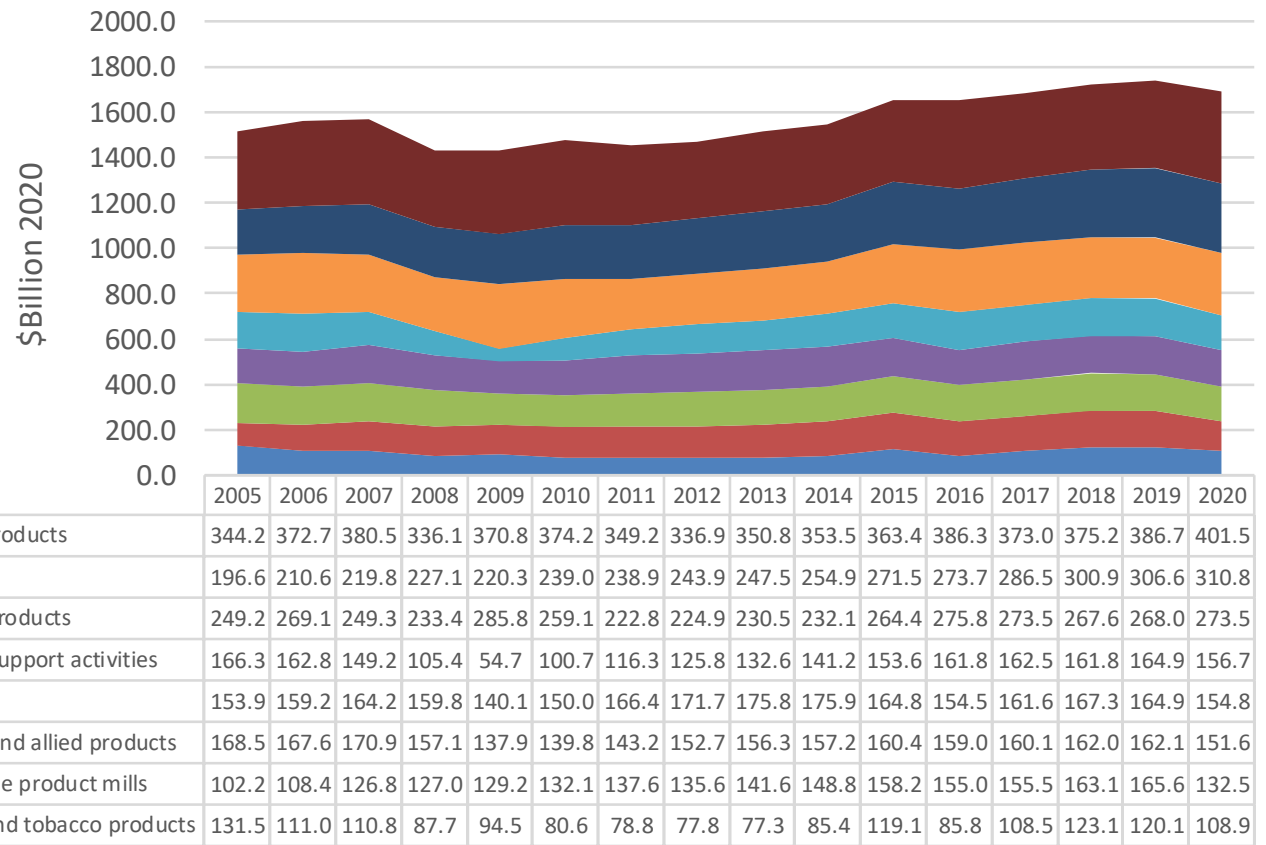

Figure 2.12: Value Added for Nondurable Goods by Type (constant dollars, billions), 2005-2020

Adjusted using the Producer Price Index from the Bureau of Labor Statistics

Data Source: Bureau of Economic Analysis. (2021) "Industry Economic Accounts Data."

http://www.bea.gov/iTable/index_industry_gdpIndy.cfm 


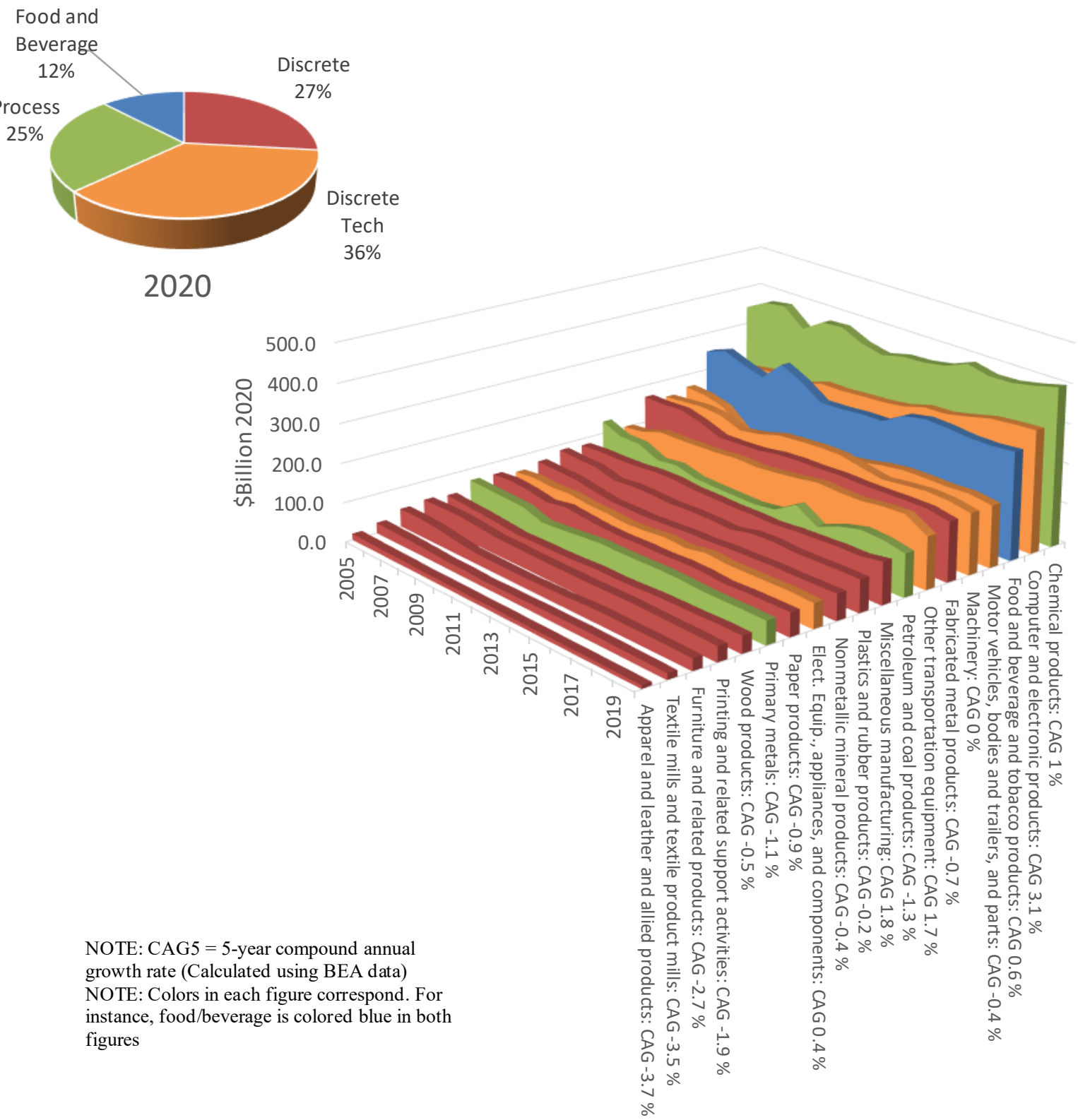

Figure 2.13: Manufacturing Value Added by Subsector, BEA (constant dollars, billions), 2005-2020 Adjusted using the Producer Price Index from the Bureau of Labor Statistics Data Source: Bureau of Economic Analysis. (2021) "Industry Economic Accounts Data." http://www.bea.gov/iTable/index_industry_gdpIndy.cfm

Figure 2.13, the five-year compound annual growth in computer and electronic manufacturing is $3.1 \%$ while it is $7.2 \%$ using chained dollars.

In addition to examining manufacturing value added, it is useful to examine the capital stock in manufacturing, as it reflects the value of machinery, buildings, and intellectual property in the industry (see Figure 2.14, Figure 2.15, Figure 2.16, and Figure 2.17). Discrete technology manufacturing (i.e., computer manufacturing, transportation equipment manufacturing, machinery manufacturing, and electronics manufacturing) account for $31 \%$ 
of all manufacturing equipment and $33 \%$ of structures. The 5-year compound annual growth in computer and electronic manufacturing equipment has declined and there has been limited growth in structures. Recall that in 2015, the U.S. was the largest producer of these goods and it is the second largest subsector of U.S. manufacturing.

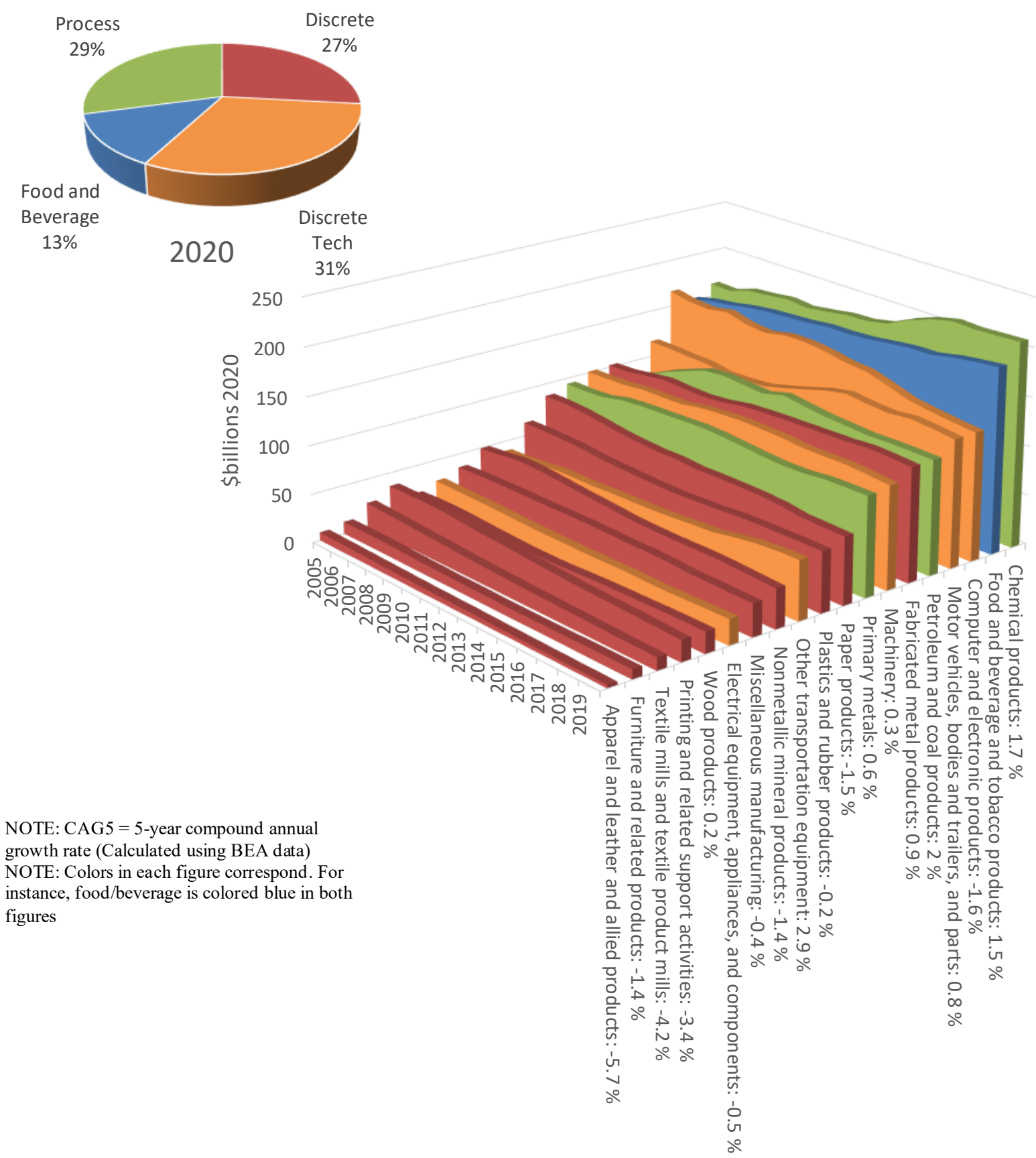

Figure 2.14: Current-Cost Net Stock: Private Equipment, Manufacturing (2005-2020)

Adjusted using the Consumer Price Index from the Bureau of Labor Statistics

Data Source: Bureau of Economic Analysis. (2021) "Fixed Assets Accounts Tables."

https://apps.bea.gov/iTable/iTable.cfm?ReqID $=10 \&$ step $=2$ 


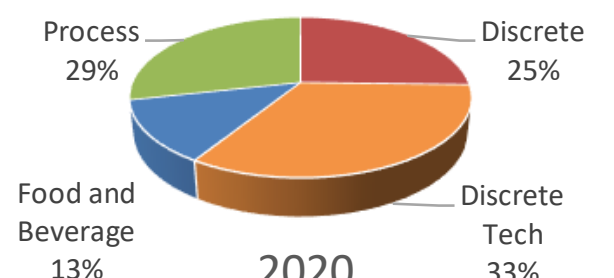

$13 \%$

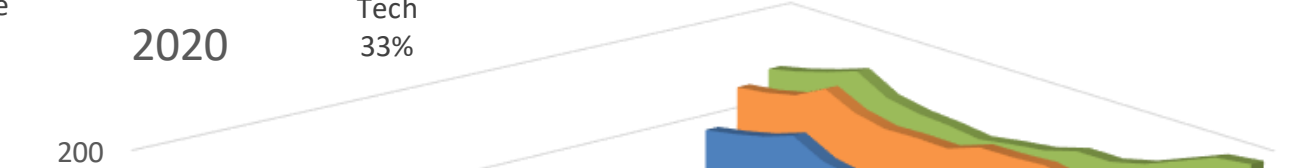

NOTE: CAG5 $=5$-year compound annua growth rate (Calculated using BEA data) NOTE: Colors in each figure correspond. For instance, food/beverage is colored blue in both figures

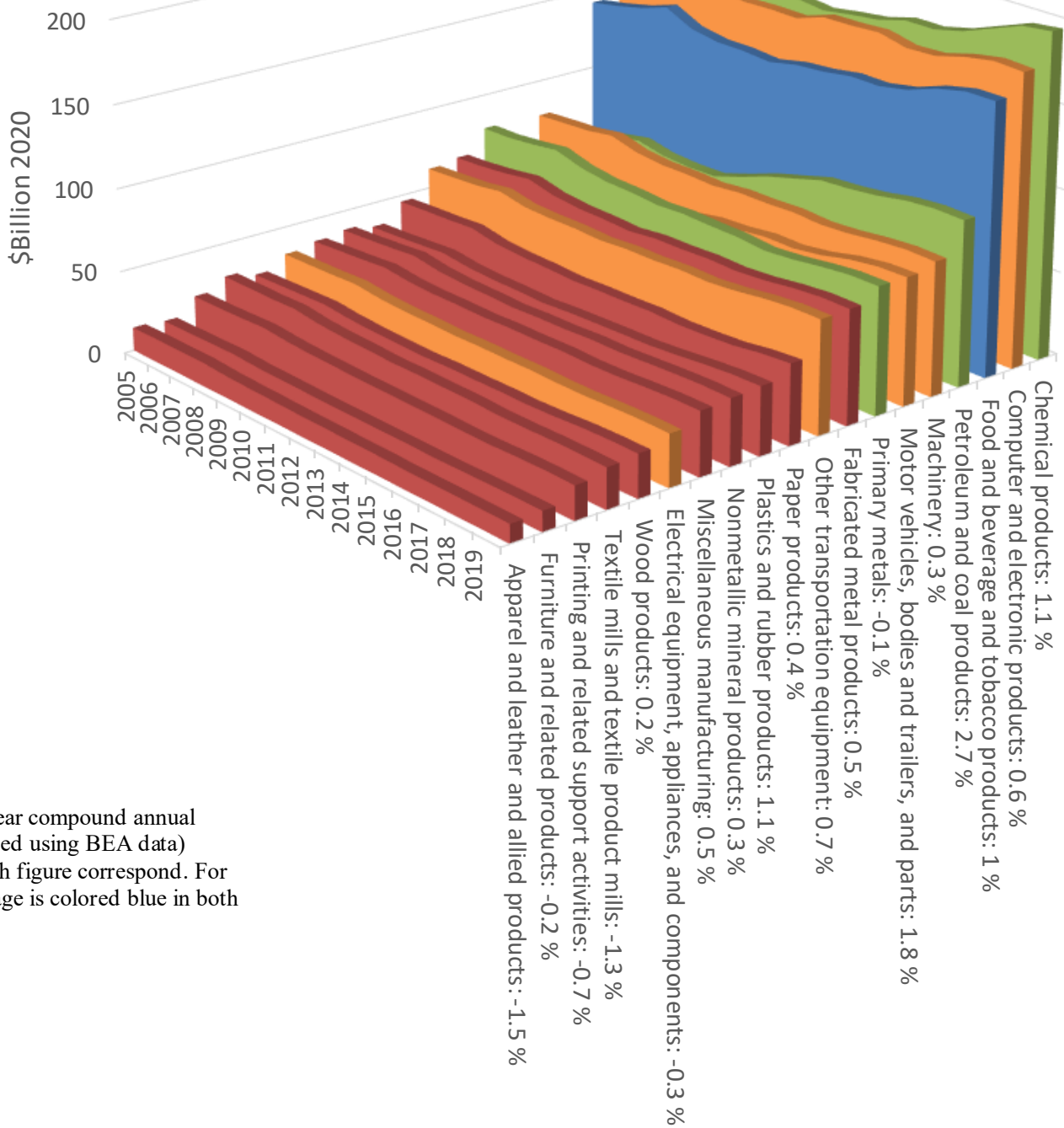

Figure 2.15: Current-Cost Net Stock: Private Structures, Manufacturing (2005-2020)

Adjusted using the Consumer Price Index from the Bureau of Labor Statistics

Data Source: Bureau of Economic Analysis. (2021) "Fixed Assets Accounts Tables." https://apps.bea.gov/iTable/iTable.cfm?ReqID $=10 \&$ step $=2$ 

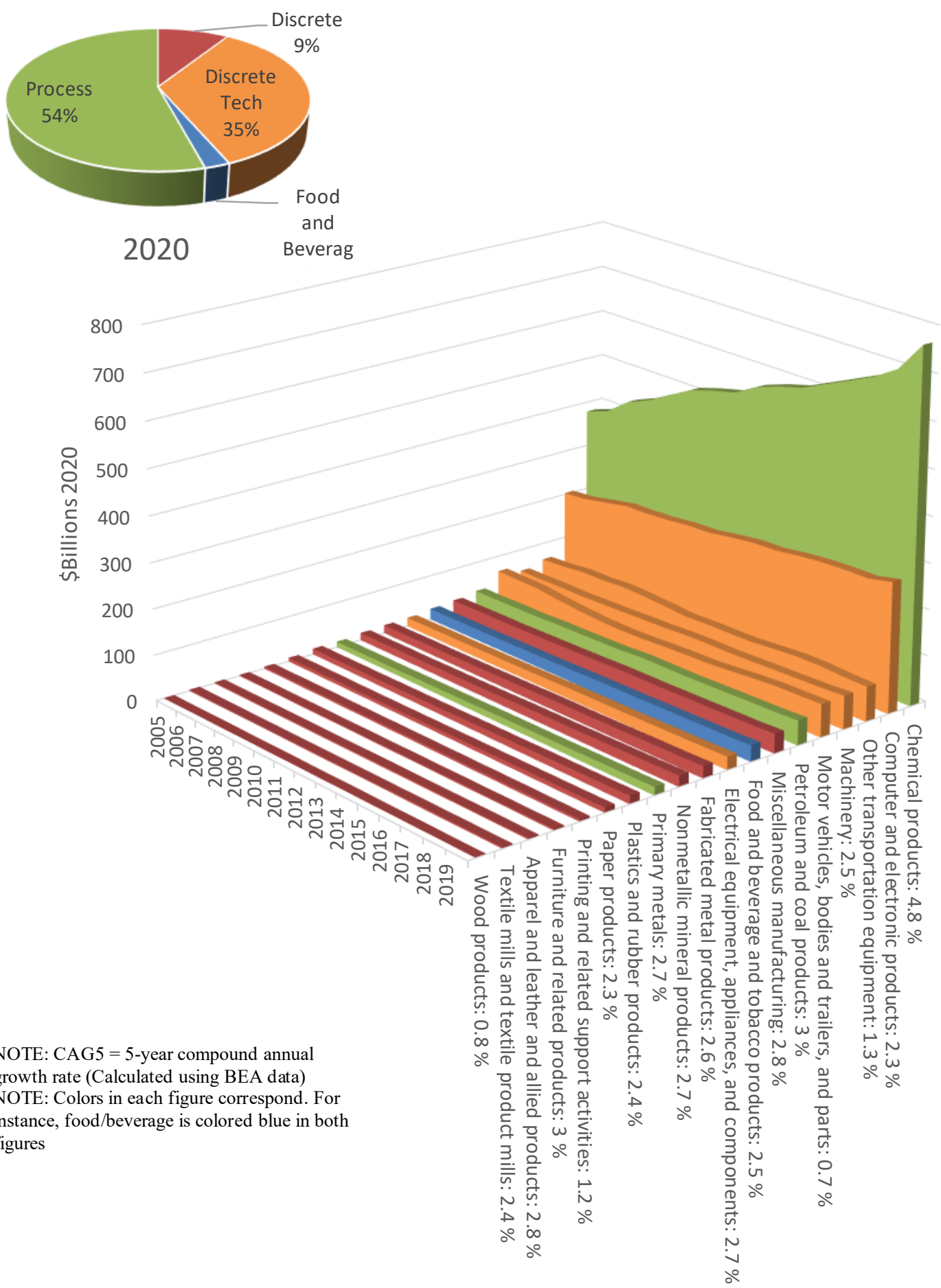

Figure 2.16: Current-Cost Net Stock: Intellectual Property Products, Manufacturing (2005-2020)

Adjusted using the Consumer Price Index from the Bureau of Labor Statistics

Data Source: Bureau of Economic Analysis. (2021) "Fixed Assets Accounts Tables."

https://apps.bea.gov/iTable/iTable.cfm?ReqID=10\&step=2 


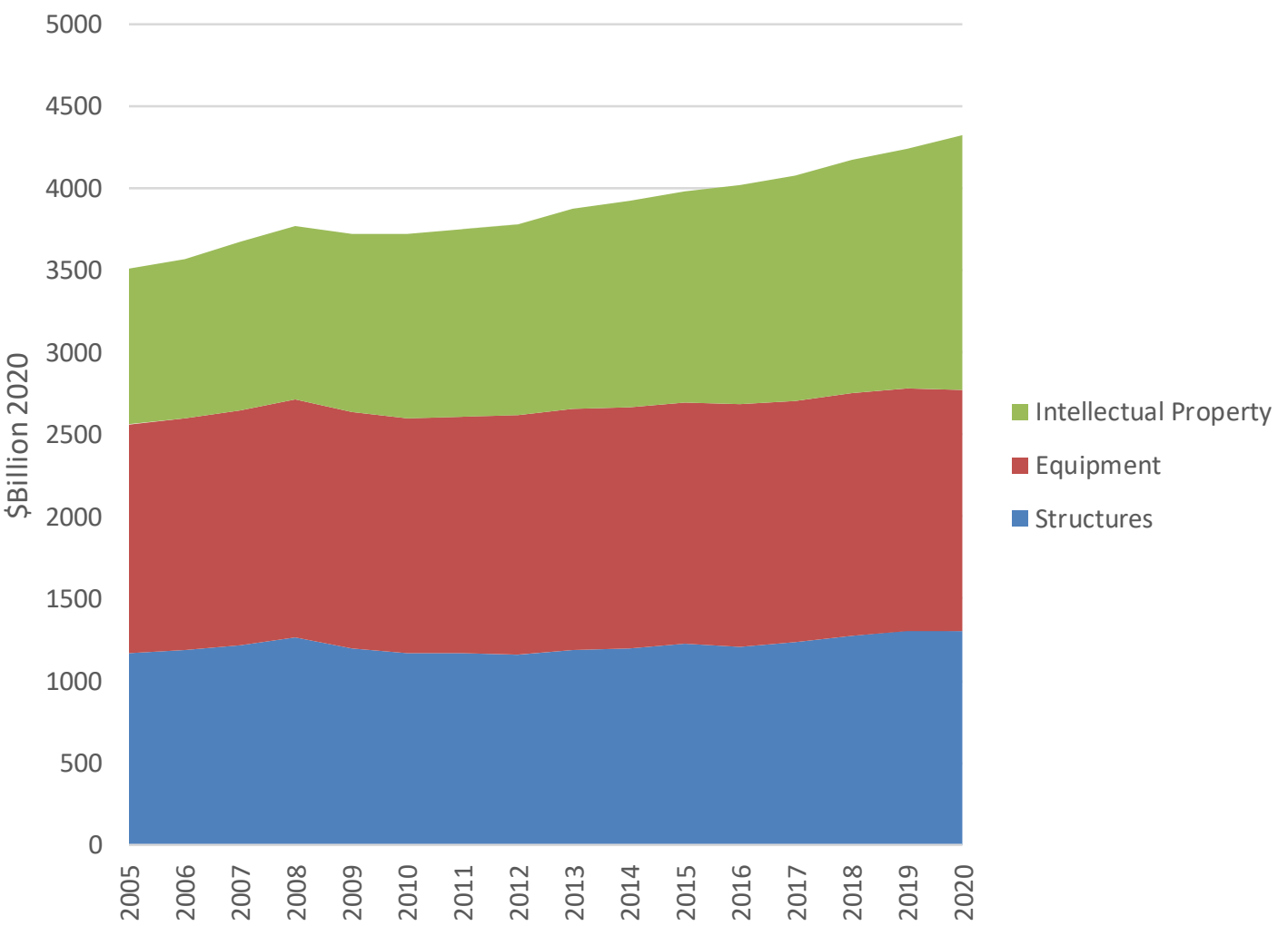

Figure 2.17: Current-Cost Net Stock in Manufacturing, by Type (2005-2020)

Adjusted using the Consumer Price Index from the Bureau of Labor Statistics

Data Source: Bureau of Economic Analysis. (2020) "Fixed Assets Accounts Tables."

https://apps.bea.gov/iTable/iTable.cfm?ReqID=10\&step=2 


\section{US Manufacturing Supply Chain}

There are many suppliers of goods and services that have a stake in manufacturing; these include resellers, providers of transportation and warehousing, raw material suppliers, suppliers of intermediate goods, and suppliers of professional services. Using data from the Annual Survey of Manufactures, ${ }^{18}$ Table 3.1 presents and Figure 3.1 maps the purchases that the manufacturing industry made for production, which is disaggregated into five categories: suppliers of services, computer hardware, software, and other costs (blue); refuse removal (gold); machinery, structures, and compensation (orange); repair of the machinery and structures (red); and suppliers of materials (green). These items all feed into the design

Table 3.1: Supply Chain Entities and Contributions, Annual Survey of Manufactures, 2019

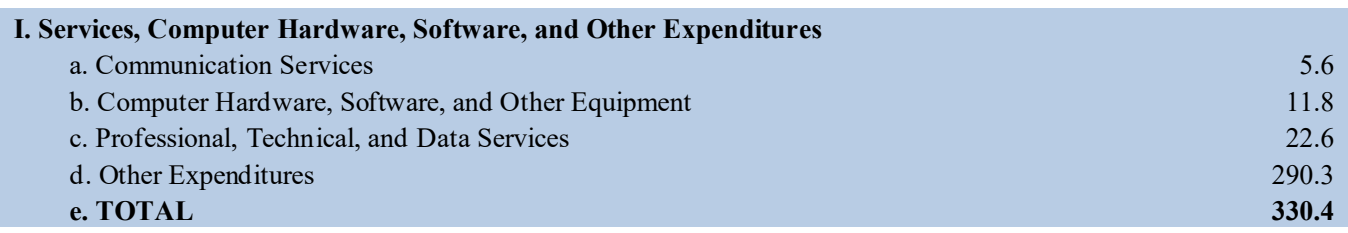

\section{Machinery, Structures, and Compensation Expenditures}

a. Payroll, Benefits, and Employment

b. Capital Expenditures: Structures (including rental)

c. Capital Expenditures: Machinery/Equipment (including rental)

\section{Suppliers of Materials Expenditures}

a. Materials, Parts, Containers, Packaging, etc... Used 2915.9

b. Contract Work and Resales

c. Purchased Fuels and Electricity

\section{Shipments}
a. Expenditures
b. Net Inventories Shipped
c. Depreciation
d. Net Income
E. TOTAL
$\mathbf{5 7 3 1 . 2}$

\section{Value Added estimates}
a. Value added calculated VI.E-VI.b-VI.A+III.a
1956.9
b. ASM Value added
2579.4
c. BEA value added
2345.8

Note: Colors correspond with those in Figure 3.1

${ }^{18}$ U.S. Census Bureau. (2021). "Annual Survey of Manufactures.” https://www.census.gov/programssurveys/asm/data/tables.html 


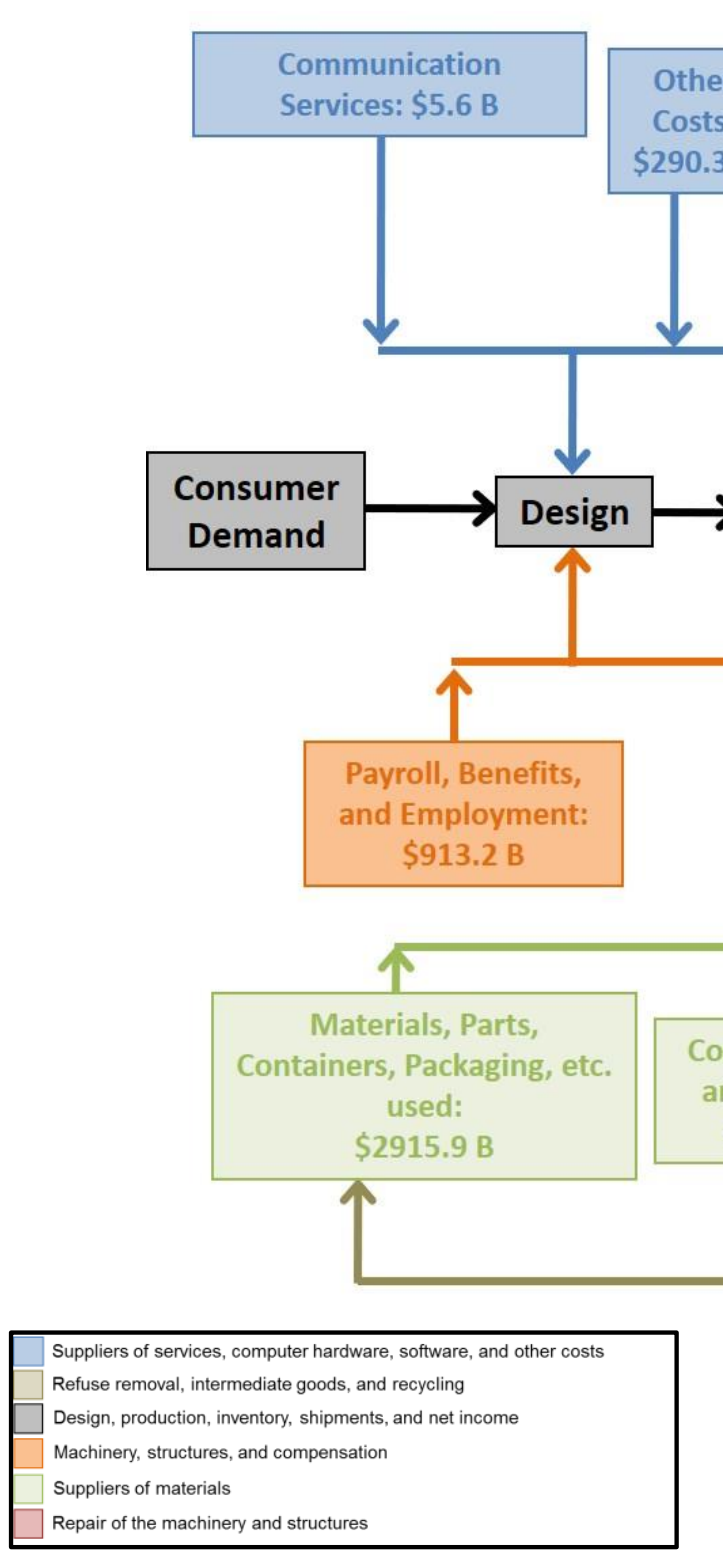

Figure 3.1: Manufacturing Supply Chain, 2019

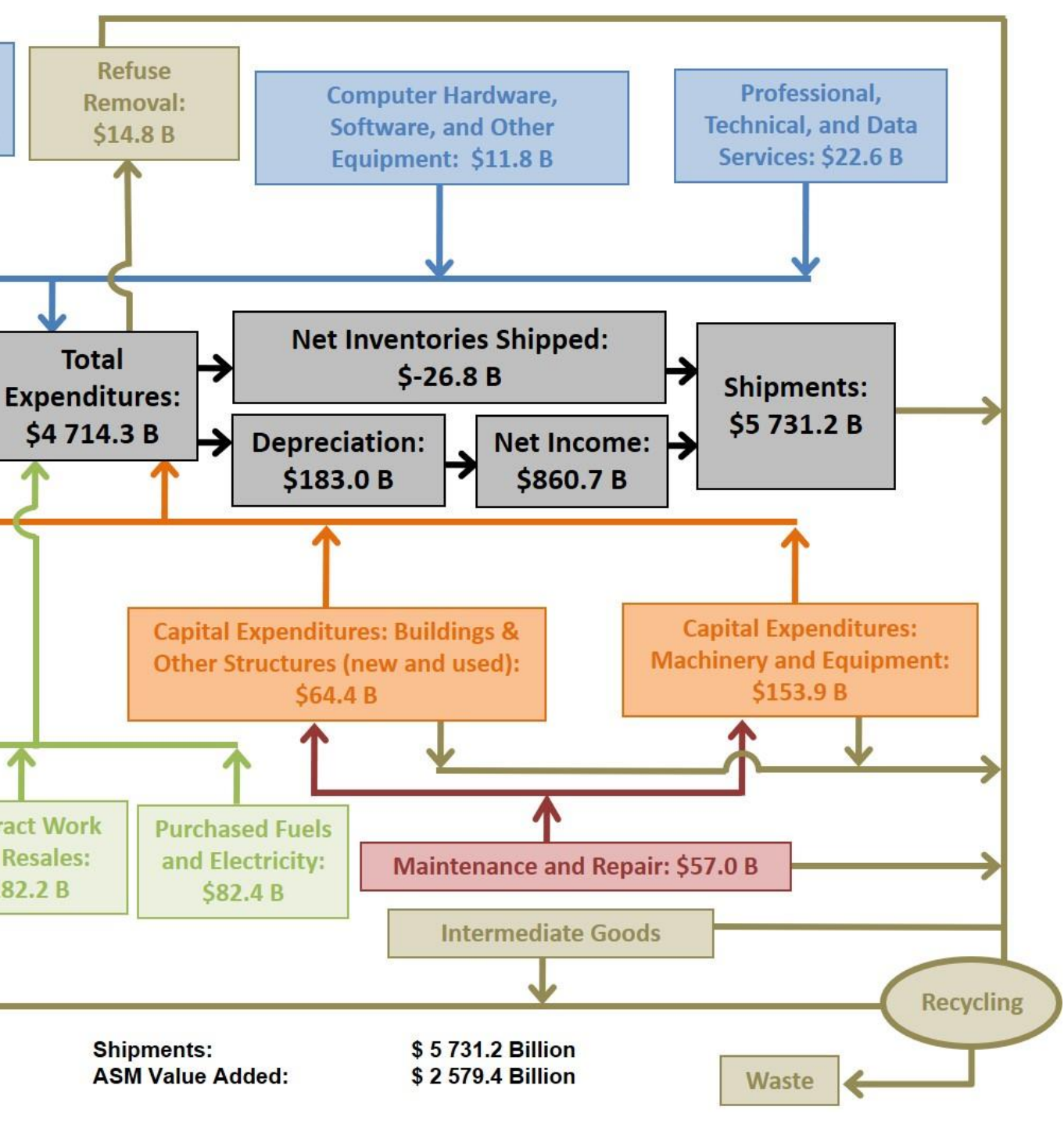

Data Source: U.S. Census Bureau. (2021). "Annual Survey of Manufactures." https://www.census.gov/programs-surveys/asm/data/tables.htmll 
and production of manufactured goods which are inventoried and/or shipped (gray). The depreciation of capital and net income is also included in Figure 3.1, which affects the market value of shipments. In addition to the stakeholders, there are also public vested interests, the end users, and financial service providers to be considered.

Direct and Indirect Manufacturing: As previously mentioned, to achieve economy-wide efficiency improvements, researchers have suggested that "the supply chain must become the focus of policy management, in contrast to the traditional emphasis on single technologies/industries." 19 As seen in Table 3.2, there is an estimated $\$ 1939$ billion in manufacturing value added with an additional $\$ 2339$ billion in indirect value added from other industries for manufacturing, as calculated using input-output analysis. ${ }^{20}$ Direct and indirect manufacturing accounts for $24.1 \%$ of total GDP.

In 2019, the U.S. imported approximately $14.7 \%$ of its intermediate goods, as seen in Table 3.3. As a proportion of output and imports (i.e., a proportion of the total inputs), intermediate imports represented $10.7 \%$. As can be seen in Table 3.3, these proportions have not changed dramatically in recent years. As seen in Table 3.4, Canada is the primary source of imported supply chain items for the U.S. with China being second.

Many of the direct costs are caused by losses due to waste or defects. Unfortunately, there is limited data and information on these losses. The research that does exist is often case studies within various industries and countries, which provide only limited insight to U.S. national trends. Tabikh estimates from survey data in Sweden that the percent of planned production time that is downtime amounts to $13.3 \%{ }^{21}$ NIST's Manufacturing

Table 3.2: Direct and Indirect Manufacturing Value Added

\begin{tabular}{llccc} 
& & \multicolumn{2}{c}{ Value Added (\$ Billion 2019) } \\
NAICS & Description & Direct & Indirect & Total \\
\hline & TOTAL U.S. GDP & & & 17775 \\
$31-33$ & Total Manufacturing* & 1939 & 2339 & 4278 \\
$333-336$ & Discrete Technology Products & 676 & 680 & 1356 \\
$313-323,327-332,337-339$ & Discrete Products & 489 & 581 & 1070 \\
$324-326$ & Process Products & 534 & 1077 & 1611 \\
$311-312$ & Food, Beverage, and Tabaco & 240 & 629 & 869 \\
\hline
\end{tabular}

* The sum of the 3 digit NAICS does not equal total manufacturing due to overlap in supply chains.

Note: Calculated using the NIST Manufacturing Cost Guide. https://www.nist.gov/services-resources/software/manufacturing-costguide.

Note: These values are calculated by taking 2012 data and adjusting it to 2019; thus, they may not match other estimates in this report.

\footnotetext{
19 Tassey Gregory. (2010) "Rationales and Mechanisms for Revitalizing U.S. Manufacturing R\&D Strategies." Journal of Technology Transfer. 35. 283-333.

${ }^{20}$ This analysis uses the Manufacturing Cost Guide. https://www.nist.gov/servicesresources/software/manufacturing-cost-guide

21 Tabikh, Mohamad. (2014). "Downtime Cost and Reduction Analysis: Survey Results." Master Thesis. KPP321. Mälardalen University. http://www.diva-portal.org/smash/get/diva2:757534/FULLTEXT01.pdf
} 
Table 3.3: Imported Intermediate Manufacturing (\$millions)

\begin{tabular}{cccccc} 
Year & $\begin{array}{c}\text { Intermediate } \\
\text { Manufacturing* }\end{array}$ & $\begin{array}{c}\text { Intermediate } \\
\text { Imports for } \\
\text { Manufacturing** }\end{array}$ & $\begin{array}{c}\text { Total } \\
\text { Manufacturing } \\
\text { Output }\end{array}$ & $\begin{array}{c}\text { Intermediate Imports as } \\
\text { a Percent of } \\
\text { Intermediates }\end{array}$ & $\begin{array}{c}\text { Intermediate imports as a } \\
\text { Percent of Total Industry } \\
\text { Output }\end{array}$ \\
\hline 2006 & 3299672 & 658321 & 5074555 & $20.0 \%$ & $11.5 \%$ \\
2007 & 3559286 & 728349 & 5385396 & $20.5 \%$ & $11.9 \%$ \\
2008 & 3692895 & 839531 & 5474517 & $22.7 \%$ & $13.3 \%$ \\
2009 & 2808930 & 536158 & 4485327 & $19.1 \%$ & $10.7 \%$ \\
2010 & 3222093 & 672003 & 4991985 & $20.9 \%$ & $11.9 \%$ \\
2011 & 3725305 & 845454 & 5562681 & $22.7 \%$ & $13.2 \%$ \\
2012 & 3844239 & 840279 & 5740953 & $21.9 \%$ & $12.8 \%$ \\
2013 & 3947424 & 819413 & 5905656 & $20.8 \%$ & $12.2 \%$ \\
2014 & 3975237 & 826780 & 5992227 & $20.8 \%$ & $12.1 \%$ \\
2015 & 3576736 & 696608 & 5673645 & $19.5 \%$ & $10.9 \%$ \\
2016 & 3453624 & 658321 & 5523480 & $19.1 \%$ & $10.6 \%$ \\
2017 & 3598067 & 706852 & 5748915 & $19.6 \%$ & $10.9 \%$ \\
2018 & 3894914 & 786224 & 6178745 & $20.2 \%$ & $11.3 \%$ \\
2019 & 5074555 & 747503 & 6230550 & $14.7 \%$ & $10.7 \%$ \\
\hline
\end{tabular}

Source Data: Bureau of Economic Analysis. (2021). Input-Output Accounts Data. https://www.bea.gov/industry/input-outputaccounts-data

* Commodities used by industries

** From the import matrix

Cost Guide, downtime amounts to $8.3 \%$ of planned production time and amounts to \$245 billion for discrete manufacturing (i.e., NAICS 321-339 excluding NAICS 324 and 325). ${ }^{22}$ In addition to downtime, defects result in additional losses. The Manufacturing Cost Guide estimates that defects amount to between $\$ 32.0$ billion and $\$ 58.6$ billion for discrete manufacturing (i.e., NAICS 321-339 excluding NAICS 324 and 325), depending on the method used for estimation. ${ }^{23}$

The USGS estimates that $15 \%$ of steel mill products end up as scrap in the manufacturing process. ${ }^{24}$ Other sources cite that at least $25 \%$ of liquid steel and $40 \%$ of liquid aluminum does not make it into a finished product due primarily to metal quality ( $25 \%$ of steel loss and $40 \%$ of aluminum loss), the shape produced ${ }^{25}$ (10\% to $15 \%$ of loss), and defects in the manufacturing processes (5\% of loss). ${ }^{26}$ Material losses mean there is the possibility of producing the same goods using less material, which could have rippling effects up and down the supply chain. There would be reductions in the burden of transportation, material handling, machinery, inventory costs, and energy use along with many other activities associated with handling and altering materials.

\footnotetext{
${ }^{22}$ Thomas, Douglas. (2020). Manufacturing Cost Guide. https://www.nist.gov/servicesresources/software/manufacturing-cost-guide

23 Thomas, Douglas. (2020). Manufacturing Cost Guide. https://www.nist.gov/servicesresources/software/manufacturing-cost-guide

${ }^{24}$ Fenton, M. D. (2001) "Iron and Steel Recycling in the United States in 1998." Report 01-224. U.S. Geological Survey: 3. https://pubs.usgs.gov/of/2001/of01-224/

25 The steel and aluminum industry often produce standard shapes rather than customized shapes tailored to specific products. This results in needing to cut away some portion of material, which ends up as scrap. ${ }^{26}$ Allwood, J. M. \& Cullen, J. M. (2012). Sustainable Materials with Both Eyes Open. Cambridge Ltd. 185. http://www.withbotheyesopen.com/
} 
Table 3.4: Percent of U.S. Manufacturing Industry Supply Chain, by Country of Origin (2014)

\begin{tabular}{lc} 
Country & $\begin{array}{c}\text { US } \\
\text { Manufacturing } \\
\text { Supply Chain } \\
\text { (percent) }\end{array}$ \\
\hline USA & 83.0 \\
CAN & 3.1 \\
CHN & 1.8 \\
MEX & 1.5 \\
DEU & 0.8 \\
JPN & 0.8 \\
GBR & 0.5 \\
KOR & 0.5 \\
RUS & 0.4 \\
ROW & 7.6
\end{tabular}

Note: Calculated using NIST. Manufacturing Cost Guide. https://www.nist.gov/services-resources/software/manufacturing-cost-guide.

Another source of losses can be found in cybercrime where criminals can disrupt production and/or steal intellectual property. The Manufacturing Cost Guide estimates that manufacturers lost between $\$ 8.9$ billion and $\$ 38.6$ billion due to cybercrime.

Manufacturing costs also accumulate in assets such as buildings, machinery, and inventory. In addition to the estimates provided in Figure 2.14, Figure 2.15, Figure 2.16, and Figure 2.17, data on assets is published periodically in the Economic Census. As seen in Table 3.5, total depreciable assets amount to \$3.4 trillion with $\$ 2.7$ trillion being machinery and equipment.

A frequently invoked axiom suggests that roughly $80 \%$ of a problem is due to $20 \%$ of the cause, a phenomenon referred to as the Pareto principle. ${ }^{27}$ That is, a small portion of the cause accounts for a large portion of the problem. Identifying that small portion can

Table 3.5: Depreciable Assets and the Rate of Change, 2017 (\$million 2017)

\begin{tabular}{|c|c|c|c|}
\hline & $\begin{array}{c}\text { Buildings and } \\
\text { Structures }\end{array}$ & $\begin{array}{l}\text { Machinery } \\
\text { and } \\
\text { Equipment }\end{array}$ & Total \\
\hline Gross value of depreciable assets (acquisition costs), beginning of year & $661841^{*}$ & $2645636^{*}$ & 3307476 \\
\hline Capital Expenditures (added to assets) & 33705 & 134733 & 168438 \\
\hline Retirements (subtracted from assets) & $11597 *$ & $46358^{*}$ & 57955 \\
\hline Gross value of depreciable assets (acquisition costs, end of year) & 683949 & 2734011 & 3417960 \\
\hline Percent of depreciable assets that are new (end of year) & & & $4.9 \%$ \\
\hline
\end{tabular}

Source: U.S. Census Bureau. (2020) 2017 Economic Census. https://www.census.gov/data/tables/2017/econ/economic-census/naicssector-31-33.html

${ }^{27}$ Hopp, Wallace J. and Mark L. Spearman. (2008). Factory Physics. Third Edition. (Waveland Press, Long Grove, IL. 
facilitate making large efficiency improvements in manufacturing. Industries are categories of production activities. A larger industry suggests that there is more of a particular type of activity occurring; thus, an increase in productivity has a larger impact for a large cost area than a small cost area. Additionally, statistical evidence suggests that a dollar of research and development in a large cost supply chain entity has a higher return on investment than a small cost one. ${ }^{28}$ Table 3.6 provides a list of the top $20 \%$ of domestic supply chain industries for U.S. manufacturing by value added. Various forms of energy production and/or transmission appear in the top $20 \%$. Various forms of transportation are also present along with the management of companies and enterprises. Table 3.7 provides compensation by occupation and management occupations is the $2^{\text {nd }}$ largest.

Figure 3.2 shows a selection of expenditures for various manufacturing subsectors from the Annual Survey of Manufactures. The cost items for each industry correspond with those in Figure 3.1 and Table 3.1. It is important to note that the costs in Figure 3.2 are broken-up differently than those in the input-output analyses. The input-output analysis breaks costs into industries. For example, the value added for the coal used to produce electricity consumed by manufacturing is found in the mining industry. The data from the Annual Survey of Manufactures in Figure 3.2 lumps all the costs for electricity together.

\footnotetext{
${ }^{28}$ Thomas, Douglas. (2018). "The Effect of Flow Time on Productivity and Production." National Institute of Standards and Technology. Advanced Manufacturing Series 100-25. https://nvlpubs.nist.gov/nistpubs/ams/NIST.AMS.100-25.pdf
} 
Table 3.6: Top $20 \%$ of Domestic Supply Chain Entities, Value Added

\begin{tabular}{|c|c|c|c|c|c|}
\hline Code & Industry Description & $\begin{array}{c}\text { \$Billion } \\
2019\end{array}$ & Code & Industry Description & $\begin{array}{c}\text { \$Billion } \\
2019\end{array}$ \\
\hline 324110 & Petroleum refineries & 596.1 & 482000 & Rail transportation & 26.6 \\
\hline 211000 & Oil and gas extraction & 516.1 & 325180 & Other Basic Inorganic Chemical Manufacturing & 26.0 \\
\hline 550000 & Management of companies and enterprises & 128.5 & $112 \mathrm{~A} 00$ & Animal production, except cattle and poultry and eggs & 26.0 \\
\hline 325412 & Pharmaceutical preparation manufacturing & 83.0 & 336390 & Other Motor Vehicle Parts Manufacturing & 25.8 \\
\hline 336112 & Light truck and utility vehicle manufacturing & 78.5 & 339112 & Surgical and medical instrument manufacturing & 25.7 \\
\hline 424A00 & Other nondurable goods merchant wholesalers & 77.5 & 533000 & Lessors of nonfinancial intangible assets & 25.3 \\
\hline 336411 & Aircraft manufacturing & 76.6 & 334510 & Electromedical and electrotherapeutic apparatus manufacturing & 24.7 \\
\hline 423A00 & Other durable goods merchant wholesalers & 68.9 & $522 \mathrm{~A} 00$ & Nondepository credit intermediation and related activities & 24.7 \\
\hline 221100 & Electric power generation, transmission, and distribution & 63.4 & 322120 & Paper mills & 24.6 \\
\hline 331110 & Iron and steel mills and ferroalloy manufacturing & 59.8 & $3259 A 0$ & All other chemical product and preparation manufacturing & 24.4 \\
\hline 325110 & Petrochemical manufacturing & 57.2 & $5241 X X$ & Insurance carriers, except direct life & 24.1 \\
\hline 484000 & Truck transportation & 56.7 & $1111 \mathrm{~A} 0$ & Oilseed farming & 24.0 \\
\hline 5310RE & Other real estate & 55.3 & 486000 & Pipeline transportation & 23.9 \\
\hline 325190 & Other basic organic chemical manufacturing & 54.9 & 541200 & Accounting, tax preparation, bookkeeping, and payroll services & 23.7 \\
\hline 312200 & Tobacco product manufacturing & 48.7 & $21311 \mathrm{~A}$ & Other support activities for mining & 23.3 \\
\hline 336412 & Aircraft engine and engine parts manufacturing & 48.6 & 311810 & Bread and bakery product manufacturing & 22.5 \\
\hline 334413 & Semiconductor and related device manufacturing & 48.1 & 333120 & Construction machinery manufacturing & 22.4 \\
\hline 334511 & Search, detection, and navigation instruments manufacturing & 42.7 & 561700 & Services to buildings and dwellings & 22.1 \\
\hline 326190 & Other plastics product manufacturing & 42.6 & 230301 & Nonresidential maintenance and repair & 21.4 \\
\hline 323110 & Printing & 41.8 & 322210 & Paperboard container manufacturing & 21.4 \\
\hline $52 \mathrm{~A} 000$ & Monetary authorities and depository credit intermediation & 38.7 & 339113 & Surgical appliance and supplies manufacturing & 21.3 \\
\hline 424700 & Petroleum and petroleum products & 37.5 & 332310 & Plate work and fabricated structural product manufacturing & 21.2 \\
\hline 325211 & Plastics material and resin manufacturing & 36.9 & $33291 \mathrm{~A}$ & Valve and fittings other than plumbing & 20.8 \\
\hline 1111B0 & Grain farming & 36.3 & 423600 & Household appliances and electrical and electronic goods & 20.3 \\
\hline 1121A0 & Cattle ranching and farming & 34.4 & 333415 & Air conditioning, refrigeration, and warm air heating equipment & 20.1 \\
\hline 423800 & Machinery, equipment, and supplies & 33.1 & 331200 & Steel product manufacturing from purchased steel & 19.6 \\
\hline 334220 & Broadcast and wireless communications equipment & 31.1 & 325620 & Toilet preparation manufacturing & 19.6 \\
\hline 561300 & Employment services & 31.0 & 333130 & Mining and oil and gas field machinery manufacturing & 19.4 \\
\hline 336111 & Automobile manufacturing & 30.1 & 524200 & Insurance agencies, brokerages, and related activities & 19.2 \\
\hline 541300 & Architectural, engineering, and related services & 29.4 & 332320 & Ornamental and architectural metal products manufacturing & 19.1 \\
\hline 325610 & Soap and cleaning compound manufacturing & 29.0 & 333111 & Farm machinery and equipment manufacturing & 19.1 \\
\hline 424400 & Grocery and related product wholesalers & 28.6 & $33441 \mathrm{~A}$ & Other electronic component manufacturing & 19.0 \\
\hline 336413 & Other aircraft parts and auxiliary equipment manufacturing & 28.5 & 326110 & Plastics packaging materials and unlaminated film and sheet manufacturing & 18.9 \\
\hline 325310 & Fertilizer manufacturing & 28.5 & 332800 & Coating, engraving, heat treating and allied activities & 18.5 \\
\hline 325414 & Biological product (except diagnostic) manufacturing & 28.4 & 331490 & Nonferrous metal (except copper and aluminum) & 18.1 \\
\hline 541100 & Legal services & 28.4 & 423100 & Motor vehicle and motor vehicle parts and supplies & 18.1 \\
\hline 332710 & Machine shops & 28.1 & 541610 & Management consulting services & 17.8 \\
\hline 31161A & Animal (except poultry) slaughtering, rendering, and processing & 28.1 & $5419 A 0$ & All other miscellaneous professional, scientific, and technical services & 17.7 \\
\hline
\end{tabular}

Note: Calculated using the NIST Manufacturing Cost Guide. https://www.nist.gov/services-

resources/software/manufacturing-cost-guide. 
Table 3.7: Total Domestic Compensation for Manufacturing and its Supply Chain, by Occupation SOC $\$ 2019$

\begin{tabular}{ll} 
Code Description & Billion \\
\hline 000000 & All
\end{tabular}

$000000 \quad$ All Occupations 1822.7

$110000 \quad$ Management Occupations $\quad 277.2$

$130000 \quad$ Business and Financial Operations Occupations 144.3

$150000 \quad$ Computer and Mathematical Occupations $\quad 103.7$

$170000 \quad$ Architecture and Engineering Occupations $\quad 141.8$

190000 Life, Physical, and Social Science Occupations

210000 Community and Social Service Occupations 1.0

230000 Legal Occupations 18.7

$250000 \quad$ Education, Training, and Library Occupations 1.6

270000 Arts, Design, Entertainment, Sports, and Media Occupations

$290000 \quad$ Healthcare Practitioners and Technical Occupations

$310000 \quad$ Healthcare Support Occupations 1.3

$330000 \quad$ Protective Service Occupations $\quad 6.8$

$350000 \quad$ Food Preparation and Serving Related Occupations 11.1

$370000 \quad$ Building and Grounds Cleaning and Maintenance Occupations $\quad 16.2$

$390000 \quad$ Personal Care and Service Occupations 2.5

$410000 \quad$ Sales and Related Occupations $\quad 117.9$

$430000 \quad$ Office and Administrative Support Occupations 180.7

$450000 \quad$ Farming, Fishing, and Forestry Occupations 16.6

$470000 \quad$ Construction and Extraction Occupations 43.6

$490000 \quad$ Installation, Maintenance, and Repair Occupations 101.3

$510000 \quad$ Production Occupations 433.2

$530000 \quad$ Transportation and Material Moving Occupations 144.9

TOTAL 3642.3

Note: Calculated using the NIST Manufacturing Cost Guide. https://www.nist.gov/services-

resources/software/manufacturing-cost-guide. 


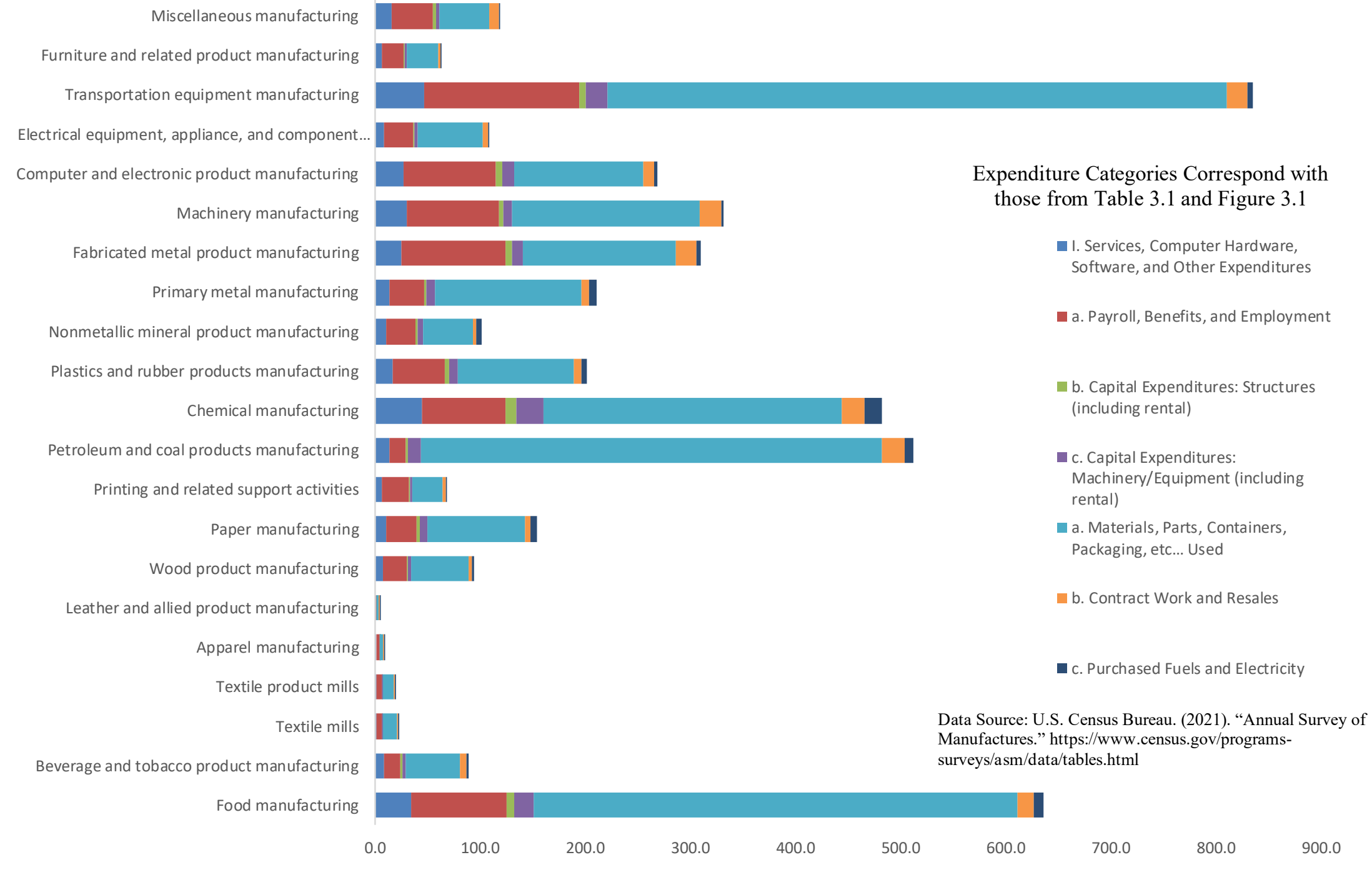

Figure 3.2 Expenditures by Subsector, Annual Survey of Manufactures 


\section{Employment, Compensation, Profits, and Productivity}

The Annual Survey of Manufactures estimates that there were 11.5 million employees in the manufacturing industry in 2019, which is the most recent data available (see Table 4.1). The Current Population Survey estimates that there were 15.7 million manufacturing employees in 2019 and the Current Employment Statistics estimates 12.2 million employees in 2020, the most recent data available (see Table 4.2 and Table 4.3). According to data in Table 4.2, manufacturing accounted for $9.4 \%$ of total employment. Each of these estimates has its own method for how the data was acquired and its own definition of employment. The Current Population Survey considers an employed person to be any individual who did any work for pay or profit during the survey reference week or were absent from their job because they were ill, on vacation, or taking leave for some other reason. It also includes individuals who completed at least 15 hours of unpaid work in a family-owned enterprise operated by someone in their household. In contrast, the Current Employment Statistics specifically exclude proprietors, self-employed, and unpaid family or volunteer workers. Therefore, the estimates from the Current Employment Statistics are lower than the Current Population Survey estimates. Additionally, the Current Employment Statistics include temporary and intermittent employees. The Annual Survey of Manufactures considers an employee to include all full-time and part-time employees on the payrolls of operating establishments during any part of the pay period being surveyed excluding temporary staffing obtained through a staffing service. It also excludes proprietors along with partners of unincorporated businesses.

Table 4.1: Employment, Annual Survey of Manufactures

\begin{tabular}{|c|c|c|c|}
\hline NAICS & Description & 2018 & 2019 \\
\hline 311 & Food manufacturing & 1494203 & 1487229 \\
\hline 312 & Beverage and tobacco product manufacturing & 221186 & 218916 \\
\hline 313 & Textile mills & 90474 & 87668 \\
\hline 314 & Textile product mills & 102395 & 102880 \\
\hline 315 & Apparel manufacturing & 78525 & 73739 \\
\hline 316 & Leather and allied product manufacturing & 26035 & 26082 \\
\hline 321 & Wood product manufacturing & 402450 & 391148 \\
\hline 322 & Paper manufacturing & 328768 & 332660 \\
\hline 323 & Printing and related support activities & 420133 & 394834 \\
\hline 324 & Petroleum and coal products manufacturing & 107735 & 106669 \\
\hline 325 & Chemical manufacturing & 761701 & 751137 \\
\hline 326 & Plastics and rubber products manufacturing & 775936 & 768886 \\
\hline 327 & Nonmetallic mineral product manufacturing & 401203 & 390998 \\
\hline 331 & Primary metal manufacturing & 365673 & 368190 \\
\hline 332 & Fabricated metal product manufacturing & 1391265 & 1384342 \\
\hline 333 & Machinery manufacturing & 1042126 & 1042185 \\
\hline 334 & Computer and electronic product manufacturing & 797788 & 789468 \\
\hline 335 & Electrical equipment, appliance, and component manufacturing & 344926 & 346043 \\
\hline 336 & Transportation equipment manufacturing & 1569237 & 1552433 \\
\hline 337 & Furniture and related product manufacturing & 384369 & 360820 \\
\hline 339 & Miscellaneous manufacturing & 527166 & 531085 \\
\hline & & 11633294 & 11507412 \\
\hline
\end{tabular}

Data Source: Data Source: U.S. Census Bureau. (2021). “Annual Survey of Manufactures.” https://www.census.gov/programssurveys/asm/data/tables.html 
Table 4.2: Employment by Industry for 2018 and 2019 (Thousands): Current Population Survey

\begin{tabular}{|c|c|c|c|c|}
\hline Industry & $\begin{array}{c}\text { Total Employed } \\
2018\end{array}$ & $\begin{array}{c}\text { Total Employed } \\
2019\end{array}$ & $\begin{array}{c}\text { Employment } \\
\text { Change }\end{array}$ & $\begin{array}{l}\text { Percent } \\
\text { Change }\end{array}$ \\
\hline Mining & 784 & 750 & -34 & $-4.3 \%$ \\
\hline Construction & 11181 & 11373 & 192 & $1.7 \%$ \\
\hline Manufacturing & 15560 & 15741 & 181 & $1.2 \%$ \\
\hline Wholesale and Retail Trade & 20270 & 19742 & -528 & $-2.6 \%$ \\
\hline Transportation and Utilities & 8551 & 8991 & 440 & $5.1 \%$ \\
\hline Information & 2919 & 2766 & -153 & $-5.2 \%$ \\
\hline Financial Activities & 10649 & 10765 & 116 & $1.1 \%$ \\
\hline Professional and Business Services & 18950 & 19606 & 656 & $3.5 \%$ \\
\hline Education and Health Services & 35043 & 35894 & 851 & $2.4 \%$ \\
\hline Leisure and Hospitality & 14268 & 14643 & 375 & $2.6 \%$ \\
\hline Other Services & 7742 & 7617 & -125 & $-1.6 \%$ \\
\hline Public Administration & 7419 & 7225 & -194 & $-2.6 \%$ \\
\hline Agriculture & 2425 & 2425 & 0 & $0.0 \%$ \\
\hline TOTAL* & 155761 & 157538 & 1777 & $1.1 \%$ \\
\hline
\end{tabular}

Table 4.3: Manufacturing Employment (Thousands): Current Employment Statistics

\begin{tabular}{lccc} 
& 2019 & 2020 & Percent Change \\
\hline Manufacturing & 12817 & 12179 & $-5.0 \%$ \\
Durable Goods & 8039 & 7580 & $-5.7 \%$ \\
Nondurable Goods & 4778 & 4600 & $-3.7 \%$ \\
\hline
\end{tabular}

Source: Bureau of Labor Statistics. (2021) Current Employment Statistics.

http://www.bls.gov/ces/home.htm

Between January 2005 and January 2010, manufacturing employment declined by $19.6 \%$, as seen in Figure 4.1. As of January 2020, employment was still $10.3 \%$ below its 2005 level. In times of financial difficulty, large purchases are often delayed or determined to be unnecessary. Thus, it would be expected that during the late 2000's recession durable goods would decline more than nondurable goods, which is what happened during this recession. The other major decline in manufacturing employment was during the pandemic. In April of 2020, manufacturing was $19.9 \%$ below its 2005 level. By August 2021, manufacturing employment had risen to $12.9 \%$ below its 2005 level. However, there are a substantial number of job openings in manufacturing as seen in Figure 4.1. If these openings were filled, it would raise employment above prepandemic levels and would equate to a $7 \%$ increase in manufacturing employment.

The employees that work in manufacturing offer their time and, in some cases, risk their personal safety in return for compensation. In terms of safety, the number of fatal injuries decreased $15.1 \%$ between 2018 and 2019 (see Table 4.4). Nonfatal injuries decreased as did the injury rate (see Table 4.5). However, the incident rate for nonfatal injuries in manufacturing remains higher than that for all private industry. As illustrated in Figure 4.2 , fatalities, injuries, and the injury rate have a five-year compound growth rate of $0.8 \%,-2.7 \%$, and $-3.8 \%$ respectively. 
During the late 2000s recession, the average number of hours worked per week declined, as seen in Figure 4.3. Unlike employment, however, the number of hours worked per week returned to its pre-recession levels or slightly higher. Average wages increased significantly during the late 2000's recession and 2020 decline of GDP, as can be seen in Figure 4.4. This is likely because low wage earners are disproportionately impacted by employment reductions, which suggests that high wage earners not only receive more pay, they also have more job security. Average hours also dropped during the pandemic

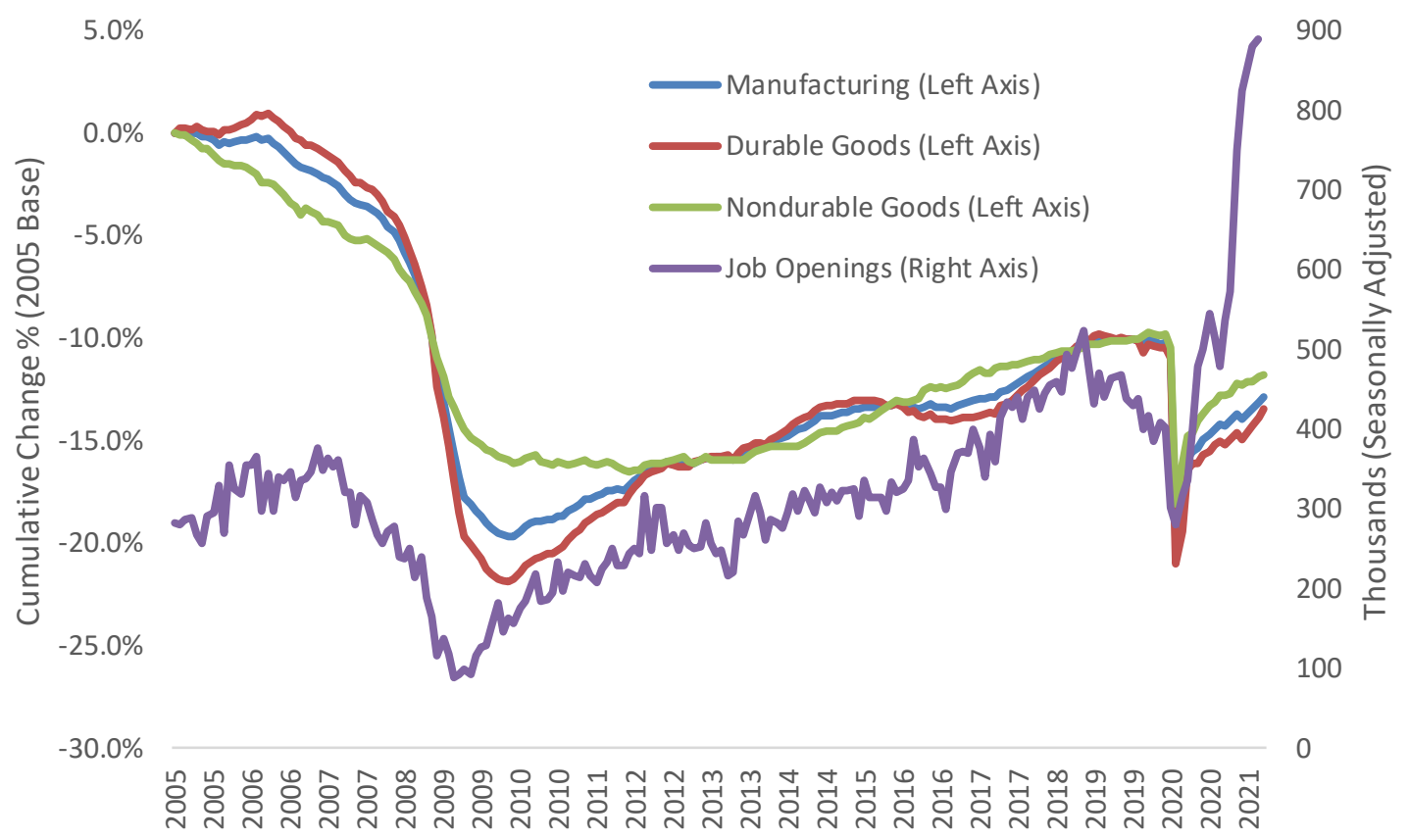

Figure 4.1: Cumulative Change in Percent in Manufacturing Employment (Seasonally Adjusted) and Number of Job Openings (seasonally Adjusted), 2005-2021

Source: Bureau of Labor Statistics. (2021) Current Employment Statistics. http://www.bls.gov/ces/ and Bureau of Labor Statistics. (2021) Job Openings and Labor Turnover Survey. https://www.bls.gov/jlt/

Table 4.4: Fatal Occupational Injuries by Event or Exposure

\begin{tabular}{|c|c|c|c|c|c|c|c|c|}
\hline & & Total & $\begin{array}{l}\text { Violence and } \\
\text { other injuries } \\
\text { by persons or } \\
\text { animals }\end{array}$ & $\begin{array}{l}\text { Transportation } \\
\text { Incidents }\end{array}$ & $\begin{array}{l}\text { fires and } \\
\text { explosions }\end{array}$ & $\begin{array}{l}\text { Falls, } \\
\text { slips, } \\
\text { trips }\end{array}$ & $\begin{array}{l}\text { exposure to } \\
\text { harmful sub- } \\
\text { stances or } \\
\text { environments }\end{array}$ & $\begin{array}{l}\text { Contact } \\
\text { with } \\
\text { objects } \\
\text { and } \\
\text { equipment }\end{array}$ \\
\hline \multirow{2}{*}{$\stackrel{\infty}{\stackrel{\sim}{\sim}}$} & Total & 5250 & 828 & 2080 & 115 & 791 & 621 & 786 \\
\hline & Manufacturing & 343 & 40 & 83 & 16 & 46 & 50 & 106 \\
\hline \multirow{2}{*}{$\stackrel{a}{\stackrel{2}{े}}$} & Total & 5333 & 841 & 2122 & 99 & 880 & 642 & 732 \\
\hline & Manufacturing & 336 & 34 & 99 & 10 & 61 & 40 & 90 \\
\hline \multirow{2}{*}{ 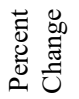 } & Total & $1.6 \%$ & $1.6 \%$ & $2.0 \%$ & $-13.9 \%$ & $11.3 \%$ & $3.4 \%$ & $-6.9 \%$ \\
\hline & Manufacturing & $-2.0 \%$ & $-15.0 \%$ & $19.3 \%$ & $-37.5 \%$ & $32.6 \%$ & $-20.0 \%$ & $-15.1 \%$ \\
\hline
\end{tabular}

Source: Bureau of Labor Statistics. (2021) Census of Fatal Occupational Injuries. "Industry by Event or Exposure."

$<$ http://stats.bls.gov/iif/oshcfoil.htm> 
Table 4.5: Total Recordable Cases of Nonfatal Injuries and Illnesses Involving Days Away from Work

\begin{tabular}{|c|c|c|c|c|}
\hline & & 2018 & 2019 & Percent Change \\
\hline$\stackrel{1}{\Xi} \cdot \stackrel{\infty}{\Xi}$ & Incident Rate per 100 full time workers* & 3.4 & 3.3 & $-2.9 \%$ \\
\hline$\sum \underset{\tilde{c}}{\tilde{U}}$ & Total Recordable Cases (thousands) & 430.3 & 421.4 & $-2.1 \%$ \\
\hline 总 & Incident Rate per 100 full time workers* & 2.8 & 2.8 & $0.0 \%$ \\
\hline$\equiv \Xi$ & Total Recordable Cases (thousands) & 2834.5 & 2814.0 & $-0.7 \%$ \\
\hline
\end{tabular}

Source: Bureau of Labor Statistics. (2021) Injuries, Illness, and Fatalities Program. http://www.bls.gov/iif/

* The incidence rates represent the number of injuries and illnesses per 100 full-time workers and were calculated as: $(\mathrm{N} / \mathrm{EH}) \times 200,000$, where

$\mathrm{N}=$ number of injuries and illnesses

$\mathrm{EH}=$ total hours worked by all employees during the calendar year

200,000 = base for 100 equivalent full-time workers (working 40 hours per week, 50 weeks per year)

and has largely returned to precession levels. Similar to the late 2000's recession, during the pandemic wages increased while hours and employment decreased.

The compound annual growth rate in real dollars for private sector wages was $1.0 \%$ between July 2016 and July 2021 while it was $0.2 \%$ for manufacturing. As illustrated in Figure 4.5, employee compensation in manufacturing, which includes benefits, has had a five-year compound annual growth of $-1.2 \%$, but remains above total private industry compensation. It is difficult to conclude much from the growth in average wages and compensation, as much of it seems to be driven by changes in employment due to recession activity and the pandemic.

For those that invest in manufacturing, nonfarm proprietors' income for manufacturing has had a five-year compound annual growth rate of $-4.3 \%$, as illustrated in Figure 4.6. Corporate profits have had a five-year compound annual growth of $-5.8 \%$.

An important aspect of manufacturing is the efficiency and productivity with which resources are used. The Bureau of Labor Statistics provides an index of labor productivity and multifactor productivity. Labor productivity for manufacturing decreased slightly from 2019 to 2020, as seen in Figure 4.7. The five-year compound annual growth is $-0.5 \%$. The Bureau of Labor Statistics multifactor productivity is "a measure of economic performance that compares the amount of goods and services produced (output) to the amount of combined inputs used to produce those goods and services. Inputs can include labor, capital, energy, materials, and purchased services." For U.S. manufacturing, multifactor productivity decreased $2.0 \%$ from 2018 to 2019 and has had a downward trend in recent years with a 5 -year annual compound growth of $-0.8 \%$, as illustrated in Figure 4.8. Productivity in the U.S. is relatively high compared to other countries. As illustrated in Figure 4.9, the U.S. is ranked seventh in output per hour among 133 countries using data from the Conference Board. ${ }^{29}$

${ }^{29}$ Conference Board. (2020) Total Economy Database: Output, Labor and Labor Productivity. https://www.conference-board.org/data/economydatabase/index.cfm?id=27762 


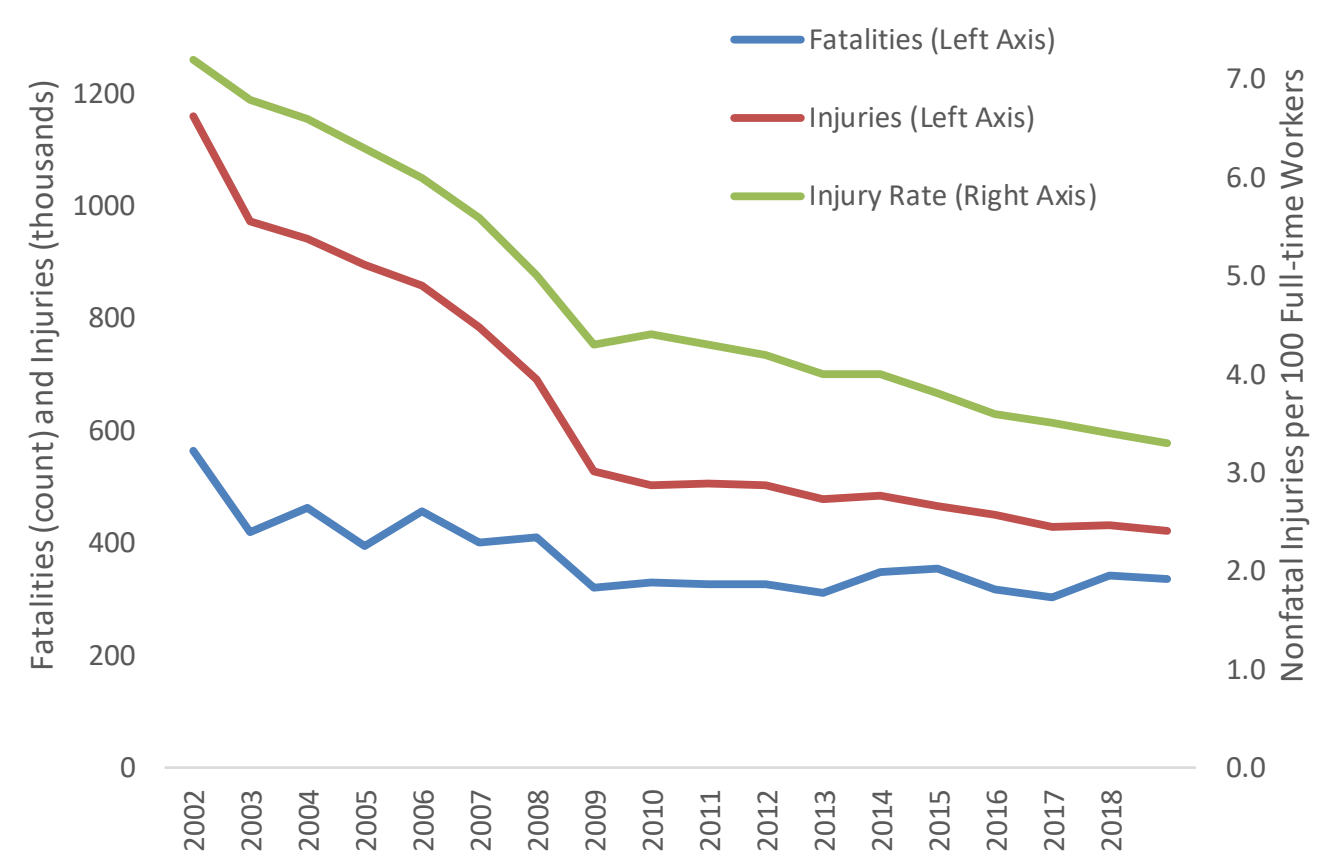

Figure 4.2: Manufacturing Fatalities and Injuries

Source: Bureau of Labor Statistics. 2021. Injuries, Illness, and Fatalities Program. http://www.bls.gov/iif/

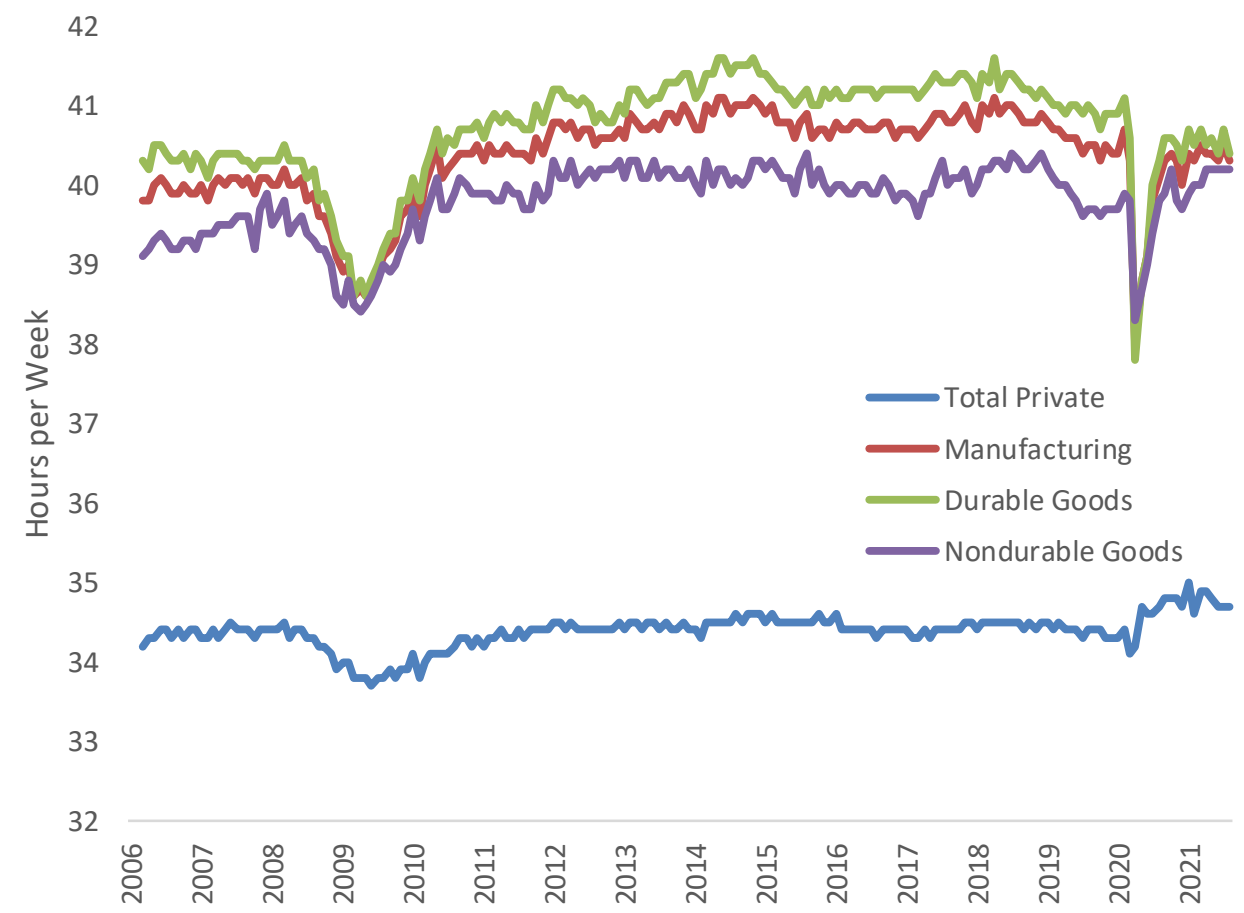

Figure 4.3: Average Weekly Hours for All Employees (Seasonally Adjusted)

Source: Bureau of Labor Statistics. (2021) Current Employment Statistics. http://www.bls.gov/ces/home.htm 


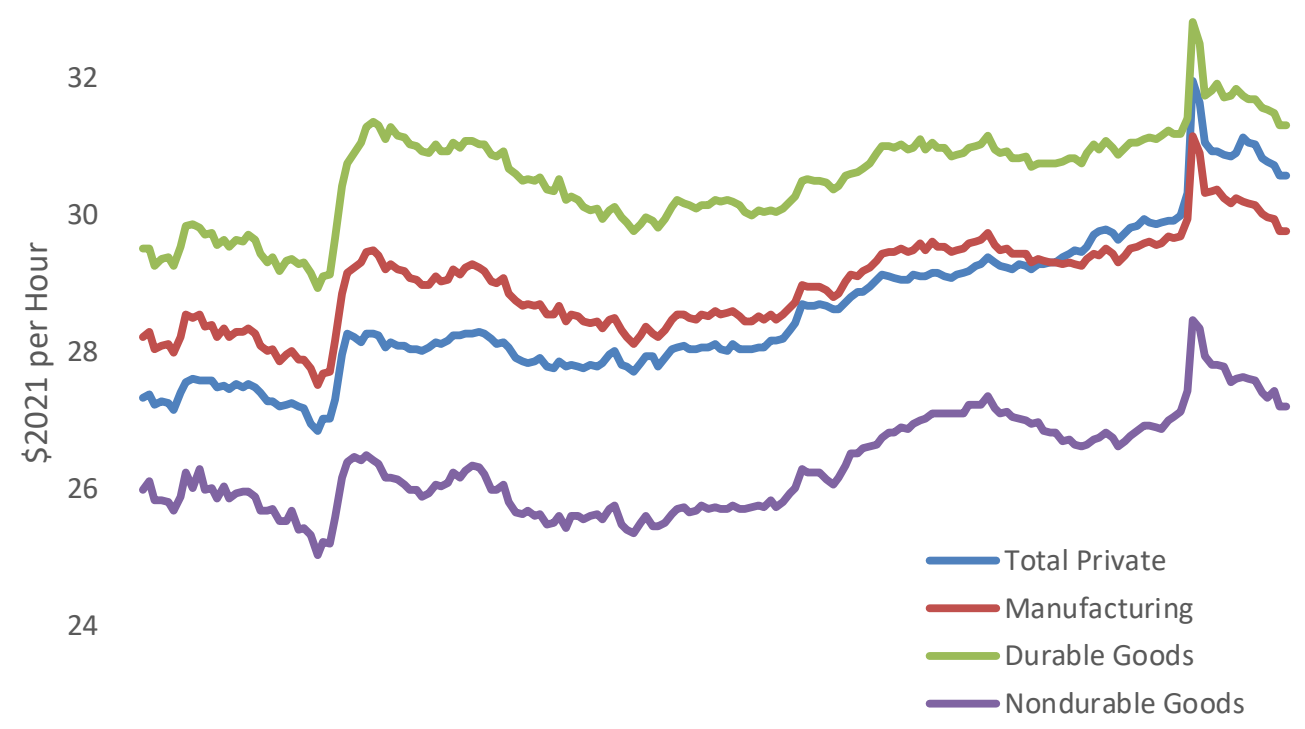

22

\begin{tabular}{|c|c|c|c|c|c|c|c|c|c|c|c|c|c|}
\hline 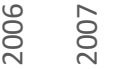 & ర্ & 옹 & 옹 & ్ㅗㅇ & ్ㅗㅇ & $\stackrel{m}{\stackrel{N}{\sim}}$ & 永 & 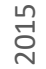 & $\begin{array}{l}0 \\
\stackrel{-}{0} \\
\text { N }\end{array}$ & స్ర & $\stackrel{\infty}{\stackrel{్}{్}}$ & 옹 & ్ి \\
\hline
\end{tabular}

Figure 4.4: Average Hourly Wages for Manufacturing and Private Industry (Seasonally Adjusted) Source: Bureau of Labor Statistics. (2021) Current Employment Statistics. http://www.bls.gov/ces/home.htm

Adjusted using the CPI for all consumers. Bureau of Labor Statistics. Consumer Price Index. (2021) https://www.bls.gov/cpi/data.htm

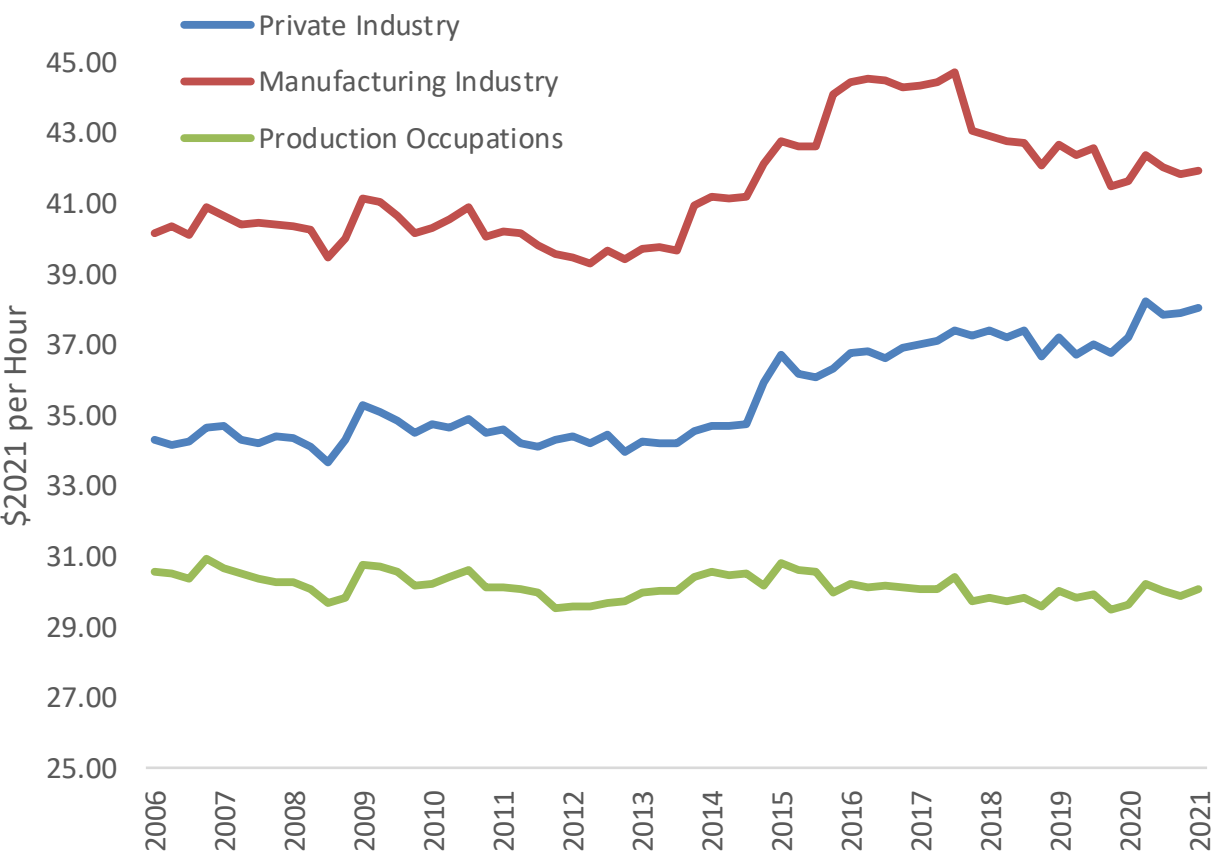

Figure 4.5: Employee Compensation (Hourly)

Source: Bureau of Labor Statistics. (2021) National Compensation Survey. http://www.bls.gov/ncs/ 
Adjusted using the Consumer Price Index for all consumers from the Bureau of Labor Statistics.

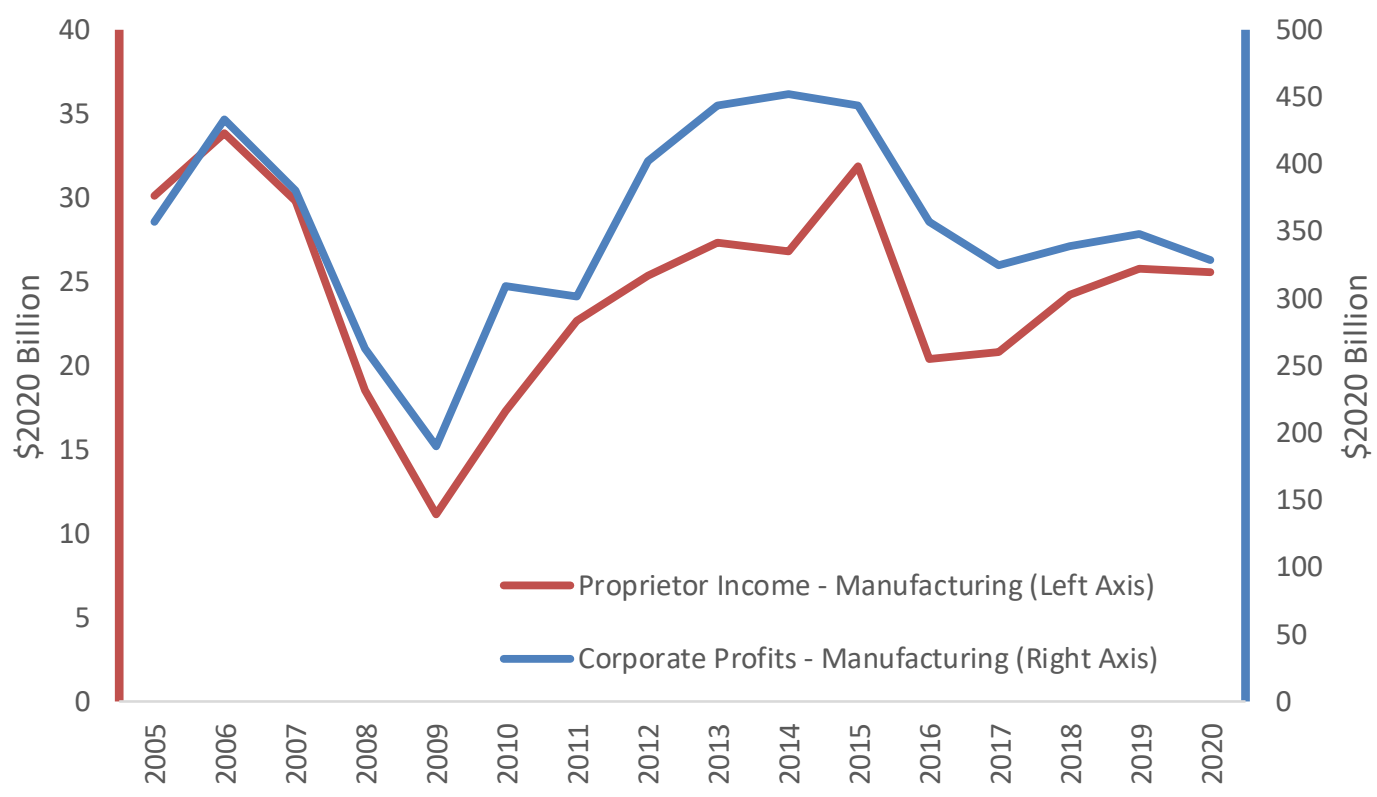

Figure 4.6: Profits for Corporations and Income for Proprietorships

Source: Bureau of Economic Analysis. (2021) Income and Employment by Industry. Table 6.16D. Corporate Profits by Industry and Table 6.12D. Nonfarm Proprietors' Income. https://apps.bea.gov/iTable/index nipa.cfm.

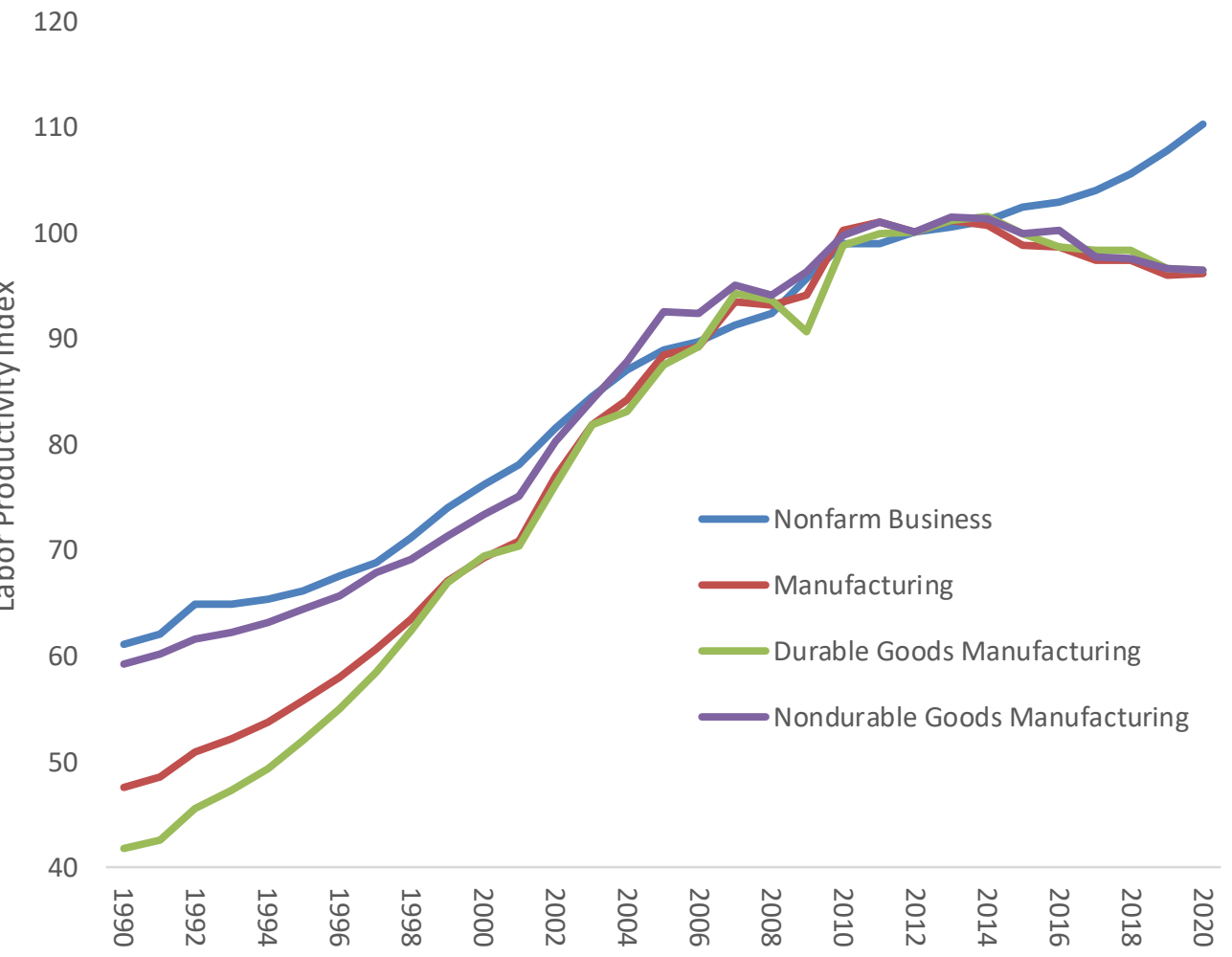

Figure 4.7: Manufacturing Labor Productivity Index (2012 Base Year $=100$ )

Source: Bureau of Labor Statistics. (2021) Productivity. https://www.bls.gov/mfp/ 


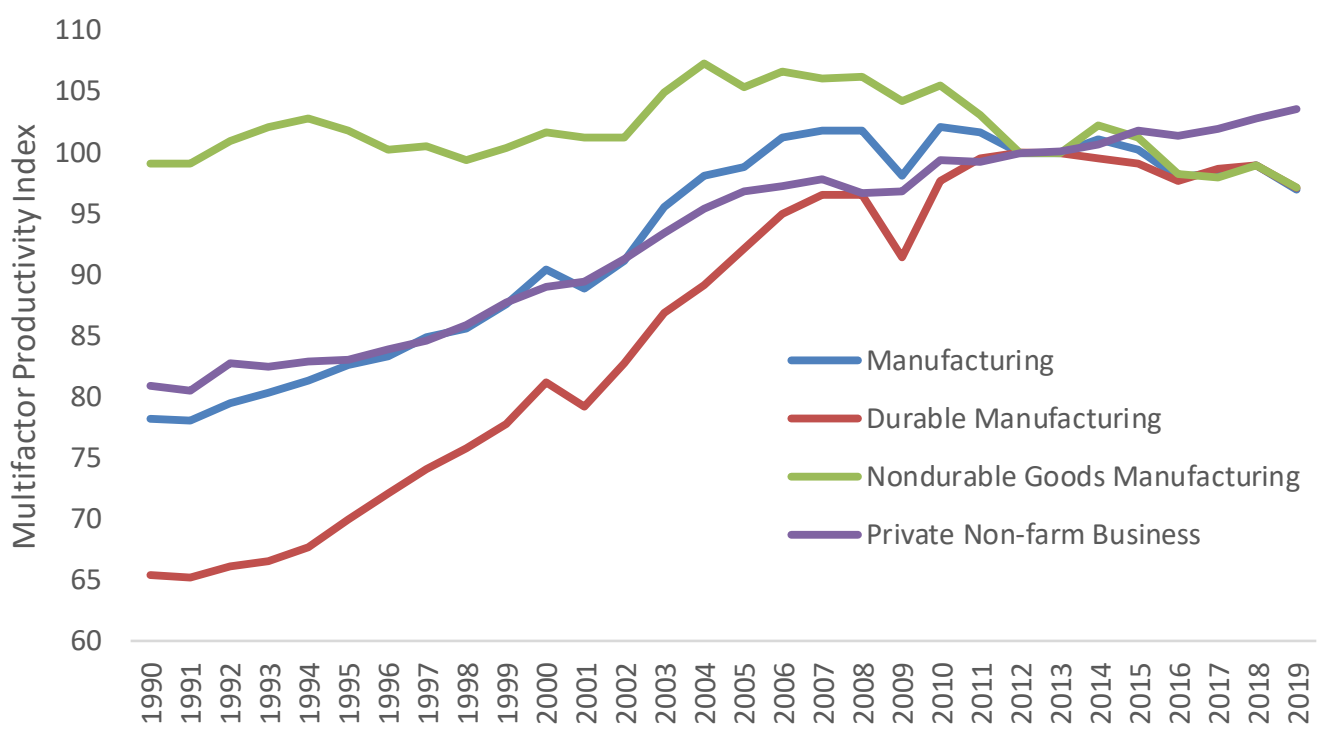

Figure 4.8: Manufacturing Multifactor Productivity Index (2012 Base Year = 100)

Source: Bureau of Labor Statistics. (2021) Productivity. https://www.bls.gov/mfp/

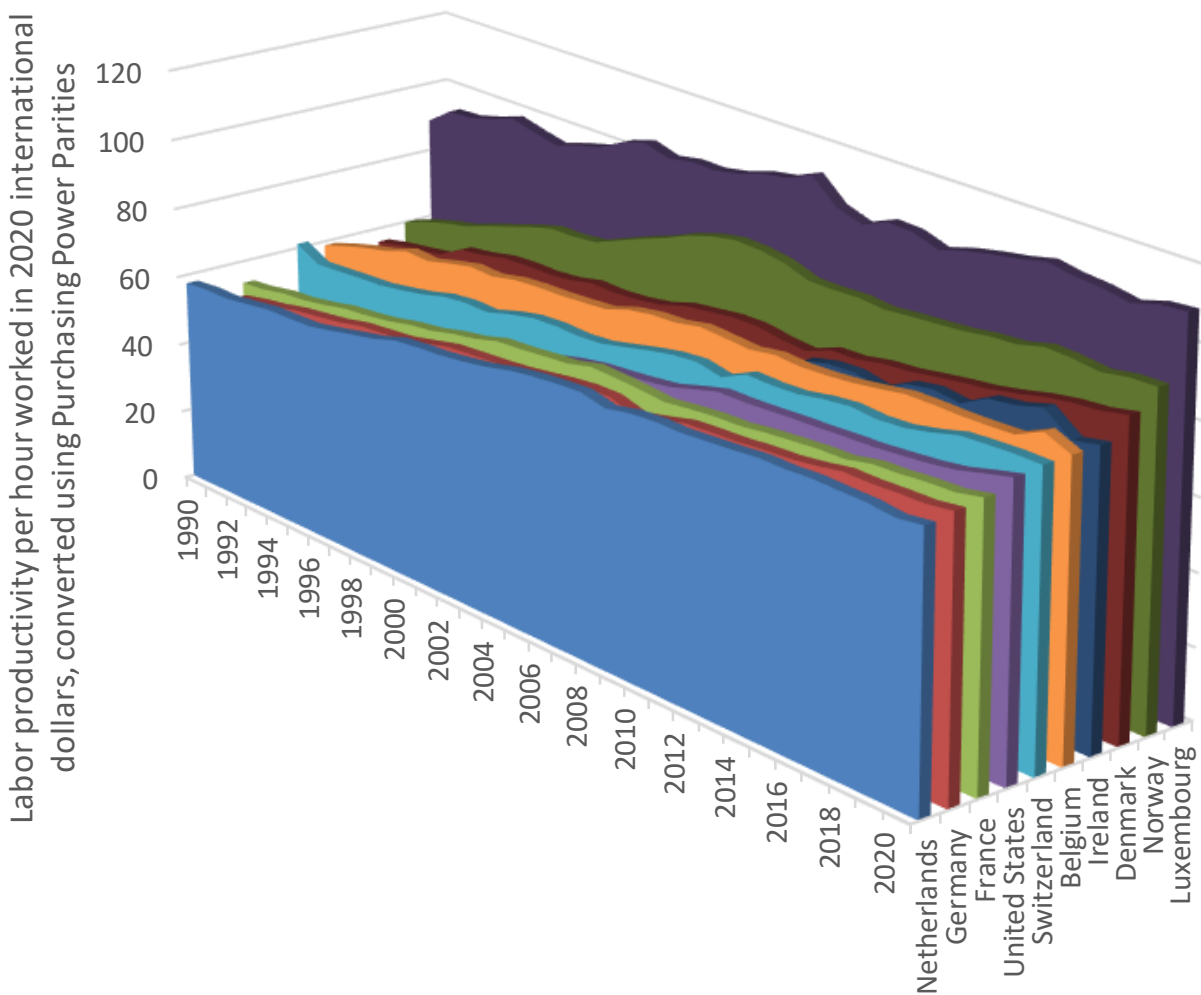

Figure 4.9: Output per Labor Hour (Top Ten Countries Out of 133)

Source: Conference Board. (2021) Total Economy Database: Output, Labor and Labor Productivity. https://www.conferenceboard.org/data/economydatabase/index.cfm?id=27762 


\section{Research, Innovation, and Factors for Doing Business}

Manufacturing goods involves not only physical production, but also design and innovation. Measuring and comparing innovation between countries is problematic, however, as there is no standard metric for measuring this activity. Four measures are often discussed regarding innovation: number of patent applications, research and development expenditures, number of researchers, and number of published journal articles. As seen in Figure 5.1, the U.S. ranked $4^{\text {th }}$ in 2019 in resident patent applications per million people, which puts it above the $95^{\text {th }}$ percentile among 138 countries. Using patent applications as a metric can be problematic though, as not all innovations are patented and some patents might not be considered innovation. The U.S. ranked $8^{\text {th }}$ in research and development expenditures as a percent of GDP in 2018, which puts it above the $85^{\text {th }}$ percentile (see Figure 5.2) among 75 nations. As seen in Figure 5.3, U.S. enterprise research and development expenditures in manufacturing increased between 2016 and 2017 and has a 5-year compound annual growth rate of $2.7 \%$ (not shown). However, as a percent of value added it decreased between 2016 and 2017. In terms of researchers per million people, the U.S. ranked $19^{\text {th }}$ in 2017 , putting it just above the $75^{\text {th }}$ percentile (see Figure 5.4). In journal articles per million people it ranked $22^{\text {nd }}$ in 2017 , and China had more articles than the U.S. (see Figure 5.5). ${ }^{30}$ Exports are also frequently seen as a measure of competitiveness. The U.S. was the second largest exporter, as seen in Figure 5.6.

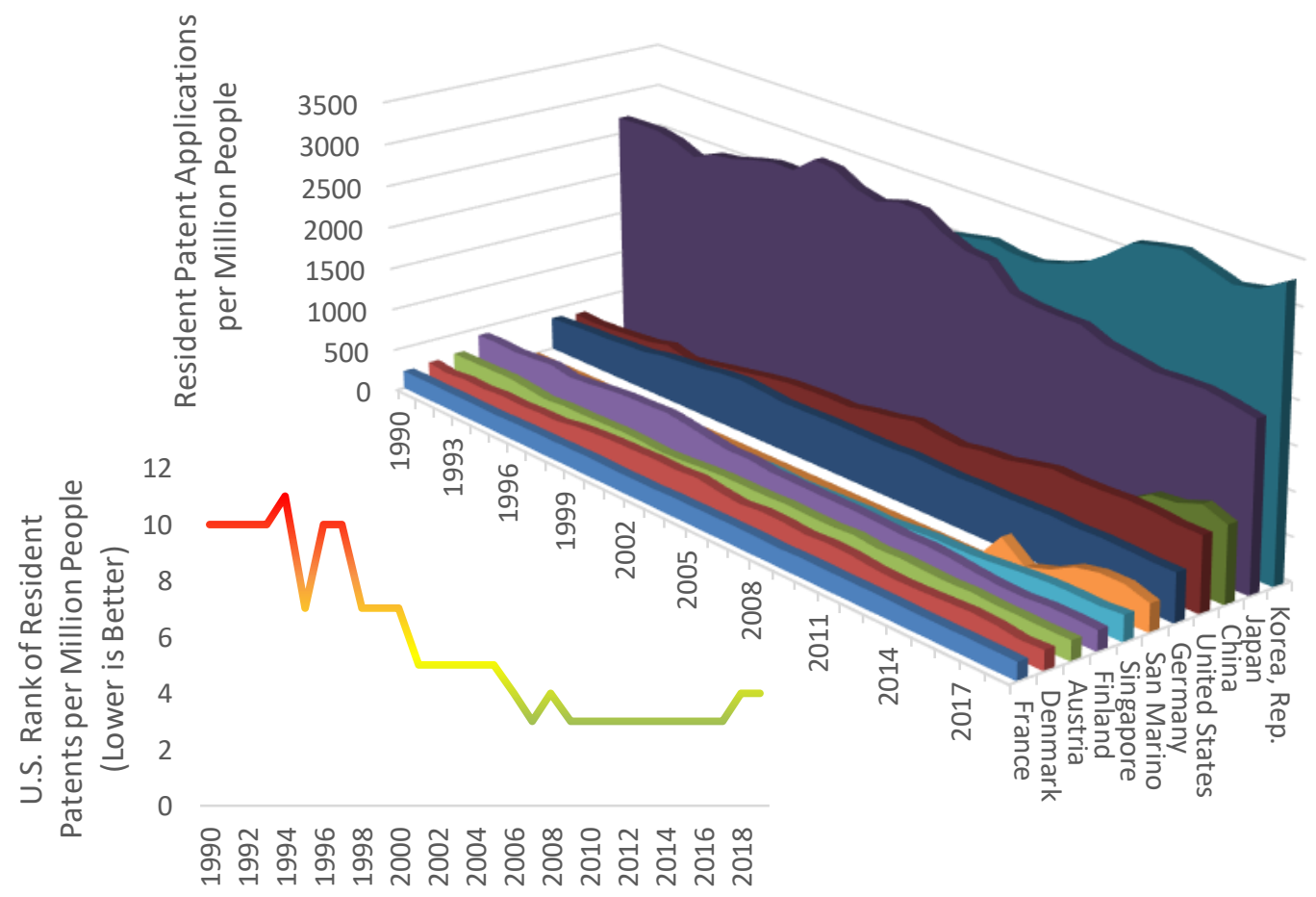

Figure 5.1: Patent Applications (Residents) per Million People, Top Ten (1990-2019)

World Bank. 2021. World Development Indicators. https://data.worldbank.org/products/wdi

\footnotetext{
${ }^{30}$ World Bank. 2021. World Development Indicators. http://data.worldbank.org/data-catalog/worlddevelopment-indicators
} 


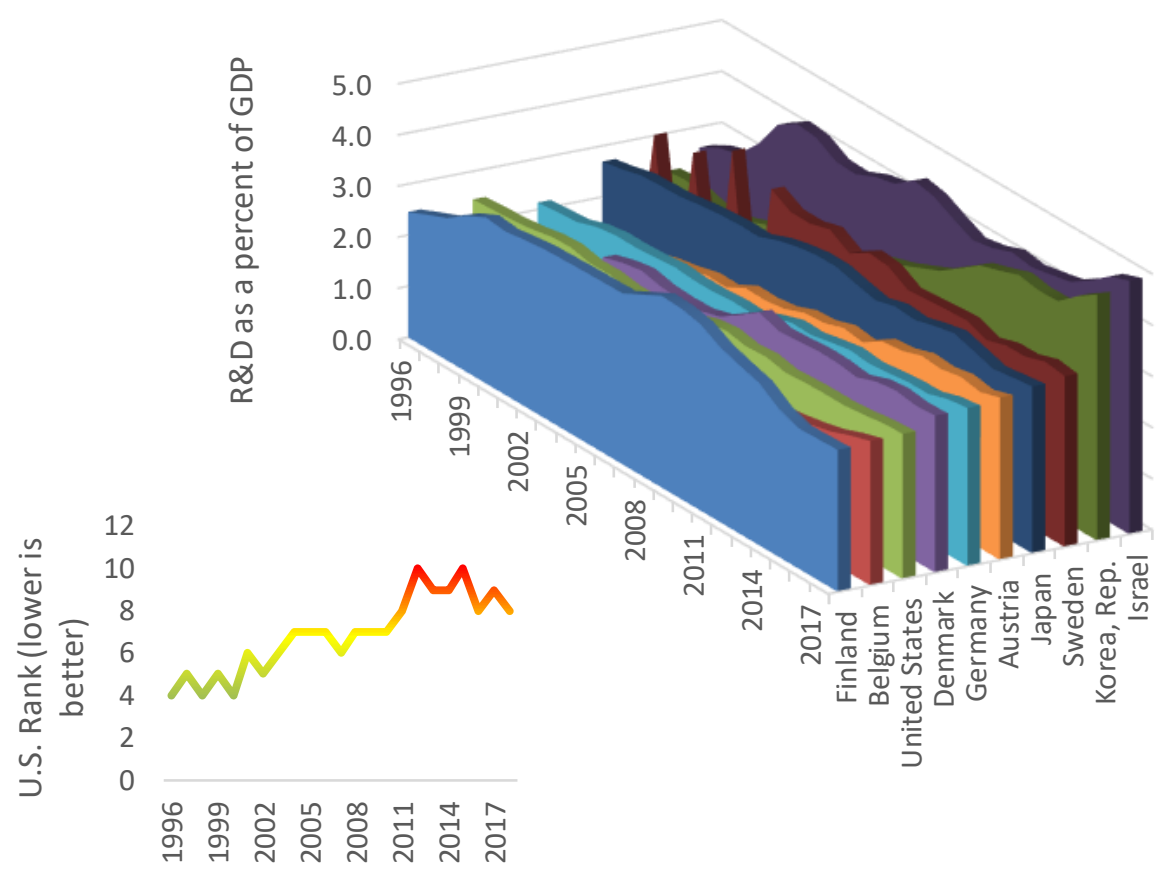

Figure 5.2: Research and Development Expenditures as a Percent of GDP

Source: World Bank. 2021. World Development Indicators. https://data.worldbank.org/products/wdi

* Missing data was interpolated

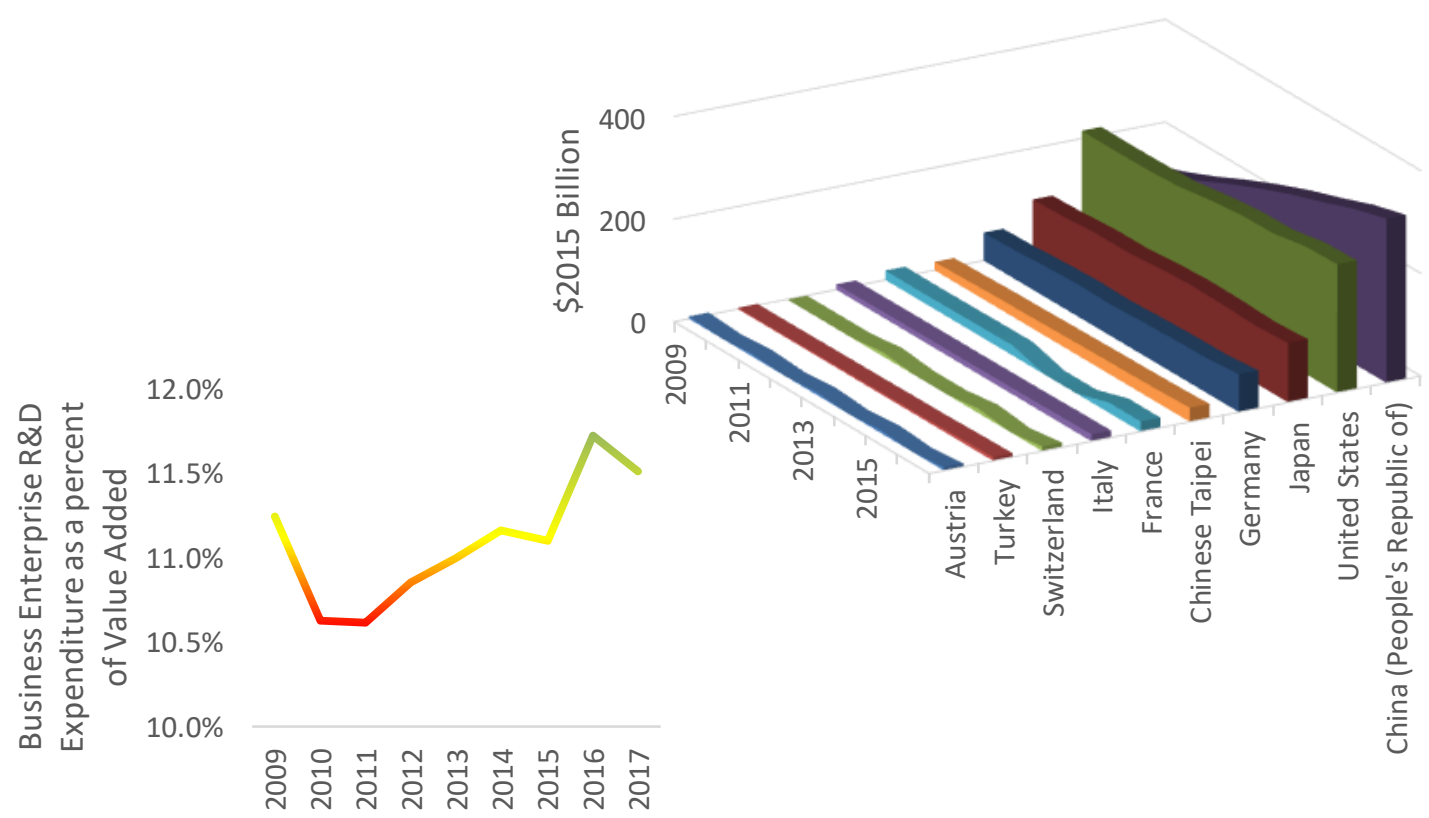

Figure 5.3: Manufacturing Enterprise Research and Development Expenditures

Source: OECD. (2019) Business Enterprise R-D Expenditure by Industry (ISIC 4). http://stats.oecd.org/\# United Nations Statistics Division. (2020). "National Accounts Main Aggregates Database."

http://unstats.un.org/unsd/snaama/Introduction.asp 
In addition to some of the previously mentioned metrics, a number of indices have been developed to assess national competitiveness. The IMD World Competitiveness Index provides insight into the U.S. innovation landscape. Figure 5.7 provides the U.S. ranking for 20 measures of competitiveness. This provides some indicators to identify opportunities for improvement in U.S. economic activity. In 2021, the U.S. ranked low in public finance, prices, societal framework, and international trade among other things. Overall, the U.S. ranked $10^{\text {th }}$ in competitiveness for conducting business. ${ }^{31}$

The 2016 Deloitte Global Manufacturing Competitiveness Index uses a survey of CEOs to rank countries based on their perception. The U.S. was ranked $2^{\text {nd }}$ out 40 nations with China being ranked $1^{\text {st }}$. High-cost labor, high corporate tax rates, and increasing investments outside of the U.S. were identified as challenges to the U.S. industry. Manufacturers indicated that companies were building high-tech factories in the U.S. due to rising labor costs in China, shipping costs, and low-cost shale gas. ${ }^{32}$ According to
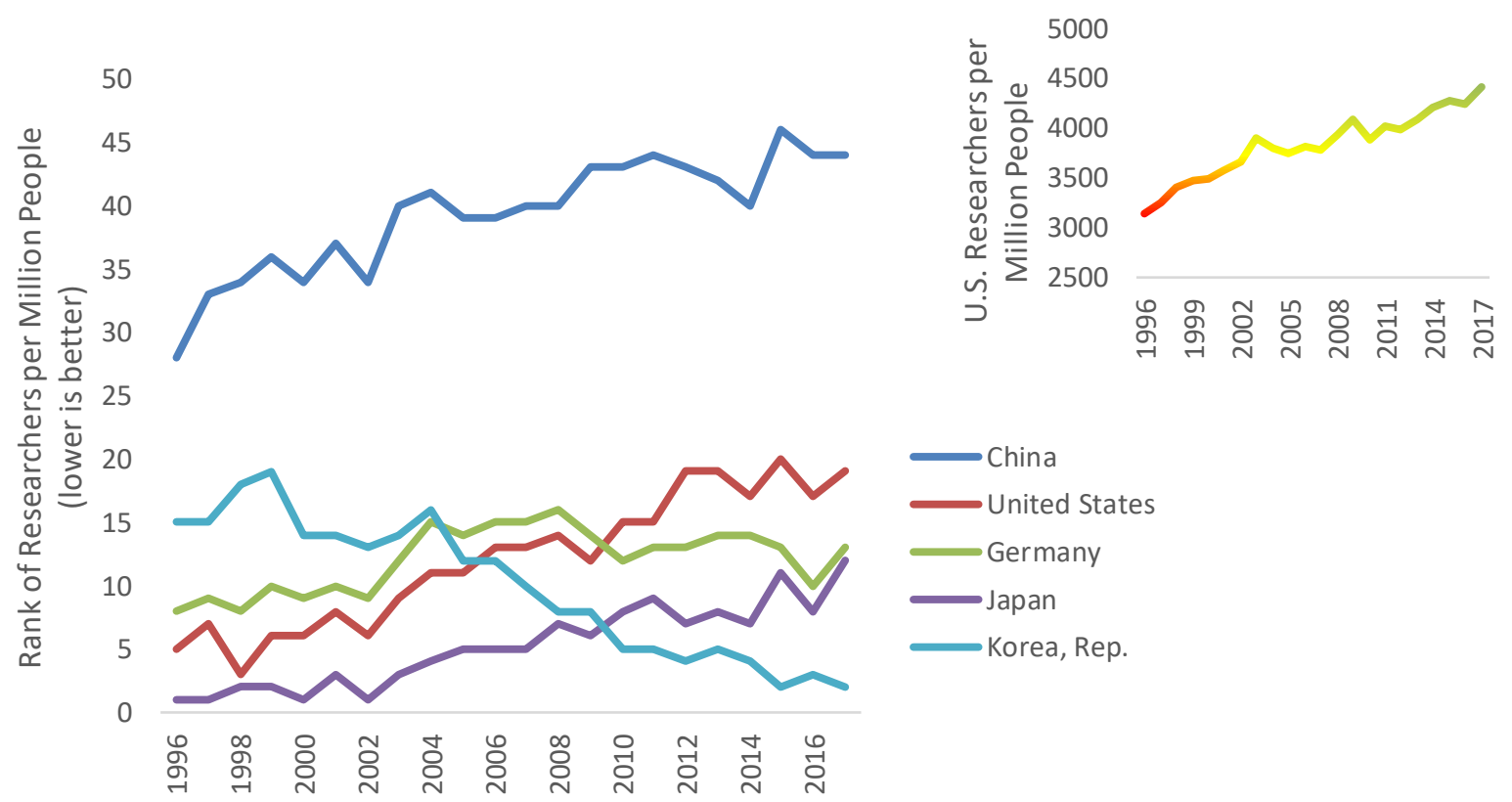

Figure 5.4: Researchers per Million People, Ranking

World Bank. 2021. World Development Indicators. https://data.worldbank.org/products/wdi

\footnotetext{
${ }^{31}$ IMD. (2021). IMD World Competitiveness Country Profile: U.S.

https://worldcompetitiveness.imd.org/countryprofile/US

32 Deloitte. (2016). 2016 Global Manufacturing Competitiveness Index.

http://www2.deloitte.com/content/dam/Deloitte/us/Documents/manufacturing/us-gmci.pdf
} 


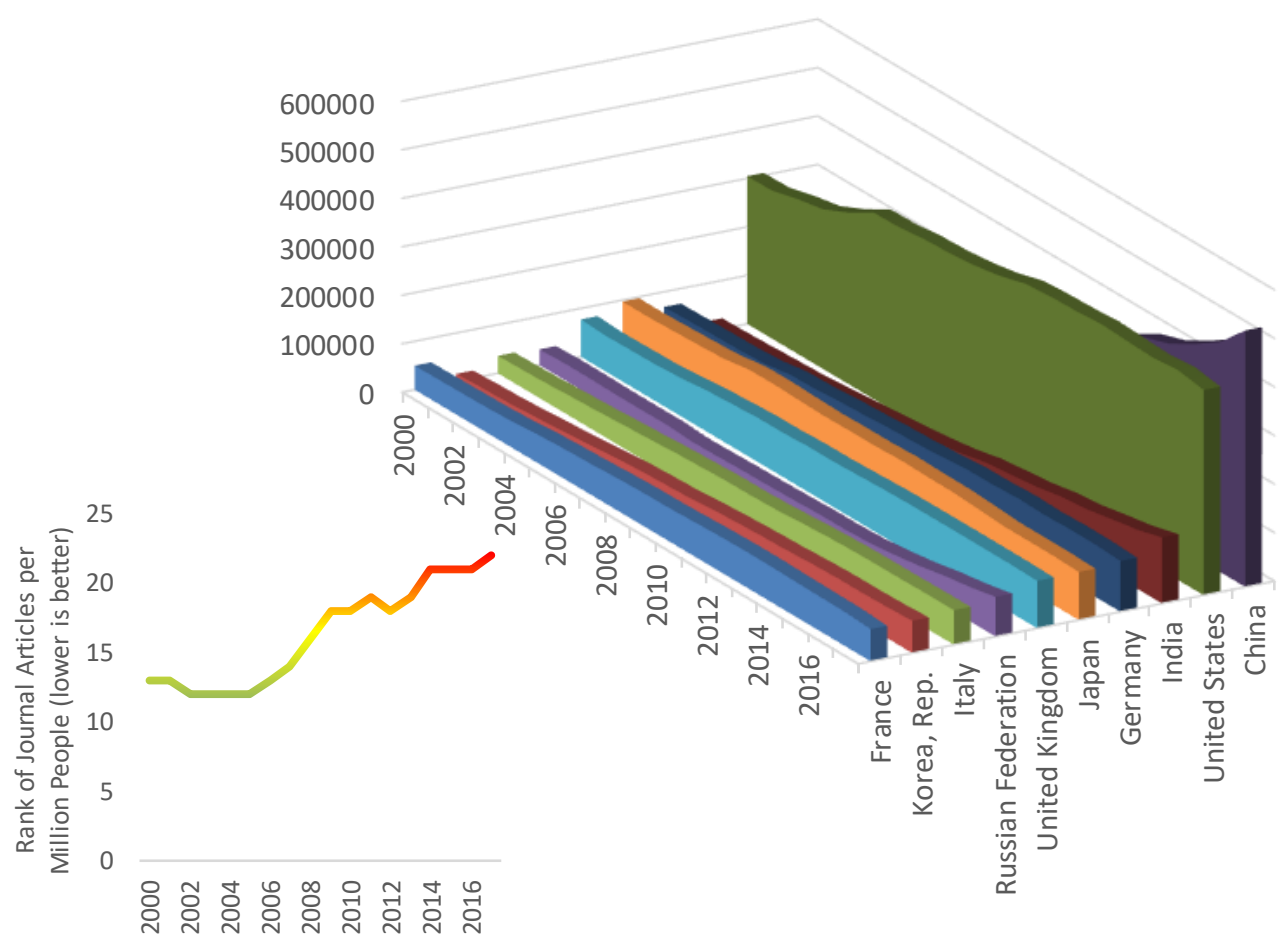

Figure 5.5: Journal Articles, Top 10 Countries

World Bank. 2020. World Development Indicators. https://data.worldbank.org/products/wdi

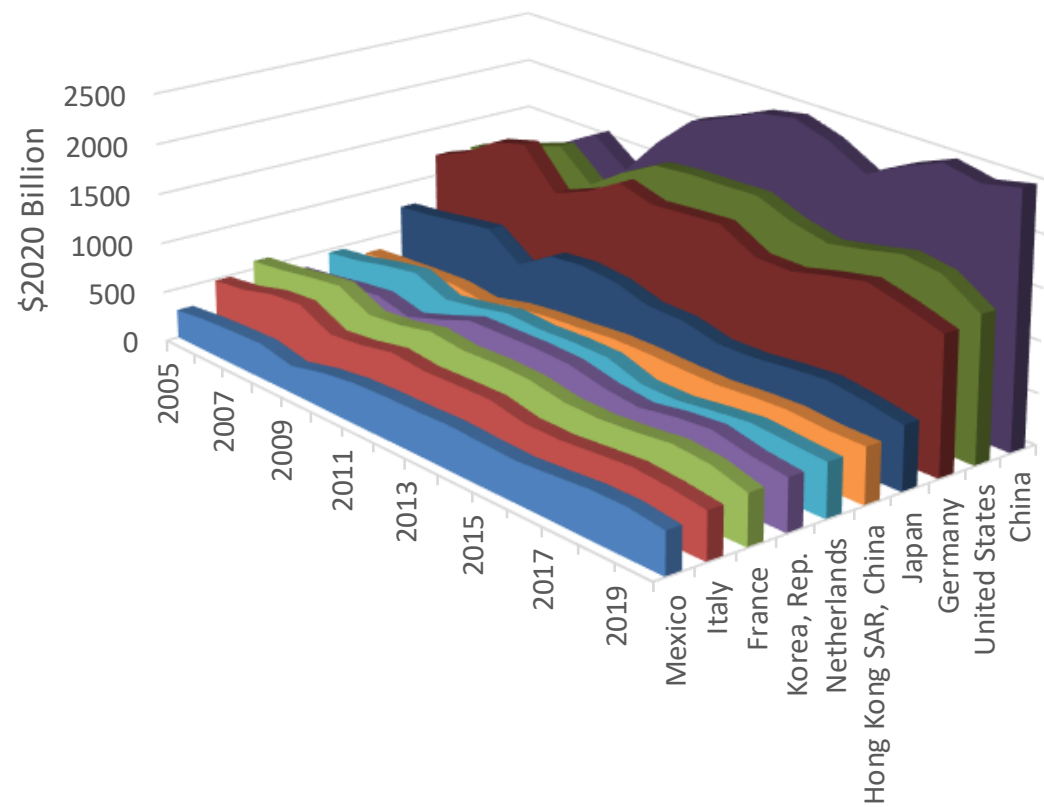

Figure 5.6: Goods Exports (BOP) of the Top Ten Exporters

World Bank. 2020. World Development Indicators. https://data.worldbank.org/products/wdi

NOTE: Adjusted using the Consumer Price Index for all consumers from the Bureau of Labor Statistics. 


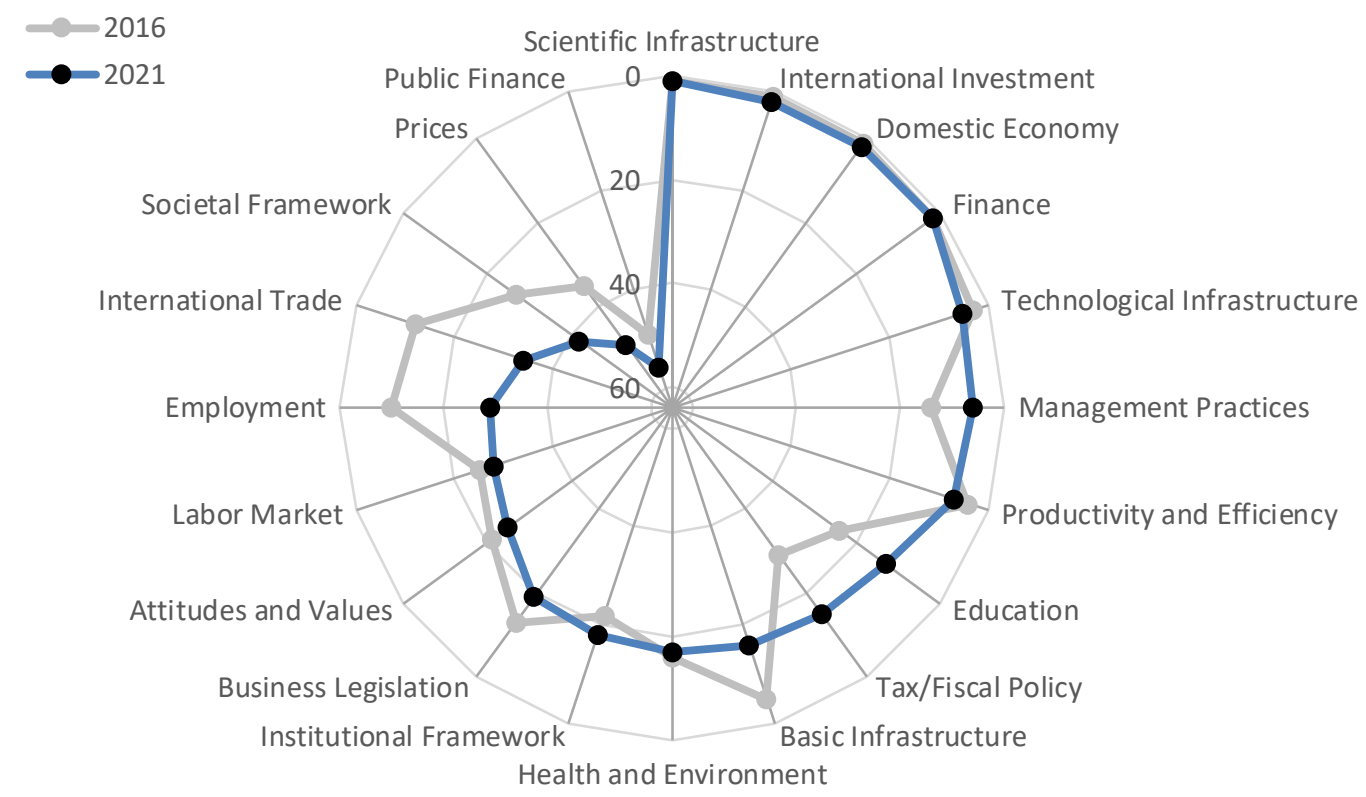

Figure 5.7: IMD World Competitiveness Rankings for the US: Lower is Better (i.e., a Rank of 1 is Better than a Rank of 64) - 64 countries ranked

the Deloitte Global Manufacturing Competitiveness Index, advantages to U.S. manufacturers included its technological prowess and size, productivity, and research support. China was ranked $1^{\text {st }}$ with advantages in raw material supply, advanced electronics, and increased research and development spending. China has challenges in innovation, slowing economic growth, productivity, and regulatory inefficiency.

The World Economic Forum's 2019 Global Competitiveness Report uses 12 items to assess the competitiveness of 141 economies, which includes the set of "institutions, policies and factors that determine a country's level of productivity." The U.S. was ranked $2^{\text {nd }}$ overall with various rankings in the 12 "pillars" that underly the ranking, as illustrated in Figure 5.8. Within the 12 "pillars," there were lower rankings in health, macroeconomic stability, and information/communication technology adoption. ${ }^{33}$ The index uses a set of 90 factors to produce the 12 items in Figure 5.8. A selection of those that are relevant to standards, technology, and information dissemination are presented in Table 5.1. Those that have poorer rankings might be opportunities for improvement. Among those selected in Table 5.1, the U.S. ranks below the $90^{\text {th }}$ percentile in both of the crime items, 2 of the 8 transport items, 6 of the 9 utility items, labor-health, 2 of the 9 human capital items, both barrier to entry items, and 2 of the 10 innovation items.

\footnotetext{
${ }^{33}$ World Economic Forum. (2019). The Global Competitiveness Report 2019. http://www3.weforum.org/docs/WEF_TheGlobalCompetitivenessReport2019.pdf
} 


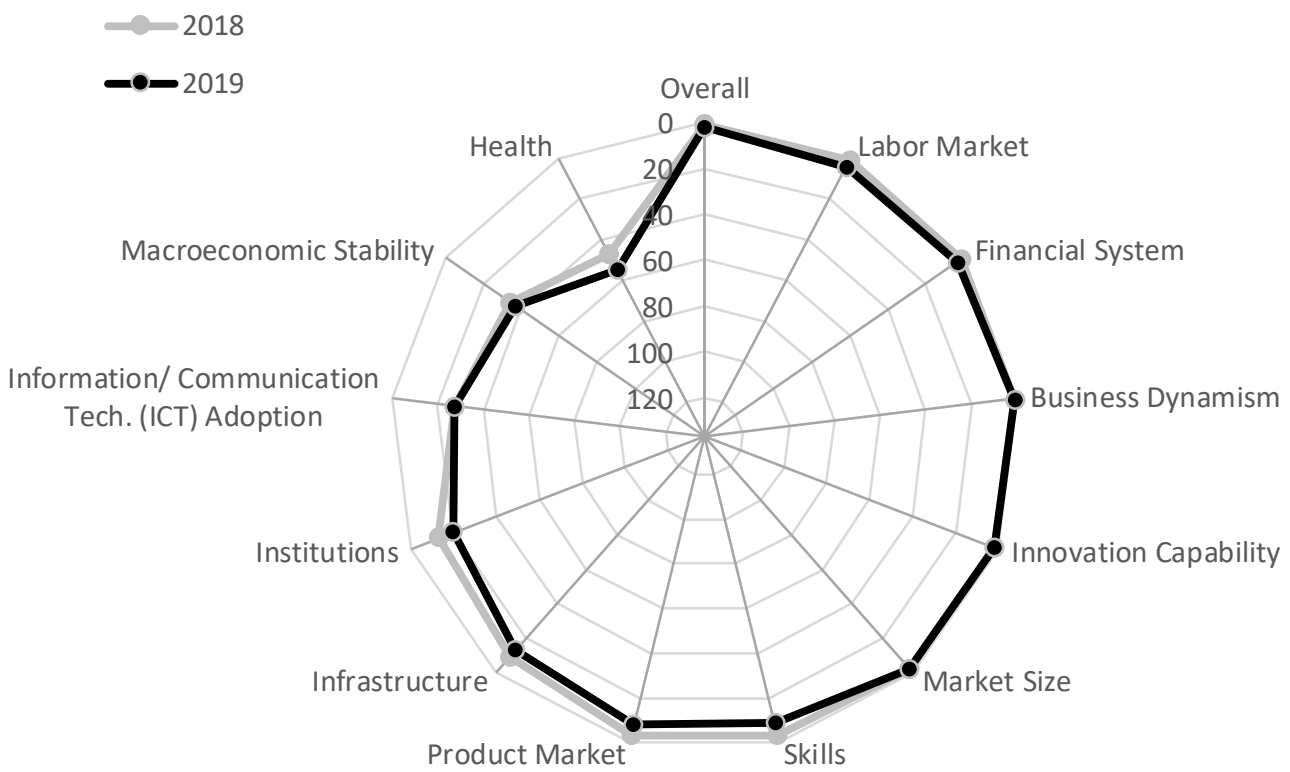

Figure 5.8: World Economic Forum 2019 Global Competitiveness Index: U.S. Pillar Rankings: Lower is Better

The Competitive Industrial Performance Index, published by the United Nations Industrial Development Organization, ranks 152 countries based on 3 dimensions: 1) capacity to produce and export manufactured goods; 2) technological deepening and upgrading; and 3) world impact. ${ }^{34}$ The U.S. ranked below the $90^{\text {th }}$ percentile on the first two dimensions and ranked $4^{\text {th }}$ overall, as seen in Table 5.2.

The Annual Survey of Entrepreneurs makes inquiries on U.S. entrepreneurs concerning the negative impacts of eight items:

- Access to financial capital

- Cost of financial capital

- Finding qualified labor

- Taxes

- Slow business or lost sales

- Late or nonpayment from customers

- Unpredictability of business conditions

- Changes or updates in technology

- Other

${ }^{34}$ United Nations Industrial Development Organization. (2021). Competitive Industrial Performance Report 2020. https://stat.unido.org/content/publications/competitive-industrial-performance-report-2020 
Table 5.1: World Economic Forum Competitiveness Index Indicators - Selection of those Relevant to Standards, Technology, and Information Dissemination Solutions, Rankings Out of 141 Countries (Lower is Better)

\begin{tabular}{|c|c|c|c|}
\hline Pillar & Component & US Rank & Application \\
\hline 1 & Organized crime & 69 & Crime \\
\hline 1 & Terrorism incidence & 83.3 & Crime \\
\hline 1 & Intellectual property protection & 12 & IP Protection \\
\hline 2 & Road connectivity index & 1 & Transport \\
\hline 2 & Quality of roads & $\square 17$ & Transport \\
\hline 2 & Railroad density (km of roads/square $\mathrm{km}$ ) & 48 & Transport \\
\hline 2 & Efficiency of train service & 12 & Transport \\
\hline 2 & Airport connectivity & 1 & Transport \\
\hline 2 & Efficiency of air transport services & 10 & Transport \\
\hline 2 & Liner shipping connectivity index & 】 & Transport \\
\hline 2 & Efficiency of seaport services & 10 & Transport \\
\hline 2 & Electrification rate (\% of population) & 2 & Utilities \\
\hline 2 & Electric power transmission and distribution losses (\% output) & 23 & Utilities \\
\hline 2 & Exposure to unsafe drinking water (\% of population) & $\square 14$ & Utilities \\
\hline 2 & Reliability of water supply & $\square 30$ & Utilities \\
\hline 3 & Mobile-cellular telephone subscriptions (per 100 people) & 54 & Utilities \\
\hline 3 & Mobile-broadband subscriptions (per 100 people) & 7 & Utilities \\
\hline 3 & Fixed-broadband internet subscriptions (per 100 people) & 18 & Utilities \\
\hline 3 & Fibre internet subscriptions (per 100 people) & 45 & Utilities \\
\hline 3 & Internet users (\% of population) & 26 & Utilities \\
\hline 5 & Healthy life expectancy & 54 & Labor - Health \\
\hline 6 & Mean years of schooling & 7 & Human Capital \\
\hline 6 & Extent of staff training & 6 & Human Capital \\
\hline 6 & Quality of vocational training & ] & Human Capital \\
\hline 6 & Skillset of graduates & 5 & Human Capital \\
\hline 6 & Digital skills among population & 12 & Human Capital \\
\hline 6 & Ease of finding skilled employees & 1 & Human Capital \\
\hline 6 & School life expectancy (expected years of schooling) & 30 & Human Capital \\
\hline 6 & Critical thinking in teaching & 9 & Human Capital \\
\hline 6 & Pupil-to-teacher ratio in primary education & 45 & Human Capital \\
\hline 11 & Cost of starting a business ( $\%$ GNI per capita) & 24 & Barriers to Entry \\
\hline 11 & Time to start a business (days) & 31 & Barriers to Entry \\
\hline 11 & Companies embracing disruptive ideas & 2 & Innovation \\
\hline 12 & State of cluster development & 2 & Innovation \\
\hline 12 & International co-inventions (applications/million people) & $\square 19$ & Innovation \\
\hline 12 & Multi-stakeholder collaboration & 2 & Innovation \\
\hline 12 & Scientific publications (H index) & 1 & Innovation \\
\hline 12 & Patent applications (per million people) & $\square 13$ & Innovation \\
\hline 12 & R\&D expenditures (\% of GDP) & $\square 11$ & Innovation \\
\hline 12 & Quality of research institutions & 1 & Innovation \\
\hline 12 & Buyer sophistication & 4 & Innovation \\
\hline 12 & Trademark applications (per million people) & 32 & Innovation \\
\hline
\end{tabular}

Pillars: 1) Institutions, 2) Infrastructure, 3) Information and communication technology adoption, 4) macroeconomic policy, 5) Health, 6) Skills, 7) Product market, 8) Labor market, 9) Financial system, 10) Market size, 11) Business dynamism, and 12) Innovation capability.

Applications: The application categories were developed for this report in order to identify items that might be relevant to manufacturing 
As seen in Figure 5.9, there are five items where more than a third of the firms indicated negative impacts. Among them were taxes, slow business or lost sales, unpredictability of business conditions, finding qualified labor, and government regulations. ${ }^{35}$

Table 5.2: Rankings from the Competitive Industrial Performance Index 2019, 152 Total Countries

\begin{tabular}{lcccc} 
& Overall & $\begin{array}{c}\text { Capacity to } \\
\text { produce and export } \\
\text { manufactured } \\
\text { goods }\end{array}$ & $\begin{array}{c}\text { Technological } \\
\text { deepening } \\
\text { and } \\
\text { upgrading }\end{array}$ & World Impact \\
\hline Germany & 1 & 5 & 6 & 3 \\
China & 2 & 47 & 9 & 1 \\
Republic of Korea & 3 & 12 & 2 & 5 \\
United States & 4 & 32 & 30 & 2 \\
Japan & 5 & 17 & 7 & 4 \\
\hline
\end{tabular}

Source: United Nations Industrial Development Organization. (2021). Competitive Industrial Performance Report 2020. https://stat.unido.org/content/publications/competitive-industrial-performance-report-2020 f

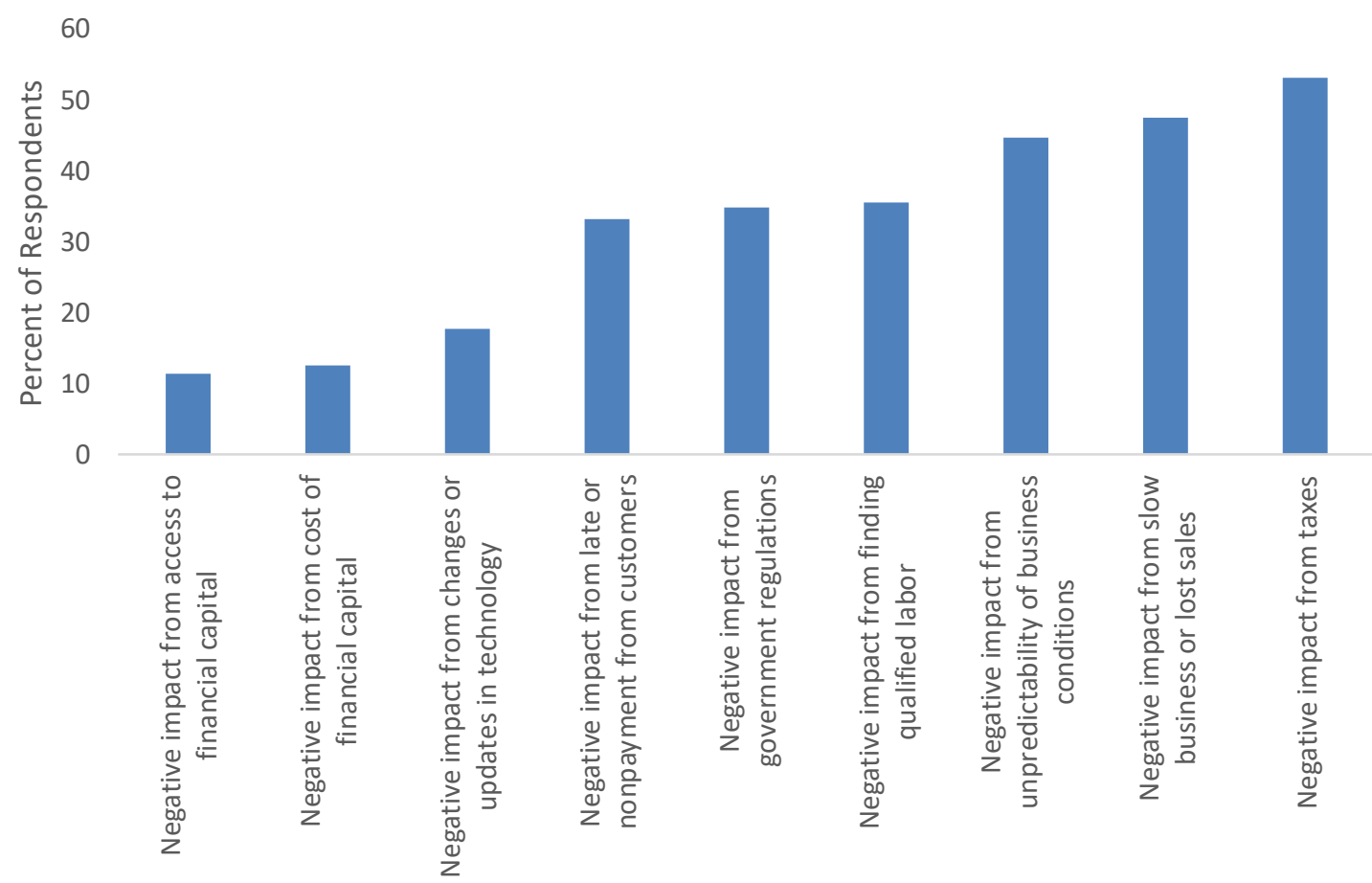

Figure 5.9: Factors Impacting U.S. Business (Annual Survey of Entrepreneurs), 2016

${ }^{35}$ U.S. Census Bureau. (2019) Annual Survey of Entrepreneurs. https://www.census.gov/programssurveys/ase.html 


\section{Discussion}

This report provides an overview of the U.S. manufacturing industry. There are 3 aspects of U.S. manufacturing that are considered: (1) how the U.S. industry compares to other countries, (2) the trends in the domestic industry, and (3) the industry trends compared to those in other countries. The U.S. remains a major manufacturing nation; however, other countries are rising rapidly. Manufacturing in the U.S. was significantly impacted by the 2000 's recession and the 2020 economy.

The U.S. accounts for $16.6 \%$ of global manufacturing, according to the United Nations Statistics Division National Accounts Main Aggregates Database, making it the second largest. Compound real (i.e., controlling for inflation) annual growth in the U.S. between 1994 and 2019 was $2.4 \%$, which places the U.S. below the $50^{\text {th }}$ percentile. The compound annual growth for the U.S. between 2014 and 2019 was $1.9 \%$. This puts the U.S. above the $25^{\text {th }}$ percentile but above Canada and Germany among others. In terms of subsectors of manufacturing, the U.S. ranks $1^{\text {st }}$ in 7 industries out of 16 total while China was the largest for the other industries, as reported in OECD data.

In 2020, there was an estimated $\$ 2269.2$ billion in manufacturing value added in constant 2020 dollars. Using 2012 input-output data adjusted to 2019 dollars, there is an estimated $\$ 4278$ billion, including direct and indirect value added, associated with U.S.

manufacturing. In 2019, the U.S. imported approximately $14.7 \%$ of its intermediate goods, according to BEA data. Discrete technology products account for $36 \%$ of manufacturing value added, according to BEA data.

During the late 2000's recession, manufacturing value added declined more than total U.S. GDP, creating a persistent gap. The result is that first quarter GDP in 2021 is $29.2 \%$ above its 2005 level while manufacturing is at $21.5 \%$ above its 2005 level. As of January 2020, employment was still $12.9 \%$ below its 2005 level. In the initial stages of the pandemic, employment dropped to $19.9 \%$ below 2005 levels, which is near the same levels as the late 2000's recession. Employment is still below pre-pandemic levels; however, there are a substantial number of job openings in manufacturing. If these openings were filled, it would raise employment above pre-pandemic levels and would equate to a $7 \%$ increase in manufacturing employment. 


\section{Bibliography}

Allwood, J. M. \& Cullen, J. M. (2012). Sustainable Materials with Both Eyes Open. Cambridge Ltd. 185. http://www.withbotheyesopen.com/

Block, Fred L and Matthew R. Keller. State of Innovation: The U.S. Government's Role in Technology Development. New York, NY; Taylor \& Francis; 2016.

Bureau of Economic Analysis. (2021). "Income and Employment by Industry." Table 6.16D. Corporate Profits by Industry and Table 6.12D. Nonfarm Proprietors' Income. https://apps.bea.gov/iTable/index_nipa.cfm.

Bureau of Economic Analysis. (2021) "Fixed Assets Accounts Tables." https://apps.bea.gov/iTable/iTable.cfm?ReqID $=10 \&$ step $=2$

Bureau of Economic Analysis. (2021). Input-Output Accounts Data. https://www.bea.gov/industry/input-output-accounts-data

Bureau of Economic Analysis. (2021). "Industry Economic Accounts Data." http://www.bea.gov/iTable/index_industry_gdpIndy.cfm

Bureau of Economic Analysis. (1997). BEA's Chain Indexes, Time Series, and Measures of Long-Term Economic Growth.

https://www.bea.gov/scb/account_articles/national/0597od/maintext.htm

Bureau of Labor Statistics. (2017). Beyond the Numbers: Productivity. https://www.bls.gov/opub/btn/volume-6/pdf/understanding-the-labor-productivity-andcompensation-gap.pdf

Bureau of Labor Statistics. (2021). Census of Fatal Occupational Injuries. "Industry by Event or Exposure." http://stats.bls.gov/iif/oshcfoil.htm

Bureau of Labor Statistics. Consumer Price Index. (2021) https://www.bls.gov/cpi/data.htm

Bureau of Labor Statistics. (2021). Current Employment Statistics. http://www.bls.gov/ces/home.htm

Bureau of Labor Statistics. (2021). Current Population Survey. "Table 17: Employed Persons by Industry, Sex, Race, and Occupation." http://www.bls.gov/cps

Bureau of Labor Statistics. (2021). Injuries, Illness, and Fatalities Program. http://www.bls.gov/iif/

Bureau of Labor Statistics. (2021). National Compensation Survey. http://www.bls.gov/ncs/

Bureau of Labor Statistics. (2021). Productivity. https://www.bls.gov/mfp/ 
Bureau of Labor Statistics. (2021) Job Openings and Labor Turnover Survey. https://www.bls.gov/jlt/

Callen, Tim. (2007). PPP Versus the Market: Which Weight Matters? Finance and Development. Vol 44 number 1. http://www.imf.org/external/pubs/ft/fandd/2007/03/basics.htm

Conference Board. (2020). Total Economy Database: Output, Labor and Labor Productivity. https://www.conferenceboard.org/data/economydatabase/index.cfm?id=27762

Deloitte. (2016). Global Manufacturing Competitiveness Index. http://www2.deloitte.com/content/dam/Deloitte/us/Documents/manufacturing/usgmci.pdf

Dornbusch, Rudiger, Stanley Fischer, and Richard Startz. (2000). Macroeconomics. 8th ed. London, UK: McGraw-Hill.

Fenton, M. D. (2001). "Iron and Steel Recycling in the United States in 1998." Report 01224. U.S. Geological Survey: 3. https://pubs.usgs.gov/of/2001/of01-224/

Hopp, Wallace J. and Mark L. Spearman. (2008). Factory Physics. Third Edition. Waveland Press, Long Grove, IL.

IMD. (2021). IMD World Competitiveness Country Profile: U.S. https://worldcompetitiveness.imd.org/countryprofile/US

Lee, Yung-Tsun Tina, Frank H. Riddick, and Björn Johan Ingemar Hohansson (2011). "Core Manufacturing Simulation Data - A Manufacturing Simulation Integration Standard: Overview and Case Studies." International Journal of Computer Integrated Manufacturing. vol 24 issue 8: 689-709.

National Institute of Standards and Technology. (2018). "NIST General Information." http://www.nist.gov/public_affairs/general_information.cfm

National Science Foundation. (2004). "On the Origins of Google." https://www.nsf.gov/discoveries/disc_summ.jsp?cntn_id=100660

OECD. (2019). Business Enterprise R-D Expenditure by Industry (ISIC 4). http://stats.oecd.org/\#

OECD. (2020). STAN Input-Output Tables. https://stats.oecd.org/

Robert D. Niehaus, Inc. (2014). Reassessing the Economic Impacts of the International Standard for the Exchange of Product Model Data (STEP) on the U.S. Transportation Equipment Manufacturing Industry. 
Tabikh, Mohamad. (2014). "Downtime Cost and Reduction Analysis: Survey Results." Master Thesis. KPP321. Mälardalen University. http://www.diva-

portal.org/smash/get/diva2:757534/FULLTEXT01.pdf

Tassey Gregory. (2010) "Rationales and Mechanisms for Revitalizing U.S.

Manufacturing R\&D Strategies." Journal of Technology Transfer. 35. 283-333.

Thomas, Douglas S. (2012). The Current State and Recent Trends of the U.S.

Manufacturing Industry. NIST Special Publication 1142.

http://nvlpubs.nist.gov/nistpubs/SpecialPublications/NIST.SP.1142.pdf

Thomas, Douglas S. and Anand Kandaswamy. (2017) "Identifying high resource consumption areas of assembly-centric manufacturing in the United States." Journal of Technology Transfer. https://link.springer.com/article/10.1007\%2Fs10961-017-9577-9

Thomas, Douglas, Anand Kandaswamy, and Joshua Kneifel. (2017). "Identifying High Resource Consumption Supply Chain Points: A Case Study in Automobile Production." 25th International Input-Output Conference. Atlantic City, NJ.

https://www.iioa.org/conferences/25th/papers.html

Thomas, Douglas. (2018). "The Effect of Flow Time on Productivity and Production." National Institute of Standards and Technology. Advanced Manufacturing Series 100-25. https://nvlpubs.nist.gov/nistpubs/ams/NIST.AMS.100-25.pdf

Thomas, Douglas. (2020). Manufacturing Cost Guide. https://www.nist.gov/servicesresources/software/manufacturing-cost-guide

United Nations Industrial Development Organization. (2021). Competitive Industrial Performance Report 2020. https://stat.unido.org/content/publications/competitiveindustrial-performance-report-2020

United Nations Statistics Division. (2020). "National Accounts Main Aggregates Database." http://unstats.un.org/unsd/snaama/Introduction.asp

U.S. Census Bureau. (2019). Annual Survey of Entrepreneurs. https://www.census.gov/programs-surveys/ase.html

U.S. Census Bureau. (2019). Manufacturers' Shipments, Inventories, and Orders. https://www.census.gov/manufacturing/m3/historical_data/index.html

U.S. Census Bureau. (2020) 2017 Economic Census.

https://www.census.gov/data/tables/2017/econ/economic-census/naics-sector-31-33.html

U.S. Census Bureau. (2021). "Annual Survey of Manufactures.”

https://www.census.gov/programs-surveys/asm/data/tables.html

Wessner, C.W. and Wolff A.W. (2012). Rising to the Challenge: U.S. Innovation Policy for the Global Economy. National Research Council (US) Committee on Comparative 
National Innovation Policies: Best Practice for the 21st Century. Washington (DC):

National Academies Press (US). http://www.ncbi.nlm.nih.gov/books/NBK100307/

World Bank. (2021). World Development Indicators. http://data.worldbank.org/datacatalog/world-development-indicators

World Economic Forum. (2019). The Global Competitiveness Report 2018.

http://www3.weforum.org/docs/GCR2018/05FullReport/TheGlobalCompetitivenessRepo rt2018.pdf 